SAND94-2331

Unlimited Release

November 1994
Distribution

Category UC-126

\title{
Strategic Petroleum Reserve (SPR) Additional Geologic Site Characterization Studies Bryan Mound Salt Dome, Texas
}

\author{
James T. Neal \\ Sandia National Laboratories \\ Albuquerque, New Mexico \\ Thomas R. Magorian, Consultant \\ Amherst, New York \\ Saddam Ahmad \\ Acres International Corporation \\ Amherst, New York
}

Prepared by Sandia National Laboratories

Albuquerque, NM 87185 and Livermore, CA 94550

for the U. S. DOE under Contract DE-ACO4-94AL85000

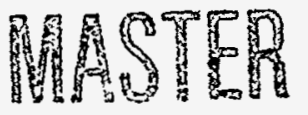




\begin{abstract}
This report revises and updates the original geologic site characterization report that was published in 1980. Some of the topics covered in the earlier report were provisional and it is now practicable to reexamine them some 15 years later, using new or revised geotechnical data and that obtained from SPR cavern operations, which involves 16 new caverns.

Revised structure maps and sections show interpretative differences as compared with the 1980 report and more definition in the dome shape and caprock structural contours, especially a major southeast-northwest trending anomalous zone. The original interpretation was of westward tilt of the dome, but this revision shows a tilt to the southeast, consistent with other gravity and seismic data. This interpretation refines the evaluation of additional cavern space, by adding more salt buffer and allowing several more caverns. Additional storage space is constrained on this nearly full dome because of low-lying peripheral wetlands, but $60 \mathrm{MMBBL}$ or more of additional volume could be gained in six or more new caverns.

Subsidence values at Bryan Mound are among the lowest in the SPR system, averaging about $11 \mathrm{~mm} / \mathrm{yr}(0.4 \mathrm{in} / \mathrm{yr})$, but measurement and interpretation issues persist, as observed values are about the same as survey measurement accuracy. Periodic, temporary flooding is a continuing threat because of the coastal proximity and because peripheral portions of the site are at elevations less than $15 \mathrm{ft}$. This threat may increase slightly as future subsidence lowers the surface, but the amount is apt to be small. Caprock integrity may be affected by structural features, especially the faulting associated with anomalous zones. Injection wells have not been used extensively at Bryan Mound, but could be a practicable solution to future brine disposal needs.

Environmental issues center on the areas of low elevation that are below 15 feet above mean sea level: the coastal proximity and lowland environment combined with the potential for flooding create conditions that require continuing surveillance. Prior sulfur mining has resulted in residual high temperature and corrosive groundwater in the caprock and may have contributed to several casing failures. Natural seismicity has continued as predicted with periodic, minor temblors causing very minor local damage to surface buildings where occurring. Predicted peak horizontal accelerations are sufficiently low so as to cause no damage to mined underground openings such as SPR storage caverns.
\end{abstract}




\section{DISCLAIMER}

This report was prepared as an account of work sponsored by an agency of the United States Government. Neither the United States Government nor any agency thereof, nor any of their employees, make any warranty, express or implied, or assumes any legal liability or responsibility for the accuracy, completeness, or usefulness of any information, apparatus, product, or process disclosed, or represents that its use would not infringe privately owned rights. Reference herein to any specific commercial product, process, or service by trade name, trademark, manufacturer, or otherwise does not necessarily constitute or imply its endorsement, recommendation, or favoring by the United States Government or any agency thereof. The views and opinions of authors expressed herein do not necessarily state or reflect those of the United States Government or any agency thereof. 


\section{DISCLAIMER}

Portions of this document may be illegible in electronic image products. Images are produced from the best available original document. 


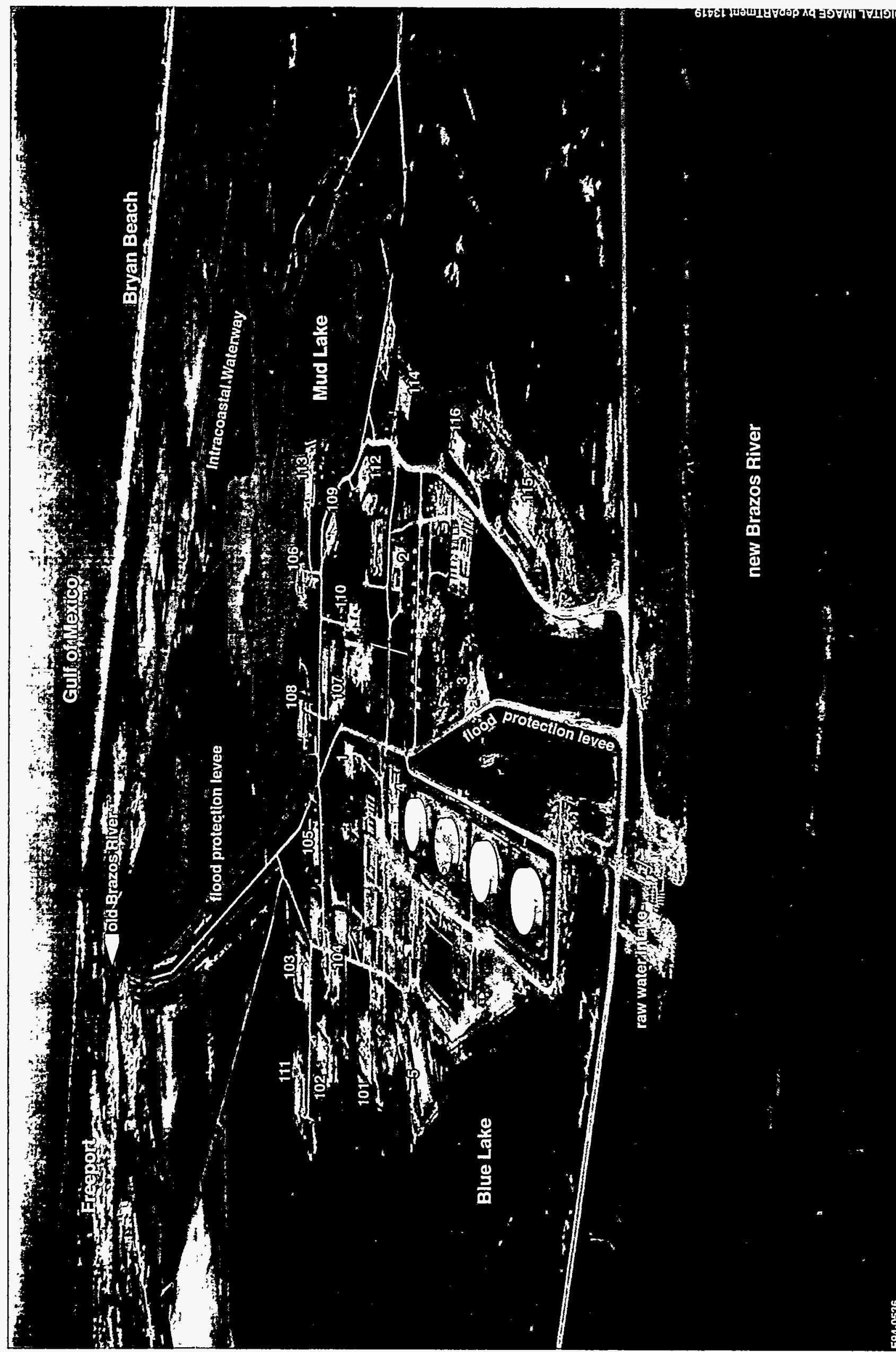

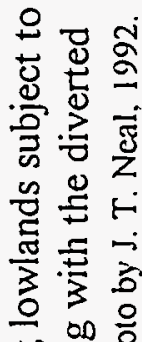

엠영

등 음

豆

옹

등

उ

ठิ

蛋

包

E

ए

\&

0

吕

등 응

昰氠

도을

릉

.

ㅊ

品

눙

옹

文

$\simeq 3$

พิ

x

$\bullet \stackrel{0}{\circ}$

氙吉焉

응

긍워

뜌 을

을

$\sum_{0} 0$

통

लि

क्षे

¿ क ल

造 전

을 异 


\section{TABLE OF CONTENTS}

\section{Strategic Petroleum Reserve (SPR) \\ Additional Geologic Site Characterization Studies \\ Bryan Mound Salt Dome, Texas}

EXECUTIVE SUMMARY.

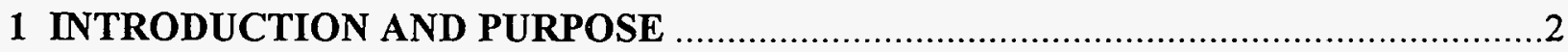

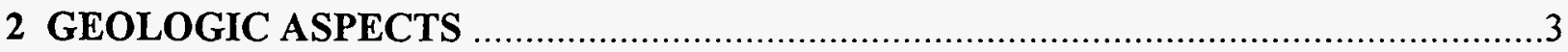

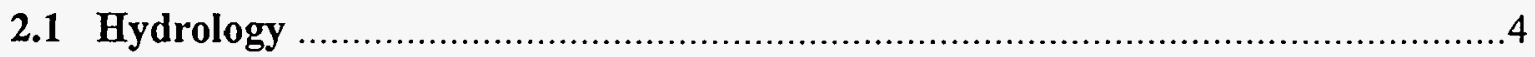

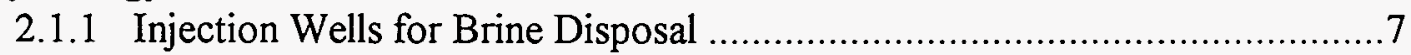

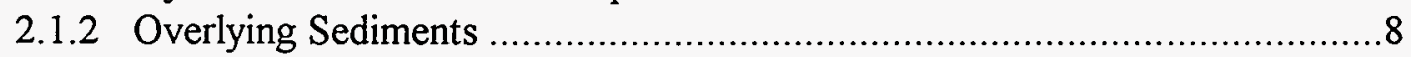

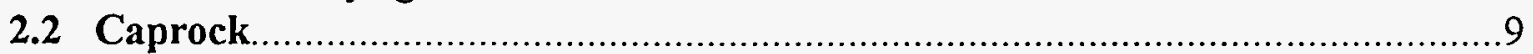

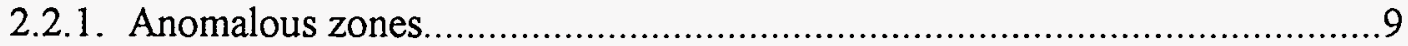

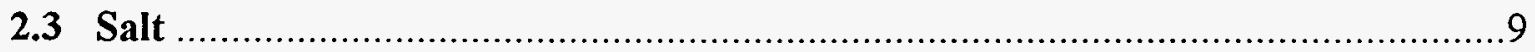

2.3.1 Salt Nature and Internal Structure ..................................................

2.3.2 Shape of Salt Stock and Overhang Geometry .........................................13

2.3.3 Salt Stock External Structure .............................................................20

2.3.4 Shale Sheath and Convergence of Sediments on Dome Flanks ..................24

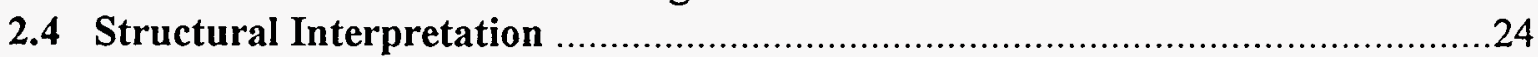

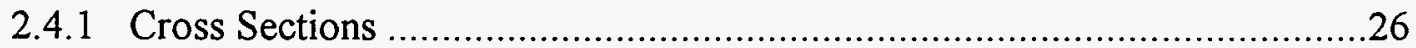

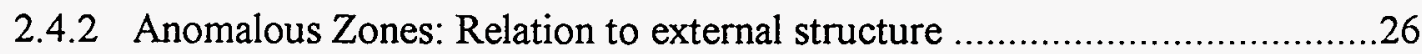

2.4.3 Correlation of geologic features with gassy caverns ..................................35

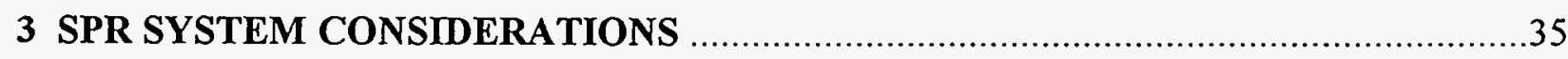

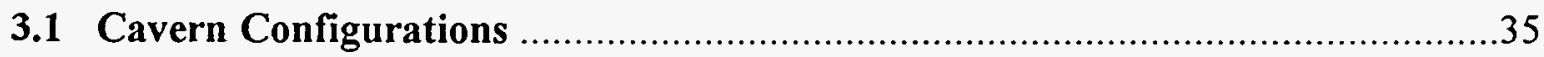

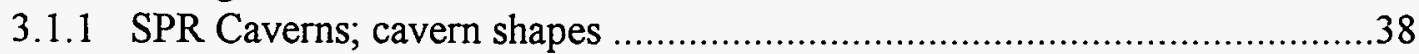

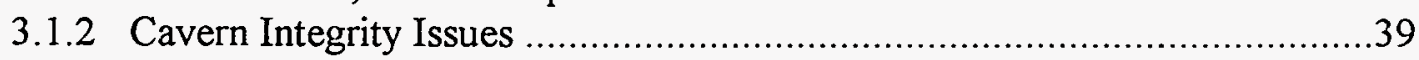

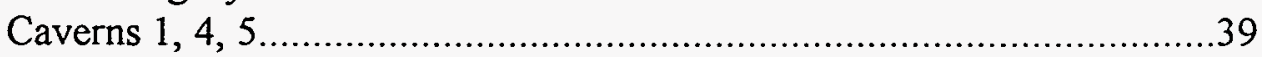

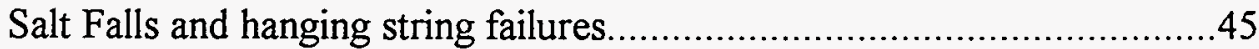

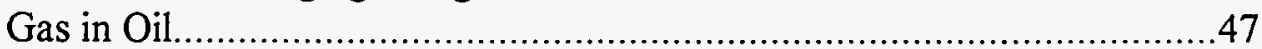

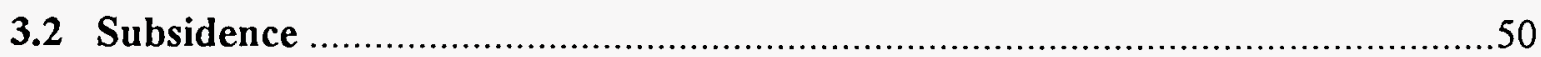

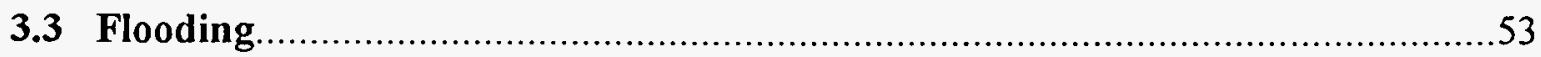

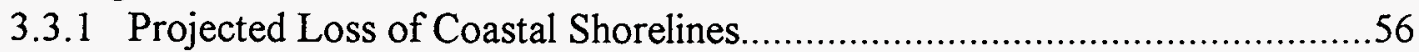

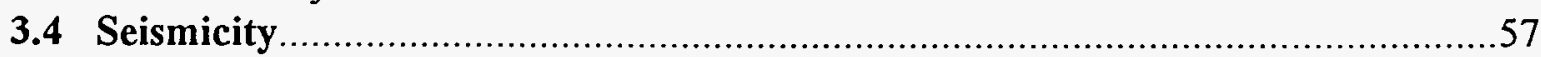

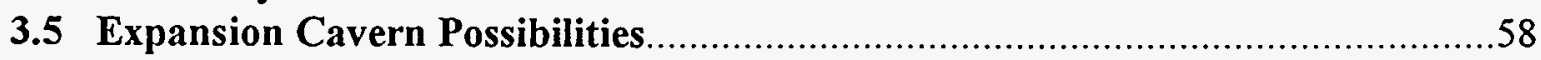


6 REFERENCES

\section{APPENDICES}
A Regional Geology
A $1-10$
B Seismicity and Faulting Potential
B $1-9$
C Bryan Mound Well Data
D Salt Photographs and Thin Sections
D $1-4$

\section{LIST OF FIGURES}

Frontispiece Bryan Mound Aerial View, Showing Coastal Proximity and Hydrography .....iii-iv

1 Well Locations and Cross Section Index $5-6$

2 Contours, Top of Caprock $11-12$

3a, b Salt Stock Internal Structure, through Caverns 106-110 13,14

4a Isometric view, showing shape of dome 16

4 b Contours, Top of Salt $17-18$

5 Residual Gravity Values over Salt Dome.

6 Contours, Top of Miocene .23

7 Contours, Top of Anahuac Shale .25

8 Cross Section 1, East-West, through Caverns 5, 4, 1, 108 $27-28$ 
9 Cross Section 2, North-South, through Caverns 110, 1, 104

10 Cross Section 3, Southwest-Northeast, through Caverns 115, 114, 2, 1, 105, 103 ......31-32

11 Cross Section 4, Northwest-Southeast, through Caverns 106, 107, 1, 104, 101 .........33-34

12 Salt Dome Cutaway View, Showing Distribution of Caverns in Southeast Quadrant ....37

13 Strategic Petroleum Reserve Caverns (Composite Views) 40,41

14 Cavern Isometric Profiles: 42,43

15 Flood Zone Map, from Revised FEMA Analysis, 1993 .55

16 Expansion Cavern Possibilities 59

\section{LIST OF TABLES}

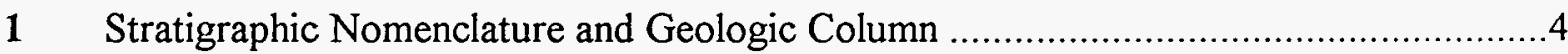

$2 \quad$ Geotechnical Data; Strategic Petroleum Reserve Caverns ............................................36

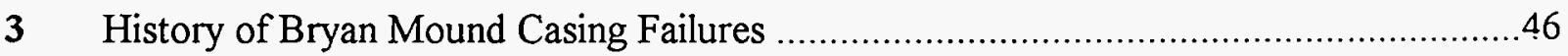

4 Correlation of Salt Falls with Numbers of Wells and Chimneys .................................48

5 Elevation Change at Selected Subsidence Stations: 1982-1993 …….........................52

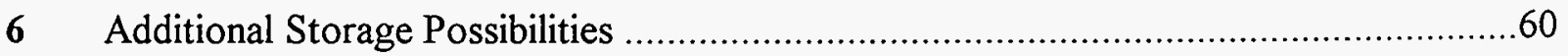

vii-viii 


\section{EXECUTIVE SUMMARY}

This revision and update to the initial 1980 geological site characterization has relied on some 15 years operating history of the SPR, as well as a more complete understanding of salt dome storage and all that it entails.

The shape of the Bryan Mound salt stock is modified somewhat from the original interpretation, with a very cylindrical overall shape having steep overhangs on the north, east, and south sides and a localized bulge or nose on the east. This revised interpretation allows more buffer space for the existing caverns, or alternatively, the possible expansion space for some $60 \mathrm{MMBBL}$ equivalent cavern volume. However, this additional space is on the present dome periphery, at areas of low elevation and containing Blue and Mud Lakes.

Structural features within the salt stock and external to the dome include at least two intersecting anomalous zones (probable shear zones), dividing the stock into some four individual lobes or spines. These features probably control permeability zones for gas migration within the salt stock, which may be controlling differential intrusion of gas into caverns containing SPR oil. This conceptualization has not been verified, mainly because of the lack of conclusive data.

Salt falls have been a continuing problem within half (ten) of the SPR caverns, accounting for 31 of 37 incidents of lost casing. The exact nature of these occurrences is obscure, largely because of the lack of conclusive evidence. No geological correlations have been adequately explained, even though there appears to be a localized clustering of occurrences in half of the total caverns.

Subsidence is the lowest of all the SPR sites, even though the total cavern volume is nearly the same as West Hackberry with a rate nearly six times larger. The explanation lies in much lower laboratory salt creep rates, slightly shallower caverns, and possibly a smaller salt stock which effectively may restrain large scale dome deformations, including subsidence.

Flooding and seismicity risks are very low and are unchanged, but the validation of these potential threats is better established. The overall appraisal for safe storage at Bryan Mound has not been altered; however, confidence in the geologic interpretation is substantially increased. 


\section{INTRODUCTION AND PURPOSE}

Bryan Mound contains the most oil storage volume of the SPR sites, with a capacity of 226 million barrels contained in sixteen new caverns and four caverns acquired from the former owner, of which Cavern 5 is the largest in the SPR system. The Bryan Mound dome is much smaller than either the West Hackberry or Weeks Island domes.

The initial geological characterization of the Bryan Mound salt dome was conducted by D'Appolonia Consulting Engineers, Inc. in 1979-80 [Hogan et al., 1980]. Refinements to the original report are now possible, because of new information gained in the intervening years, and because of some thirteen years operating history by SPR. This report thus provides an update of data gathered and a rethinking of the previous geotechnical interpretations.

The regional geologic interpretation has changed relatively little, but new geologic understanding of salt tectonics is revolutionizing current thinking, including exploration for oil in the Gulf of Mexico Basin. The dome has had relatively meager study over the years because of the virtual lack of oil production; thus the structural control and interpretation (especially the relation of dome shape to geopressure) necessary to develop detailed interpretations of external geometry was constrained. This information is still less than at many domes, including all of the other SPR domes.

Caprock conditions have been a continuing concern because of the relatively small thickness and residual thermal conditions created from sulfur mining sixty some years ago. Caprock faulting such as that occurring at neighboring Stratton Ridge has not been noted at Bryan Mound.

Salt contours have been modified, as the reevaluation of earlier data suggest nuances occur in the overhang geometry. A protective shale sheath, similar to West Hackberry and Weeks Island, has been recognized and mapped. The structural interpretation is modified from that in the 1980 report; the refinements show intricacies that had not been recognized previously. Although the new understanding of salt tectonics in the Gulf of Mexico basin has altered traditional concepts, this probably will have 
little effect relative to storage applications at Bryan Mound.

Sixteen new SPR caverns have been leached and oil has been infilled; Cavern 3 was plugged and abandoned. Caverns have performed essentially as predicted with respect to maintaining mechanical integrity. However, apparent salt falls have been a recurring problem, with more than 30 incidents of lost casing reported since 1982. Gas-inoil has become an issue as gas quantities in some caverns are sufficiently high to require degassing prior to shipping.

The generally low elevation off of the center of the dome (under $15 \mathrm{ft}$ ) makes periodic flooding a continuing concern, and subsidence resulting from cavern creep closure an ongoing issue. Some ten years of survey data are evaluated, with a view toward forecasting future trends.

Finally, several environmental conditions are considered. A reassessment of hazards identified in the earlier characterization was conducted; DOE now requires that projects of this size and importance be updated at least every ten years. Hurricane threats are virtually unchanged, and revised FEMA flood maps show few changes that would affect Bryan Mound. Seismicity is also unchanged, but the interpretation of the threat has been revised slightly with the introduction of new data.

\section{GEOLOGIC ASPECTS}

Numerous refinements in the understanding of Gulf Coast geology have been made in the past 15 years; these are summarized in Appendix A , Bryan Mound Regional Geologic History, and mentioned at various places in the text. Significantly, SPR storage integrity is not affected other than very indirectly, and then in only minor ways. Well control is tabulated in Appendix C and depicted on Figure 1, which also shows locations of the Geologic Cross Sections. Stratigraphic nomenclature and the geologic column are listed at Table 1. 


\subsection{Hydrology}

No revisions of significance are required that would change the original 1980 hydrologic characterization, as few new data were obtained, nor did major hydrologic alteration occur during the intervening time.
The Chicot Aquifer consists of Pleistocene sands and basal gravel extending over the caprock. The upper Chicot consists of shallow fresh water Recent and Wisconsinequivalent sands of the Brazos Delta down to depths of 270 to 320 feet off the dome to the west.

\section{Table 1 Bryan Mound Stratigraphic Correlation Chart}

$\underline{\text { Unit }}$

Holocene

Pleistocene

Beaumont

Lissie

Montgomery

Bentley

Lafayette

Pliocene

Miocene

Goliad
Symbol

MO

LS (lower Lissie) mud

PL

MI

sand
Lithology

alluvium

marine clay

sand and gravel

sand and mud

sand (Bigenerina A)

shale

sand (Bigenerina B)

shale

sand (Textularia $L$ )

shale

sand (Bigenerina 2)

shale

Bigenerina humblei - - - UNCONFORMITY

sand (Cristellaria I)

shale

sand (Cibicides opima)

$\begin{array}{ll}\text { AB } & \text { shale } \\ \text { RL } & \text { deltaic sands }\end{array}$

$\begin{array}{ll}\text { AB } & \text { shale } \\ \text { RL } & \text { deltaic sands }\end{array}$

DR shale F geopressured shale ${ }^{*}$ and turbidite sand

Frio

* $\mathrm{P}$ on cross-sections (Figures 8-11) indicates geopressure, marked by reduced resistivity 


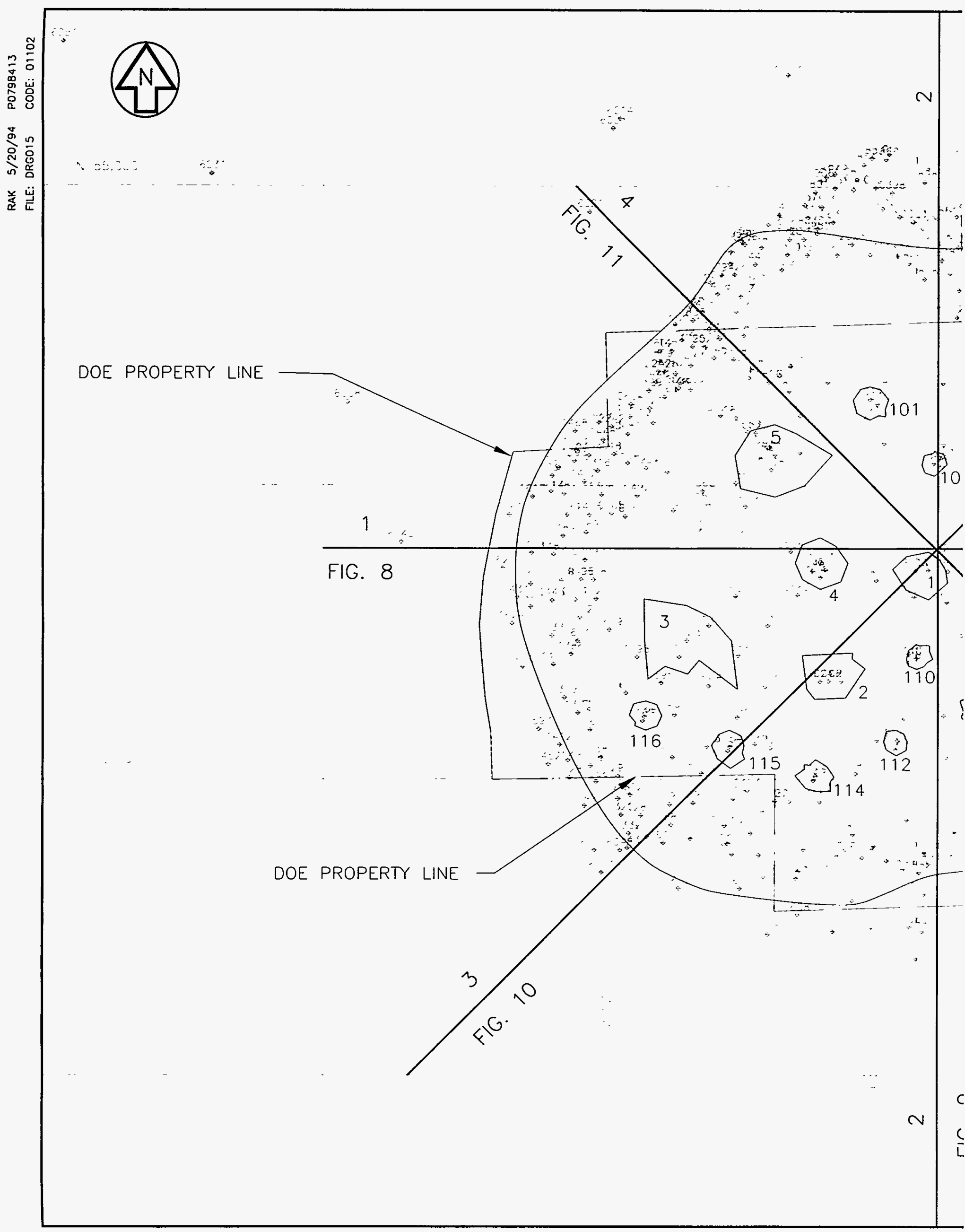


Only the uppermost of these sands, shallower than $100 \mathrm{ft}$, is fresh on the top of the dome (with a normal sand resistivity greater than $20 \mathrm{ohm}$-meters), being presently recharged from the diverted Brazos River. The remaining upper Chicot sands are brackish on the dome and nearby on the flank in its hydrologic shadow eastward and toward the coast. The DOE brine disposal wells and the Greenbrier well encountered freshwater sand to a depth of 260 feet in the upper Chicot. Further east in the Dow plant area, the deepest freshwater sand extends only to a depth of 200 feet, although the rest of the upper Chicot to a depth of 300 feet is only slightly brackish.

The lower Chicot Aquifer, including all of the Lissie sands, is brackish throughout the area and the primary source of industrial water. The caprock above the sulfurproducing zone is highly fractured and permeable, and the water is quite saline and corrosive, being fully-saturated at the top of the salt stock.

The caprock drapes over the outer edge of the salt and provides a source of brine flowing into the Evangeline Aquifer, the Pliocene sands on the flanks of the dome. Salinity in the Evangeline Aquifer decreases gradually updip, away from the salt stock, outside of the area of this characterization. These beds provide the deeper industrial water supply of the Freeport area; their permeability is discussed in the following section on brine disposal wells.

The deeper surrounding Miocene sediments, occasionally referred to as the Burkeville Aquifer, are all salt-saturated near the dome. They underlie the outer edge of the caprock and are in contact with the salt stock.

\subsubsection{Injection Wells for Brine Disposal}

Pliocene Injection Zones: The saline zone with the maximum hydraulic transmissivity is the thick sand and gravel at the base of the Pliocene, found at a depth of $1950 \mathrm{ft}$ in the original disposal area east of the dome(no longer being used). It is a pointbar gravel, the oldest deposited by the Brazos-Colorado Delta.

Each gravel bar is approximately $100 \mathrm{ft}$ thick, and the normal double ox-bow sequence is overlain by clean reworked sands. A 25-ft thick sand with some 10 darcy-feet transmissivity occurs in a middle mud and silt. An upper sand with a 100-foot pointbar is overlain by a massive 30 -foot sand with 70 darcy-feet transmissivity and a clean 
20-foot sand at the top. These beds persist in detail around the entire dome.

The total 500-foot interval contains 375 feet of sand and gravel with point (local) permeability as high as 5-6 darcies east of the dome. The total transmissivity observed at the disposal site is on the order of 170 darcyfeet, as estimated from the logs run in 1978 when cores were taken only in the Miocene.

Although the basal Pliocene gravel thins toward the dome, the overlying 350 feet of Pliocene silt, mud and marine Buliminella clay do not, providing a continuous seal for fresh-water aquifer protection. The dip is very gentle and to the east, away from the dome. Near the old Brazos channel, the spreading underground brine flow turns southeast and flows offshore where sand continuity can be demonstrated beyond the Tenneco Block 382S well, an identical section in two Mobil Block 382S gas wells (producing from deeper sands) and on across the wide continental shelf.

\section{Miocene Injection Zones: The next-} most promising zone is the Goliad sand at a depth of 2650 to 4000 feet: five permeable sands total some 100 darcy-feet of transmissivity. Most of this formation injectivity, some 70 darcy-feet, is in the 2800 -feet (depth) sand, apparently a delta-mouth bar, perhaps an early marine expression of the Brazos-Colorado delta. This zone could be completed concurrently with the Pliocene.

The few cores taken in the rest of the Goliad are muddy, marine sands. The first disposal well completed in this zone was a failure, mostly due to the drilling mud used in setting the screen.

The lower Miocene Oakville sands have some 20 darcy-feet of transmissivity between 5300 and 6800 feet depth. They are faulted at least 100 feet in wells 2 and $2 B$. This may be the fault with 300 feet of cutout in the Dow-Fee well to the northwest. Most of the wells closer to the dome drilled by Freeport-McMoran, Texaco, Exxon, Tenneco, Homestake and their predecessors are faulted. By staying in the Goliad and shallower, above the middle Miocene Lagarto shale which buries these faults, continuous disposal zones can be found and used with minimal pressure build-up.

\subsubsection{Overlying Sediments}

The sediments overlying the caprock have been included in the Lissie formation which can be divided, for convenience, into an upper Montgomery sand and a lower sand which may be correlated with the Bentley. 
The Willis formation is found above the caprock, suggesting that all sediments over the dome are middle Pleistocene and younger.

\subsection{Caprock}

The simple structure of this dome is shown in the Pleistocene beds above the caprock, mapped at the lower sand level in the Lissie. The dome is almost circular and unfaulted.

All of the Freeport sulfur well data has been included in the remapping and interpretation of caprock (Figure 2). The caprock edge merges into the top of the Miocene, the last fully-marine sediments. Since offshore domes have little or no caprock, it thus appears that the caprock at Bryan Mound is Pliocene and younger in age.

\subsubsection{Anomalous Zones}

The anomalous zones (AZs) that often occur between major segments in salt stocks, called lobes or spines by various authors [Neal et al., 1993], show as linear depressions, actually grabens, on the caprock upper surface. They are bounded by normal faults which meet at the top of salt. The principal northwest-southeast $A Z$ is apparent on the caprock contours and is congruent with the gravity flexure and external structural features at depth (Figures 5 and 7). At least one more $\mathrm{AZ}$ almost normal to it appears to be present, segmenting the salt stock into at least four discrete lobes. The northnortheast / south-southwest trending $\mathrm{AZ}$ is evidenced by more subtle surface topographic expression, by external structure manifested at depth, and by internal structural features in the salt, as observed on well logs. In salt stocks this large, four or more spines (lobes) are usually present; thus Bryan Mound appears typical. The limited expression of the AZs indicates strong water flow through the caprock, typical of the Brazos deltaic sands which the dome is buried in.

\section{$2.3 \quad$ Salt}

\subsubsection{Salt Nature and Internal Structure}

The dome salt at Bryan Mound contains significantly more shale (and possibly less anhydritic) than at domes further east. This agrees with the known changes in composition across the Coastal Salt Dome Basin, with more shale and sylvite near the western 
margin of the basin. Although present at Markham Dome just west of Bryan Mound, sylvite is not a significant constituent of this dome, even though it is present in trace amounts in many wells. However, black shale is a common impurity and may be responsible for some of the irregular cavern shapes that developed in the former Dow caverns (1-5), which were leached more than 40 years ago for brine production with less control than is now employed, using modern leach technology.

The anhydrite is less abundant than at Big Hill, as indicated by available logs. Most of the anhydrite bands seen on well logs are near vertical and parallel to the edge of the salt stock. Some of these anhydrite bands can be correlated between adjacent wells in a single cavern, but the more extensive mapping and correlation that enabled spine delineation at Big Hill [Magorian et al., 1988] was more difficult at Bryan Mound. A unique opportunity was present to determine internal structure using well log correlations in the six 3-well caverns that were drilled prior to the recognition that such leach configurations could create salt fall problems. Sections of shale or anhydrite layers which can be correlated on all three logs in Caverns 106 through 110 provide exact dip and strike of the internal structure and salt flow regime, allowing the identification of salt spines as accurately as in a mine (Figures 3a, b) The southwest-northeast section (Fig 3a) shows two sylvite bands found only in the southwest corner of the dome dipping outward from the southern spine. Dips on both flanks are seen. The anomalous zone (AZ) described by Thoms [in Neal et al., 1993] is crossed between Caverns 105 and 110 .

Shale dips to the southwest suggest that this AZ may itself dip southwest. This is the first time that any data on the possible dip of an $\mathrm{AZ}$ has been traced on logs. Both flank dips of the northeastern spine are seen.

The southeast-northwest section (Fig. 3b) shows the inner flank of the southern spine and crosses both AZs near their intersection. Only the inner flank of the northeastern spine was logged. The absence of outer spinal dips in this section is another indication of the width of available salt outside the present cavern array.

Neither section or any of the available logs show the western and northernmost spines. In almost all of the other caverns, two wells were drilled, as at Big Hill, showing the general direction of dip of correlative shale and anhydrite layers. The logs are not of sufficient sensitivity in most cases to allow satisfactory correlations, as fairly specific character is required to validate the correlations. 


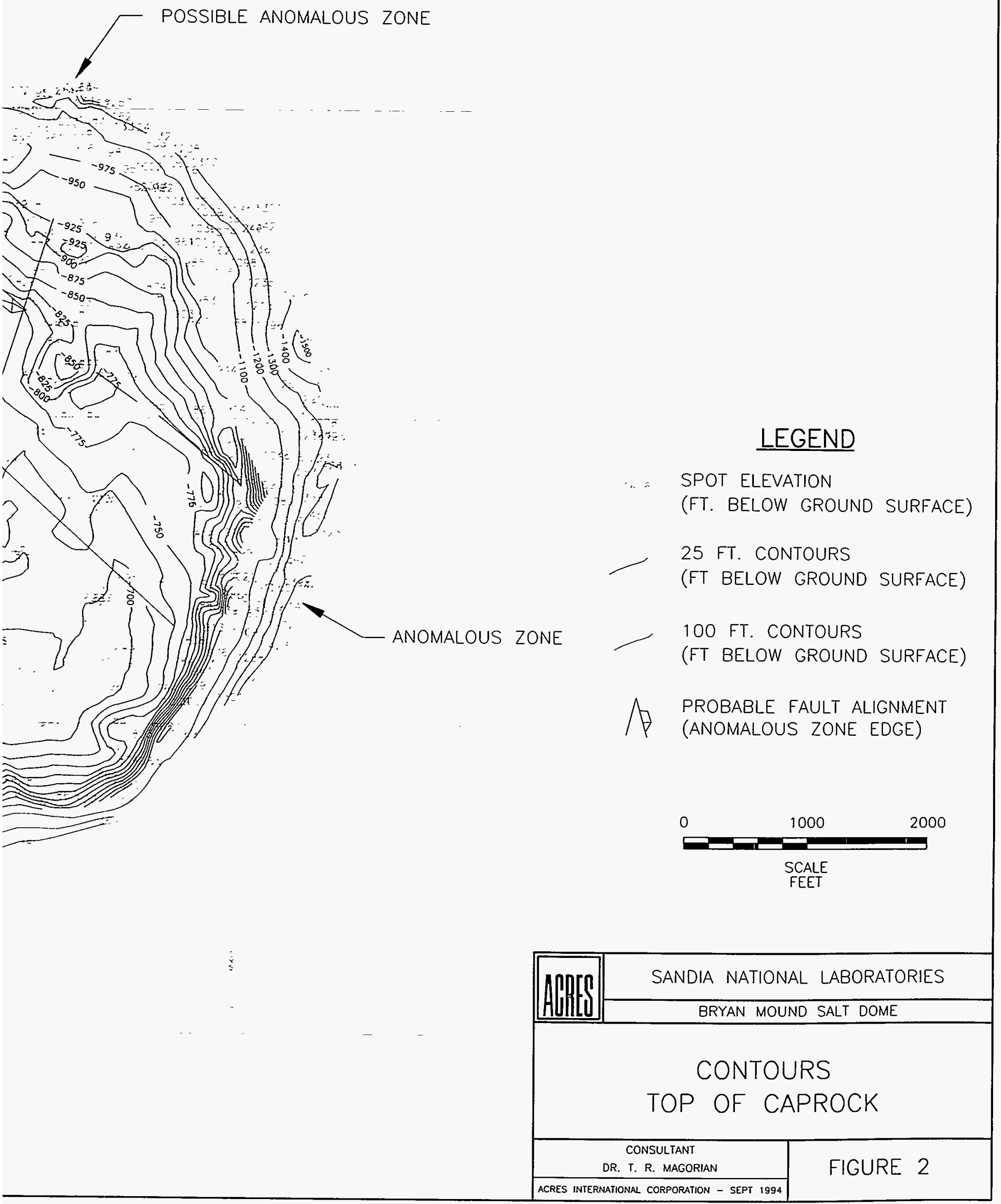


The character of salt as shown in thin sections includes clear salt with minor anhydrite, the most common secondary component. Black shale is the most common inclusion material. Some of it is slightly radioactive. Some of the less radioactive inclusions were sectioned. They all show highlyorganic black shale. This is normal, since in eutrophic sediments, the radioactivity is confined to the inorganic detritus. APPENDIX D contains photos of cores and thin sections.

\subsubsection{Shape of Salt Stock and Overhang Geometry}

Bryan Mound is more cylindrical than many domes (Figure 4, 4a). This may be due to four almost-equant spines, discussed below under "Salt Stock External Structure," which could have resulted in more uniform diapiric rise in individual segments, and in subsequent erosion. The top of the salt surface is more nearly level than found at most domes; this presumably results from water migration and associated caprock formation processes. The normal vertical shape of the Bryan Mound salt stock is modified in several significant ways. It leans to the southeast at depth, with a bulge on the northeast, an overhang on the south, and possibly other overhangs. In the zone of interest for cavern development from 2000 to 5000 feet, the salt edges are almost vertical like most domes, except near the minor bulge on the east. The overhangs are not believed to create a significant problem for storage, but must be mapped for any future expansion.

The most important difference in this interpretation as compared with the 1980 report [Hogan et al., 1980] is the overall dip of the axis of the dome, and the direction in which it leans. The 1980 interpretation relied on the 1949 refraction survey that indicated major overhangs on the west side, leading the authors to conclude that the salt stock leaned to the west. Additional access to this data along with analysis of the deep well control suggests that the salt stock leans slightly to the southeast, toward the coast. The bulge on the east side of the dome, which extended halfway around the dome in the 1980 characterization [Hogan et al.], is now believed to be more localized to the area of a few particular wells and adjacent fault block.

This revised interpretation is in agreement with Big Hill and some other domes that lean as much as $30^{\circ}$ toward the coast. The Five Island domes, particularly Avery Island and Cote Blanche, however, lean into the Iberia trough. A deep Frio trough east of Stratton Ridge may extend offshore southeast of this dome as well. 
DI

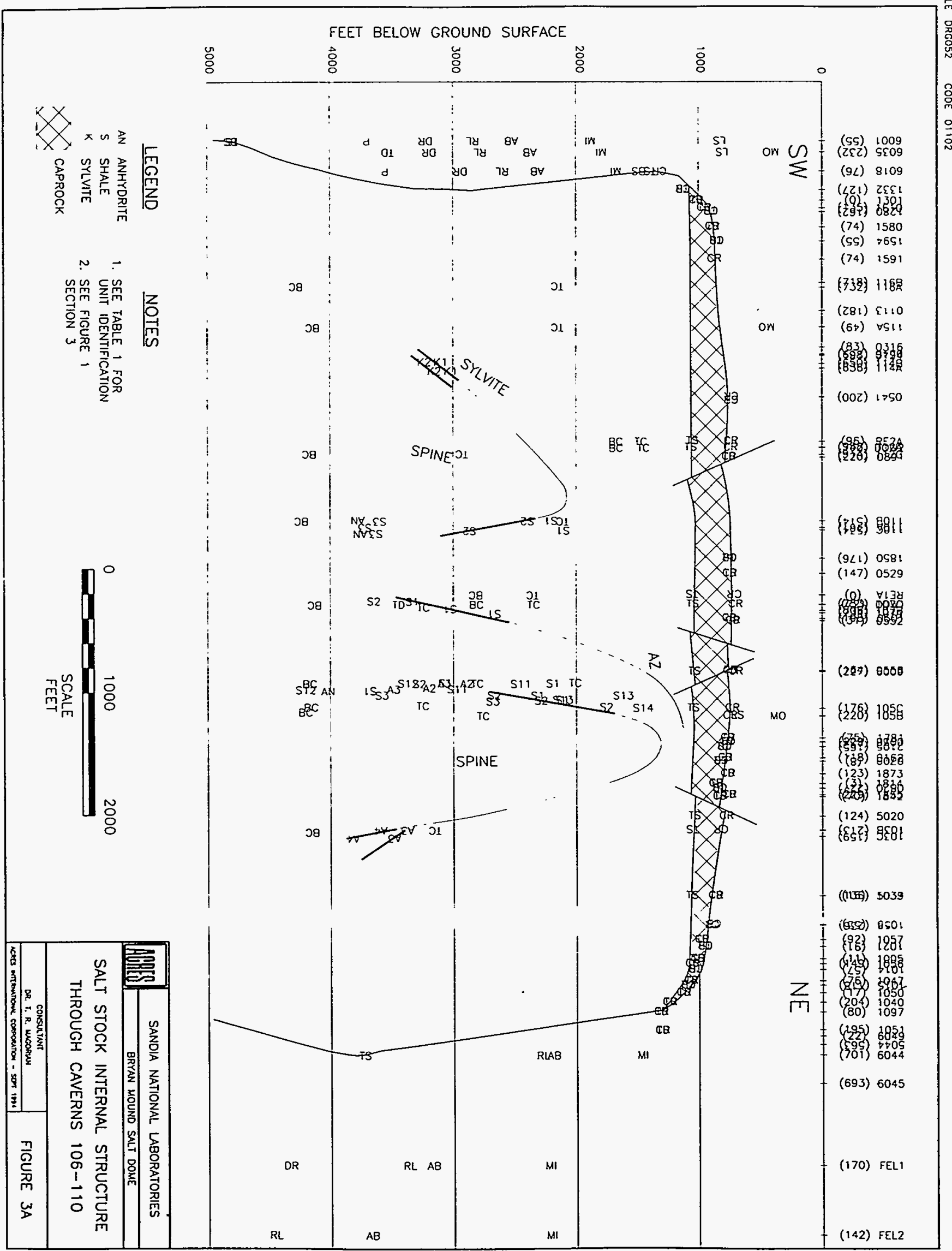


SI

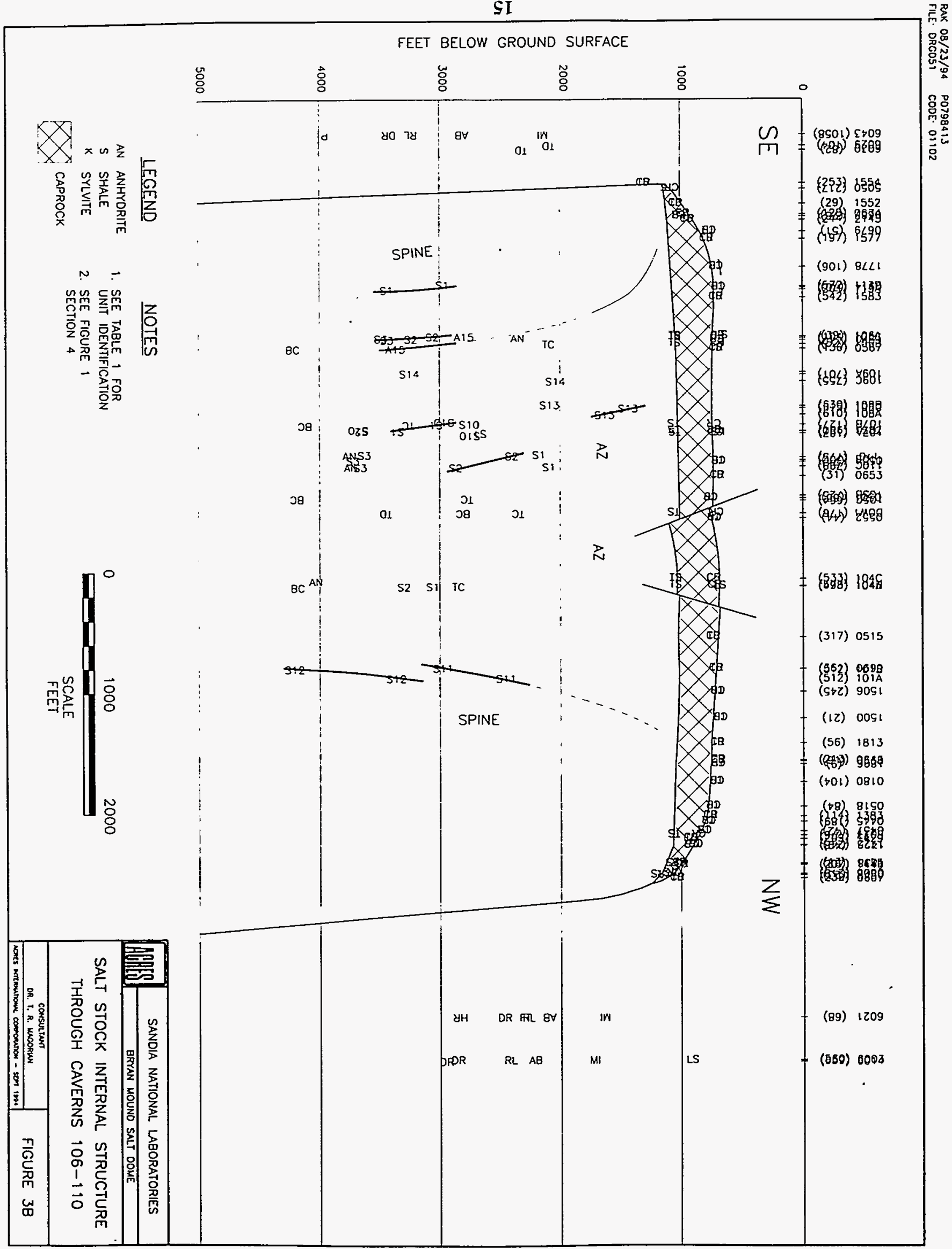




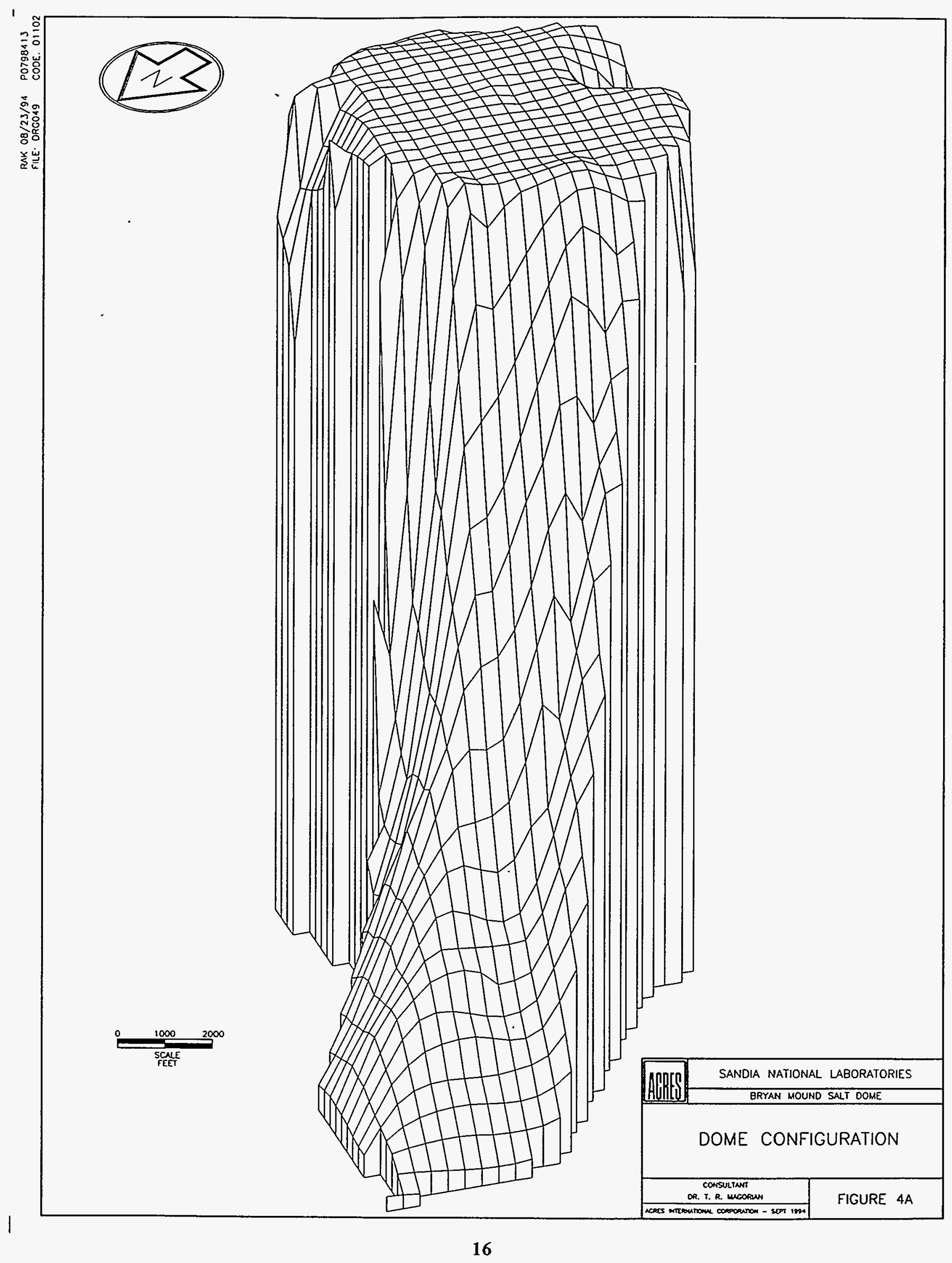




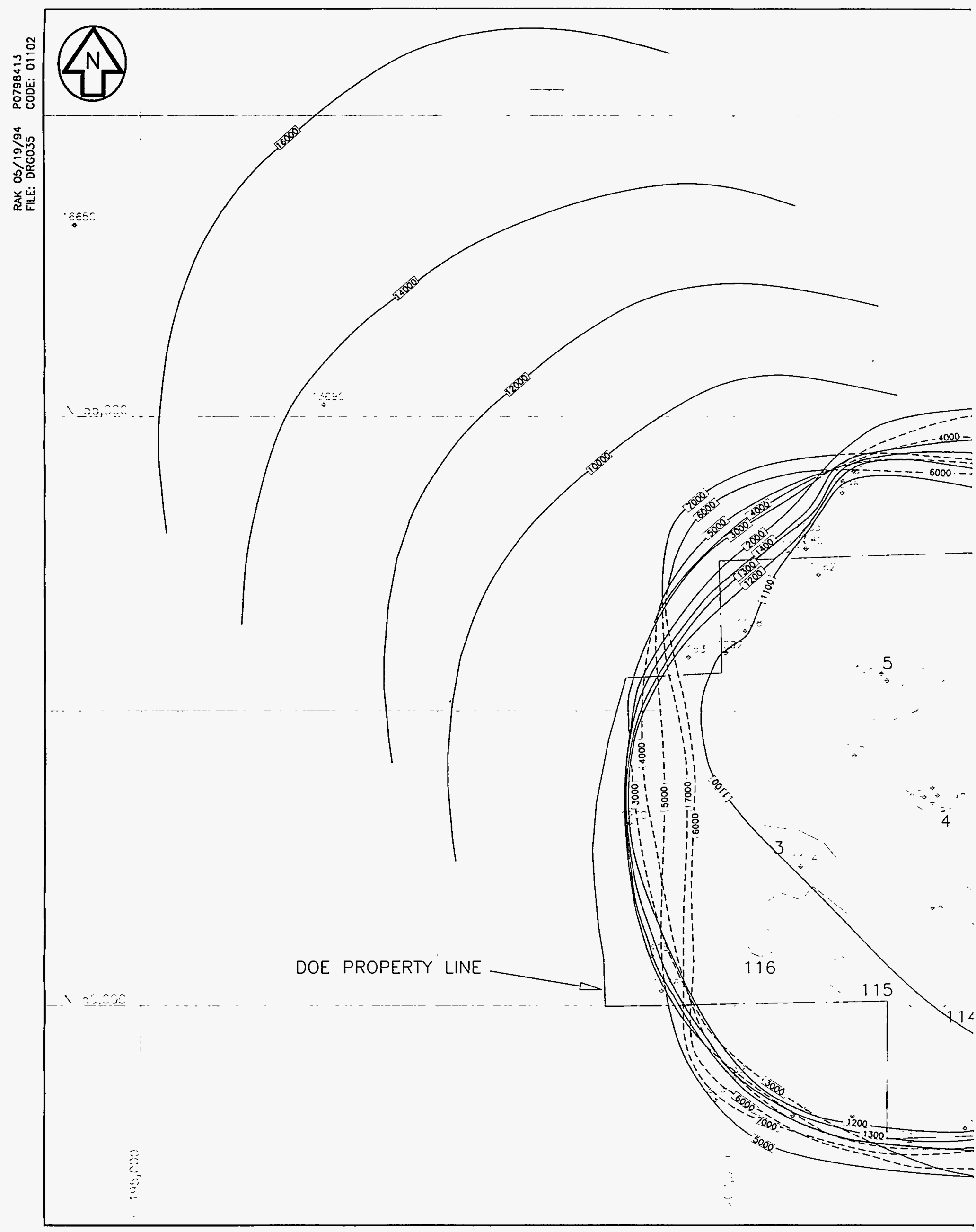


In the previous characterization report, the deep well data to the northwest was assumed to be part of an enormous conical salt mass. Such huge salt bodies, while generally accepted at the time, were never supported by gravity or other geophysical information and have now been shown to be impossible because the weak 40 milligal gravity anomaly makes a salt cone unlikely, thus also indicating the southeast-leaning salt stock. In fact, we know that salt domes grow not just from salt ridges, but from relatively shallow salt sills, with thick sediments beneath them.

Several shallow overhangs were mapped in the 1980 characterization, as interpreted from the 20 radial refraction profiles. The data at the edge of the salt stock is good only to 250 feet, and down to little more than half the depth of the central well. Since the central well was only 6173 feet deep, overhangs down to $\sim 3000$ feet may be imaged. The largest of these is the northwest overhang parallel to the outer flat on the caprock, which may cut out almost 1000 feet of salt on the northwest corner of the dome; however, this estimate has considerable uncertainty. While it may be the result of the arcuate fault on the south side (described below), it is difficult to fit the sediment dips and convergences found on the NW-SE cross-section (Figure 11) .
To most accurately resolve this uncertainty (if additional storage space were needed on this flank, for example), a modern Vertical Seismic Profile (VSP) or "Salt Proximity " survey would be required, hanging hydrophones in Cavern 5.

On the south side, an arcuate listric normal fault, concave against the dome, traps the oil found in the single productive well. Detailed drilling in and around this well shows clearly that the overhang formed by the fault does not extend more than a few hundred feet under the minor salt bulge. The south side overhang has been extended westward and back over 500 feet under the salt based on the same evidence, eliminating a possible cavern location. This could be resolved by another VSP, using hydrophones located in Cavern 115. The mechanism of this arc failure of steep sediments is indicated on the N-S cross section (Figure 9), where the fault is shown.

It appears that these overhangs may have been exaggerated in some earlier interpretations in order to develop oil prospects. However, it is also evident their lack of accurate mapping presents significant limitations in developing the full storage potential of this logistically well- situated dome, i. e., its location relative to transshipment connections. 


\subsubsection{Salt Stock External Structure}

In almost all circular domes, radial faults are created as the rising salt mass punctures through the overlying sediments and drags surrounding sediments upwards until they tear apart. Thus, close to the salt edge or wall, the steep sediments are tangentially or radially faulted. Some of the most important of such faults are the arcuate or curved tangentials discussed above; however, additional radial faults are known at the southeast corner of the salt stock and may be present elsewhere. The limited well control around the dome results from the very minimal hydrocarbon production and exploration, which makes it difficult to locate all such radial faults, and thus the detailed geometry of the salt edge.

The salt stock leans slightly to the southeast. This has been proven down to $16,630 \mathrm{ft}$ in the two deep wells on the northwest flank that penetrate salt under the thick geopressured shale. The bulge on the east side at 5000 feet might suggest that the dome is a huge cone of salt. However, the gravity anomaly northwest of the oil storage, only some 40 milligals at Bryan Mound, makes the salt cone highly improbable and thus indicating that the entire salt stock is leaning to the southeast (Figure 5).
Reflection seismic data that is obtained for oil and gas exploration, in which the salt stock flank is not imaged, is often adequate to define the flanks of a piercement dome, provided the sediment reflections are properly migrated, and the caprock does not overhang the salt edge. Unfortunately, at Bryan Mound, the highly-sulfurous caprock overhangs in exactly this way, down to the top of the Miocene.

At the top of the Miocene (Figure 6), the well control shows an essentially circular salt stock, with a down-to-the-coast radial fault on the northwest corner, a horst block (a pair of radial faults converging upward) on the northeast corner, and an apparent tangential growth fault on the south side trapping oil against the salt in the single productive well.

A large regional fault on the northwest side creates a flat spot on the salt stock which is otherwise almost perfectly circular. Its continuation around the north side is almost unknown because only two shallow wells penetrate sediments within the area of domal convergence. This may be part of a large arcuate listric normal fault, down-tothe-coast, which is tied to the side of the dome and extends to the northeast. The faulted feature drilled by the Feldman and 


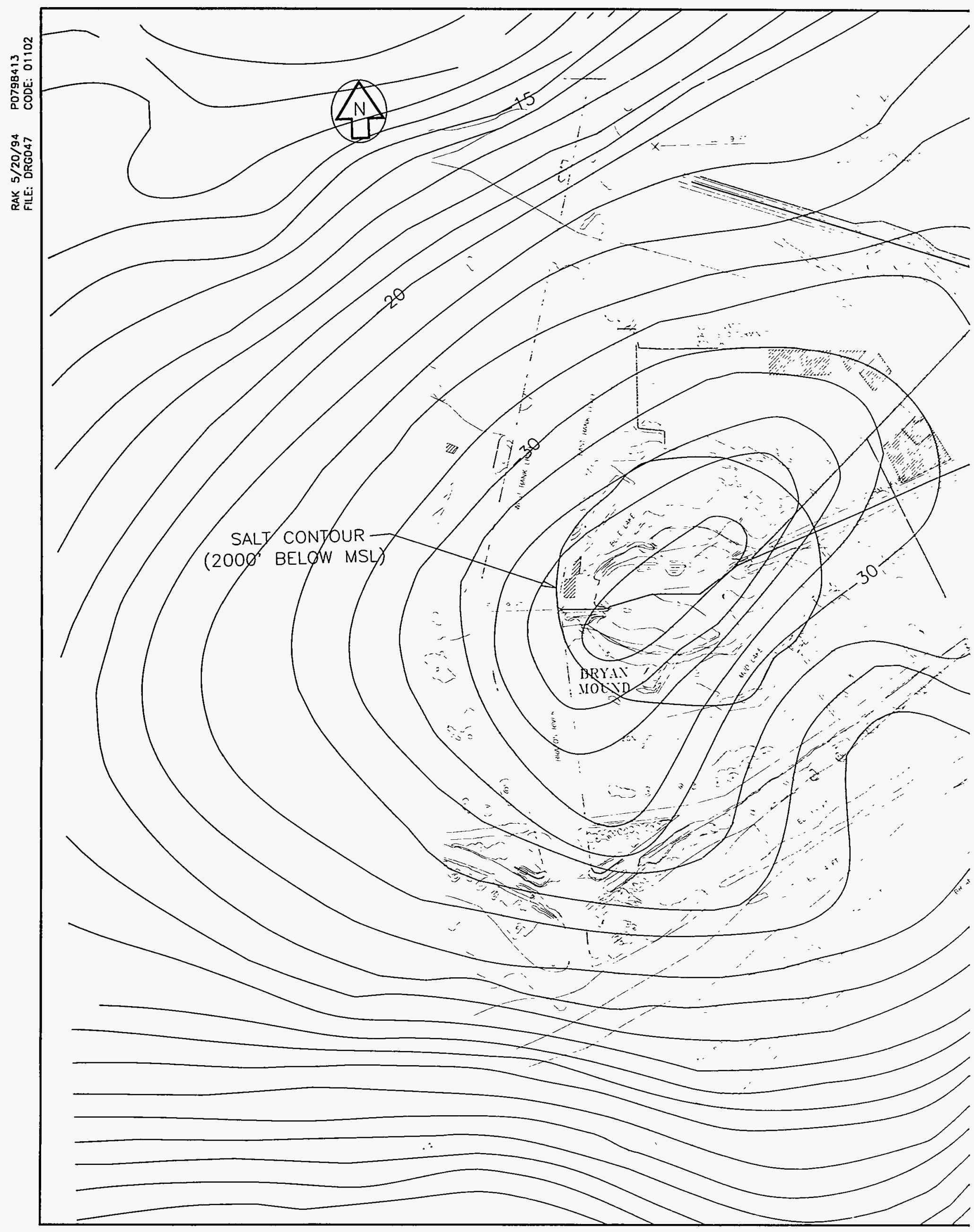

- TE 


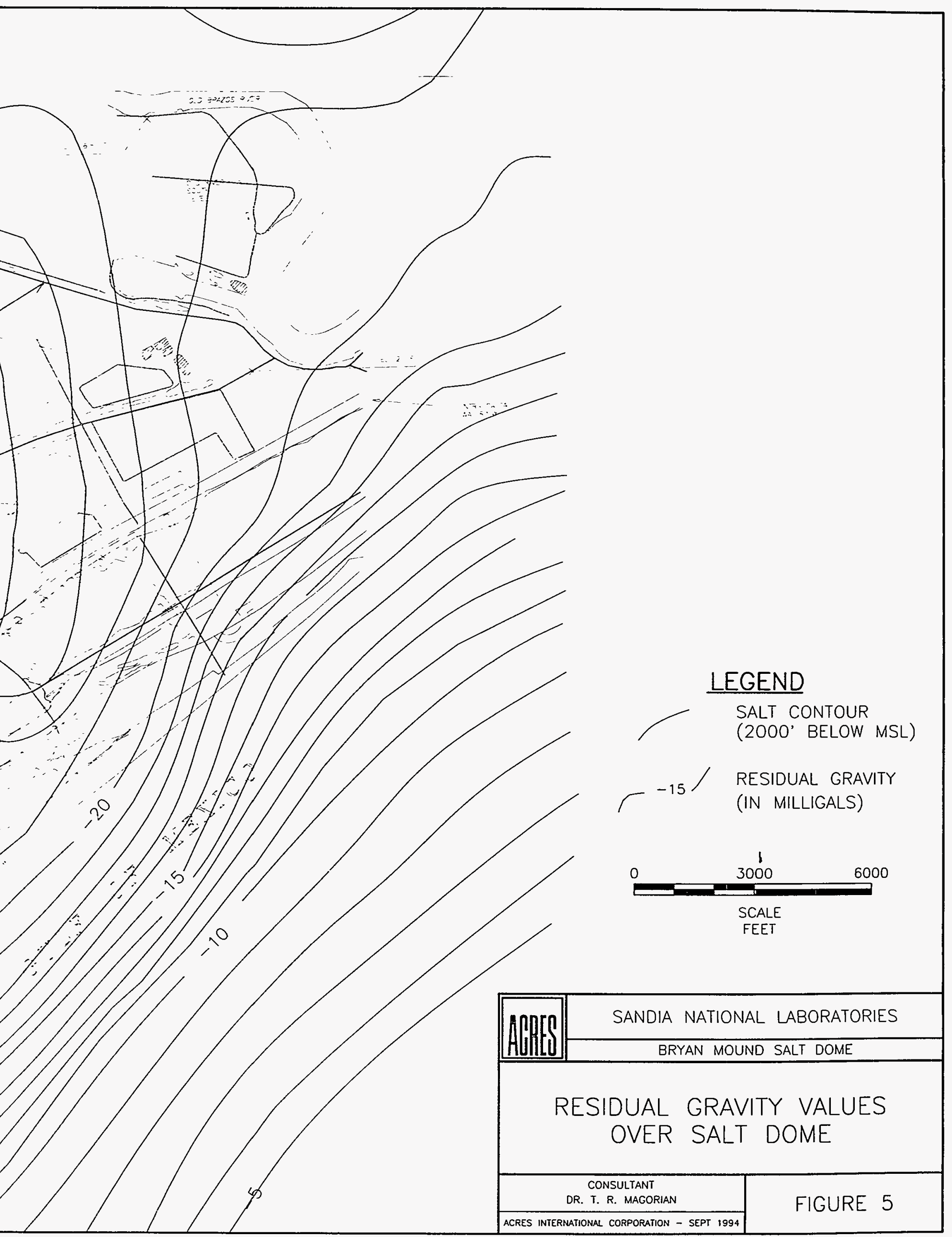




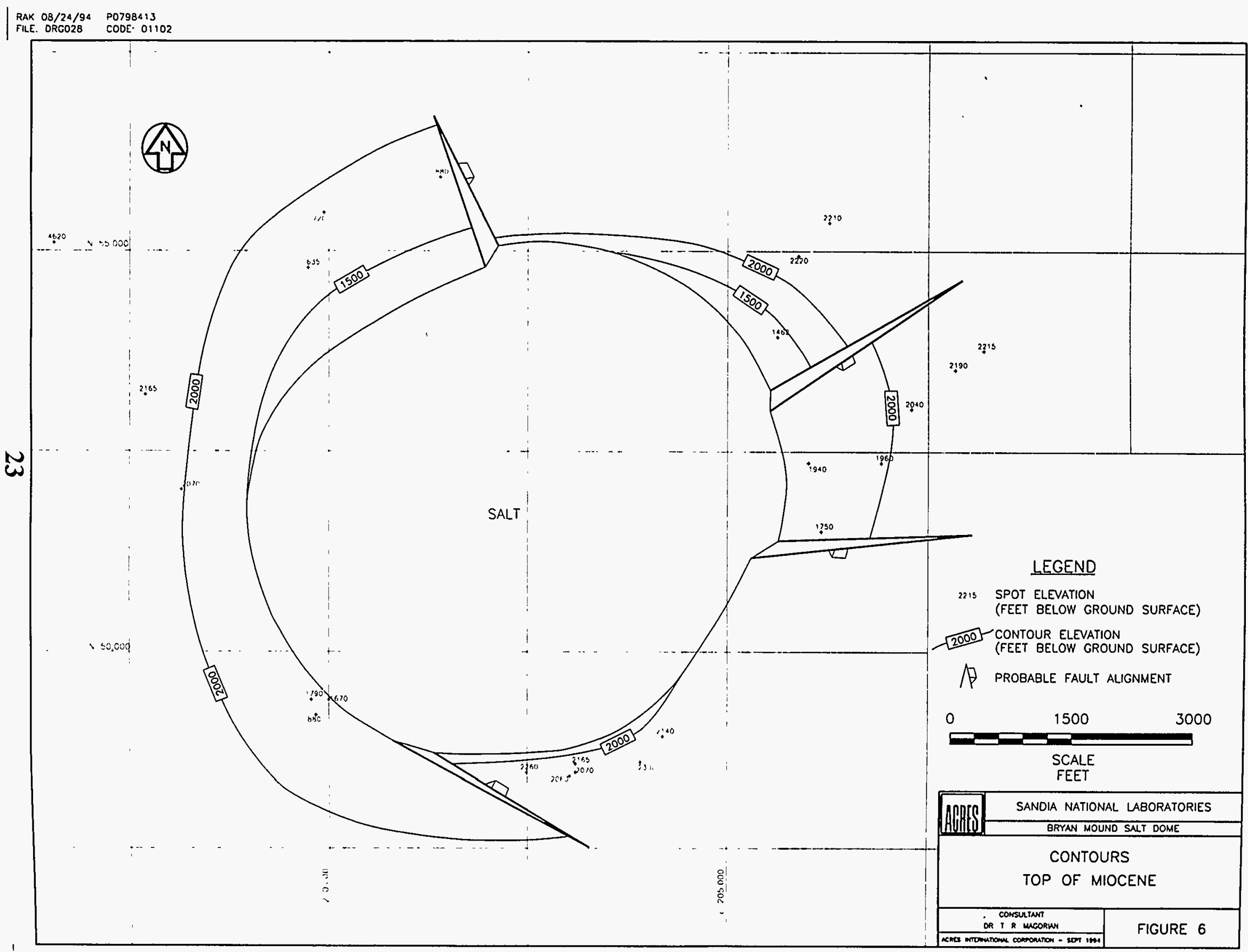


other wells, and beyond appears to be a radial horst block bounded by a radial fault extending northeast from the salt stock. A tangential fault apparently bounds the overhang on the south side, creating the trap for the limited oil production.

\subsubsection{Shale Sheath and Convergence of Sediments on Dome Flanks}

The Anahuac shale forms a mobile sheath around most of the salt stock below $3000 \mathrm{ft}$ (Figure 7). At geopressure, this light volcanic-ash-rich mud has floated up with the salt to form an impenetrable hydrological barrier if a cavern were to be leached inadvertently to the edge of the salt. This is especially noticeable on the east side of the dome. The possibility of large inclusions in the salt along the deep flanks is remote, although highest near the major fault zones, since these and the anomalous zones are as- sociated with important inclusions found in mines. Although the flat top of the dome is irregular in detail with karst solution features, the steep flanks are remarkably free of detailed irregularities, commensurate with the faulted nature of their intrusive origin.

Convergence of sediments on the flanks can be used both to locate the edge of the salt stock in the absence of penetrating wells, and to calculate the rate of stock growth. Little convergence is apparent in the geopressured Anahuac but increases through the deltaic Miocene sand pile, reaching its maximum on the northwest side under the Pliocene unconformity. Limited convergence is found in areas of overhang. None of the overhangs above 10,000 feet show any evidence of being more than a few hundred feet deep horizontally into the salt, including the oil-bearing south side which has been drilled with several side-tracked holes.

\subsection{Structural Interpretation}

The interpretations described in the preceding paragraphs are significant in understanding safety margins for existing caverns and for establishing possible locations for additional caverns. The structural interpretations can best be understood by viewing the cross-sections presented in Figures 8-12. 
$\begin{array}{ll}\text { RAK } 08 / 24 / 94 & \text { PO798413 } \\ \text { FILE. DRCO29 } & \text { CODE } 01102\end{array}$

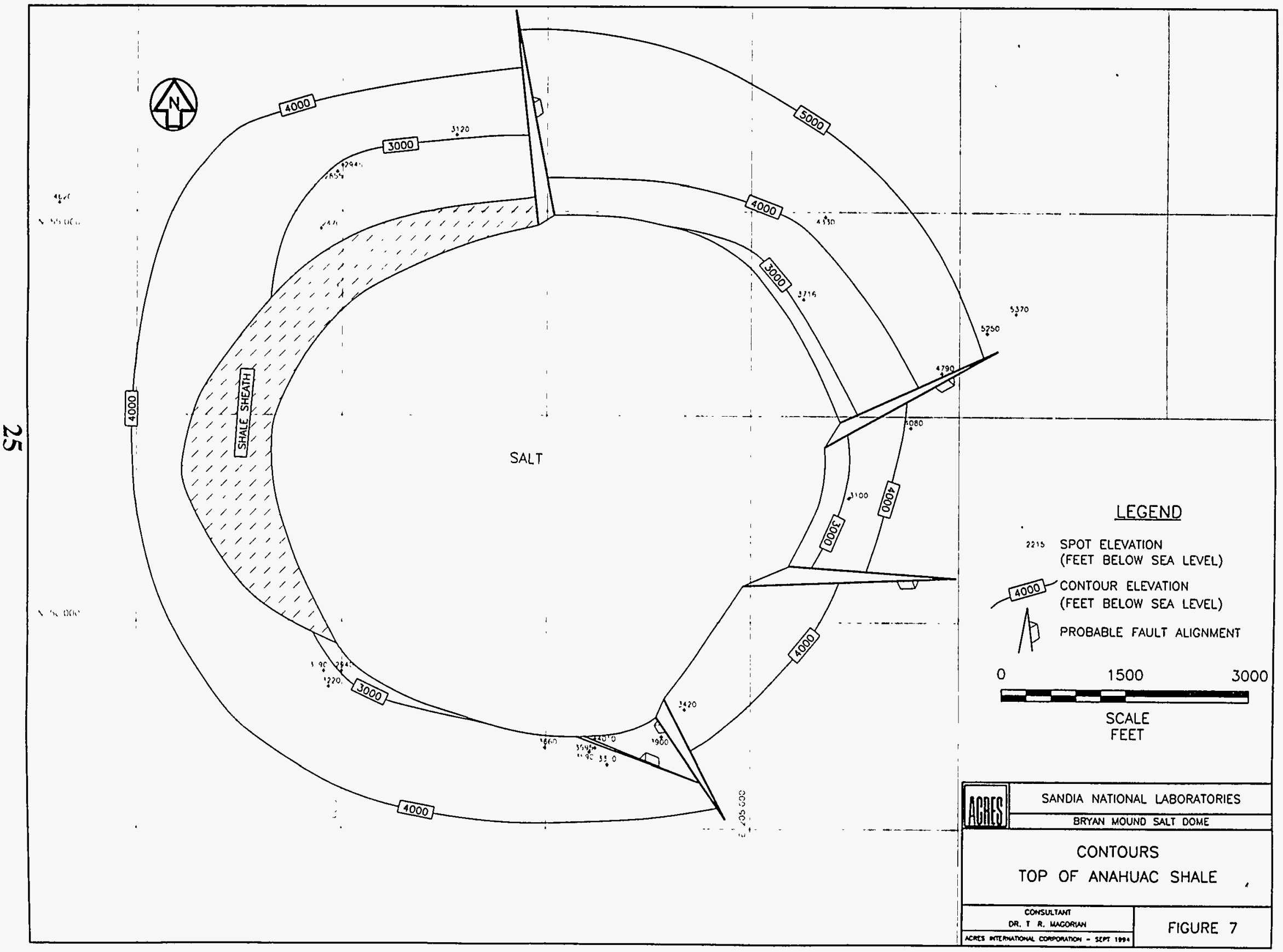




\subsubsection{Geologic Cross-Sections}

The major changes that affect the subsurface geologic profiles shown in the previous 1980 characterization involve the overall dip of the deep salt stock and the location and depth of the shale sheath and shallow overhangs. Most of these differences involve the extrapolated interpretation of the 1949 refraction seismic survey since there is little change in the amount or interpretation of subsurface data.

\section{East-West: (Figure 8)}

The bulge on the east side of the dome is no longer believed to persist with depth. A significant change is discovery of a wide shale sheath below the middle Miocene (Alpine) UNCONFORMITY. The shape of the salt edge inside this geopressured sheath is unknown on this flank and may limit expansion of cavern storage until additional data is obtained. The summary of these flanks (Table 5 and Figure 16) indicate what is needed for possible expansion.

\section{North-South: (Figure 9)}

The overhang on the south side is essentially the same as mapped previously, although not included in any of the sections in the previous characterization. The north flank is still unknown.

\section{Southwest-Northeast: (Figure 10)}

This section shows little change from the previous characterization. The deep orientation of the salt stock is still unknown, although an overhang should develop below 5000 feet.

Northwest-Southeast: (Figure 11)

The most important cross-section through the dome runs from the deep Exxon (Humble) and Tenneco (Houston Oil and Minerals) wells up the northwest flank of the salt stock. The lower Miocene sands are present in the Freeport $\mathrm{A} 3$ but are absent nearer the salt stock in the Texaco 8, along with oil shows, indicating a wide shale sheath, possibly bounded by a large fault. The southeast flank is unknown and only assumed to be parallel. Sediment convergence indicated no significant overhang above 5000 feet.

\subsubsection{Anomalous Zones}

The anomalous zones (AZs) show as linear depressions, actually grabens, on the caprock upper surface. They are bounded by normal faults which meet at the top of salt. The principal northwest-southeast $\mathrm{AZ}$ is apparent on the caprock contours and is congruent with the gravity flexure and external structural features at depth (Figures $\mathbf{5}$ and 


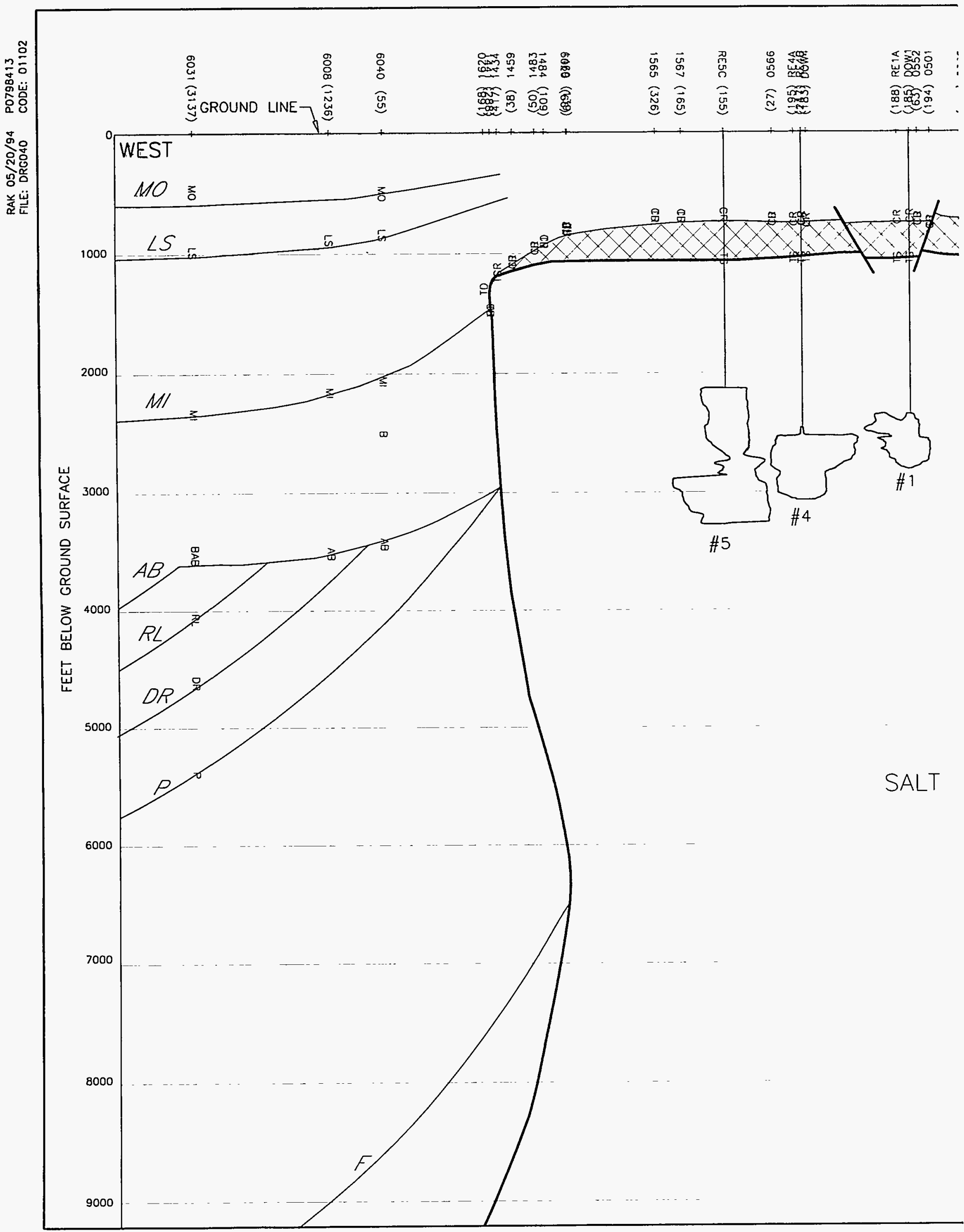




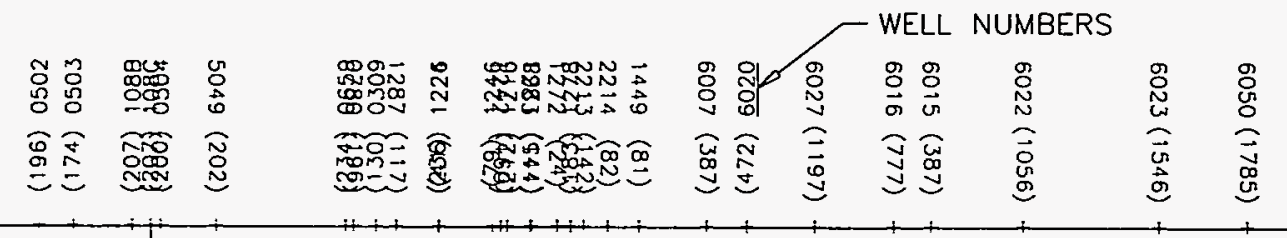

TEAST
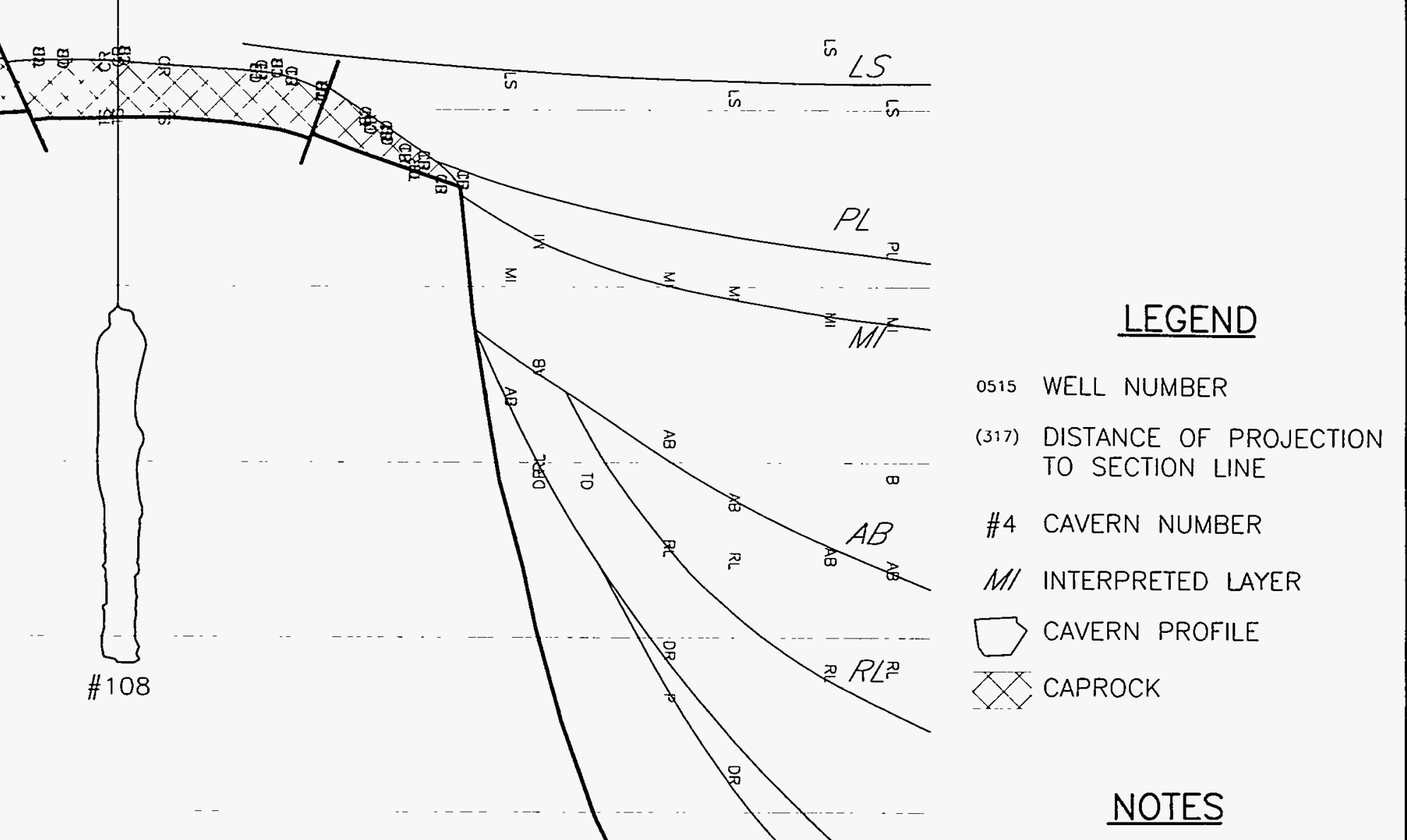


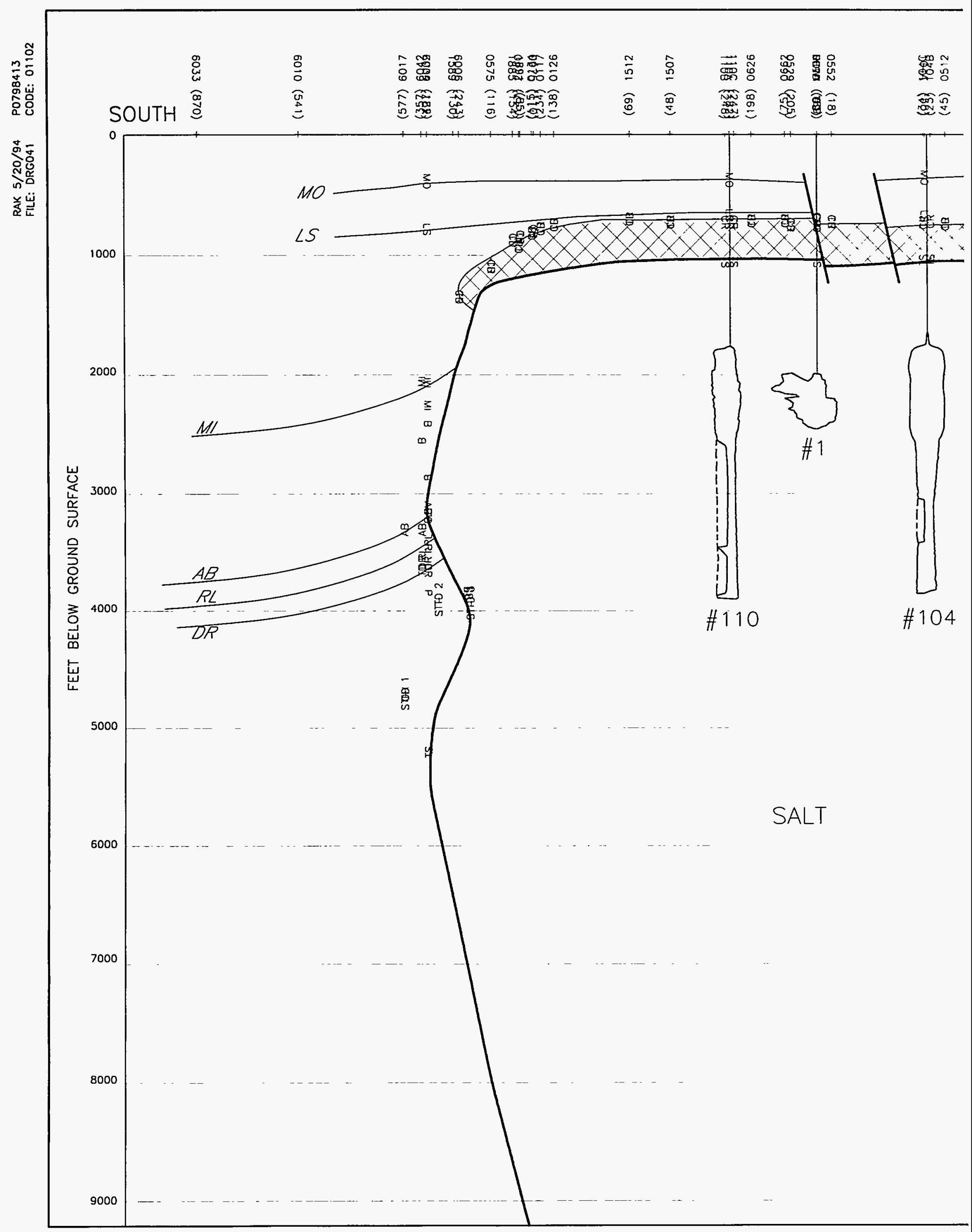




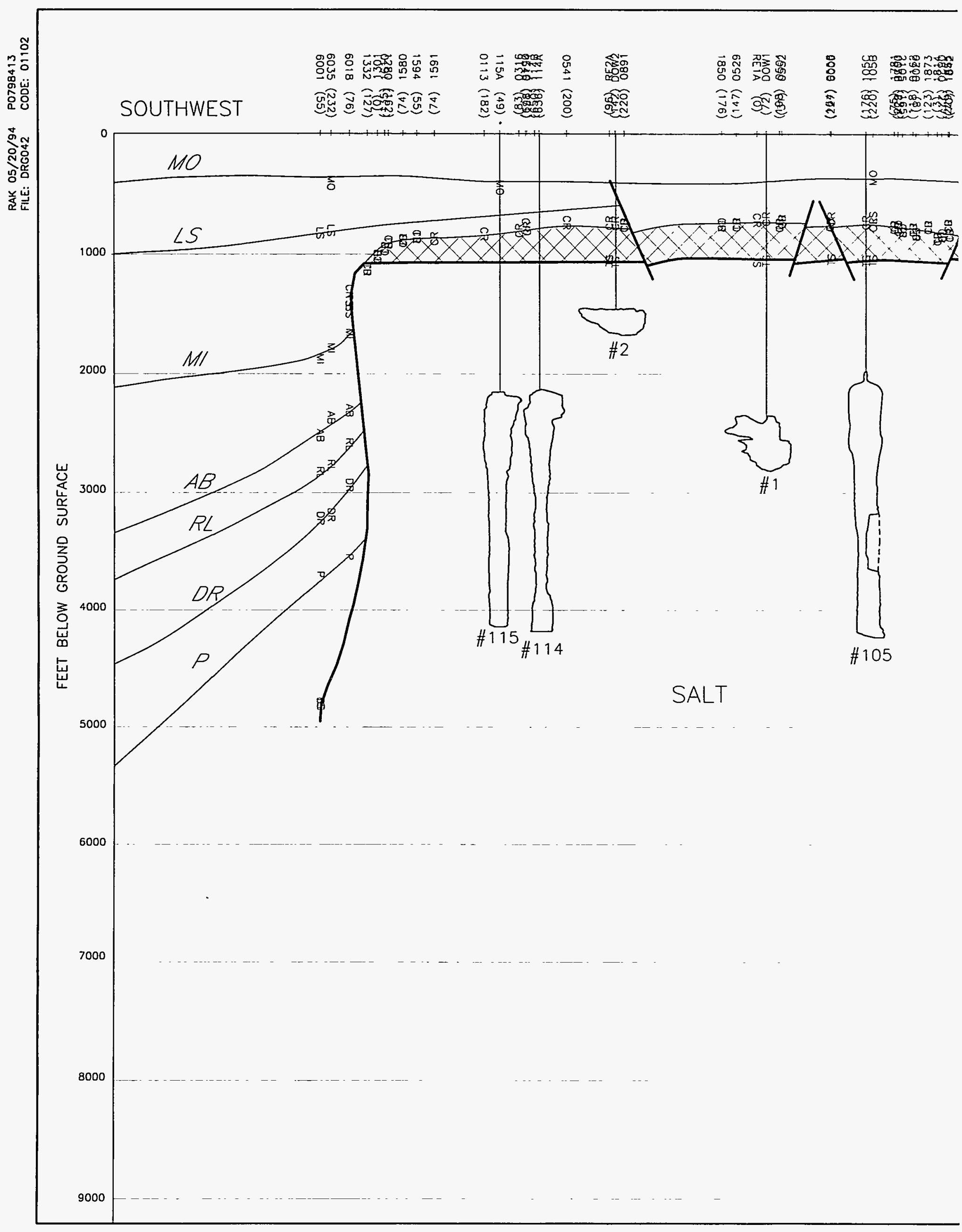




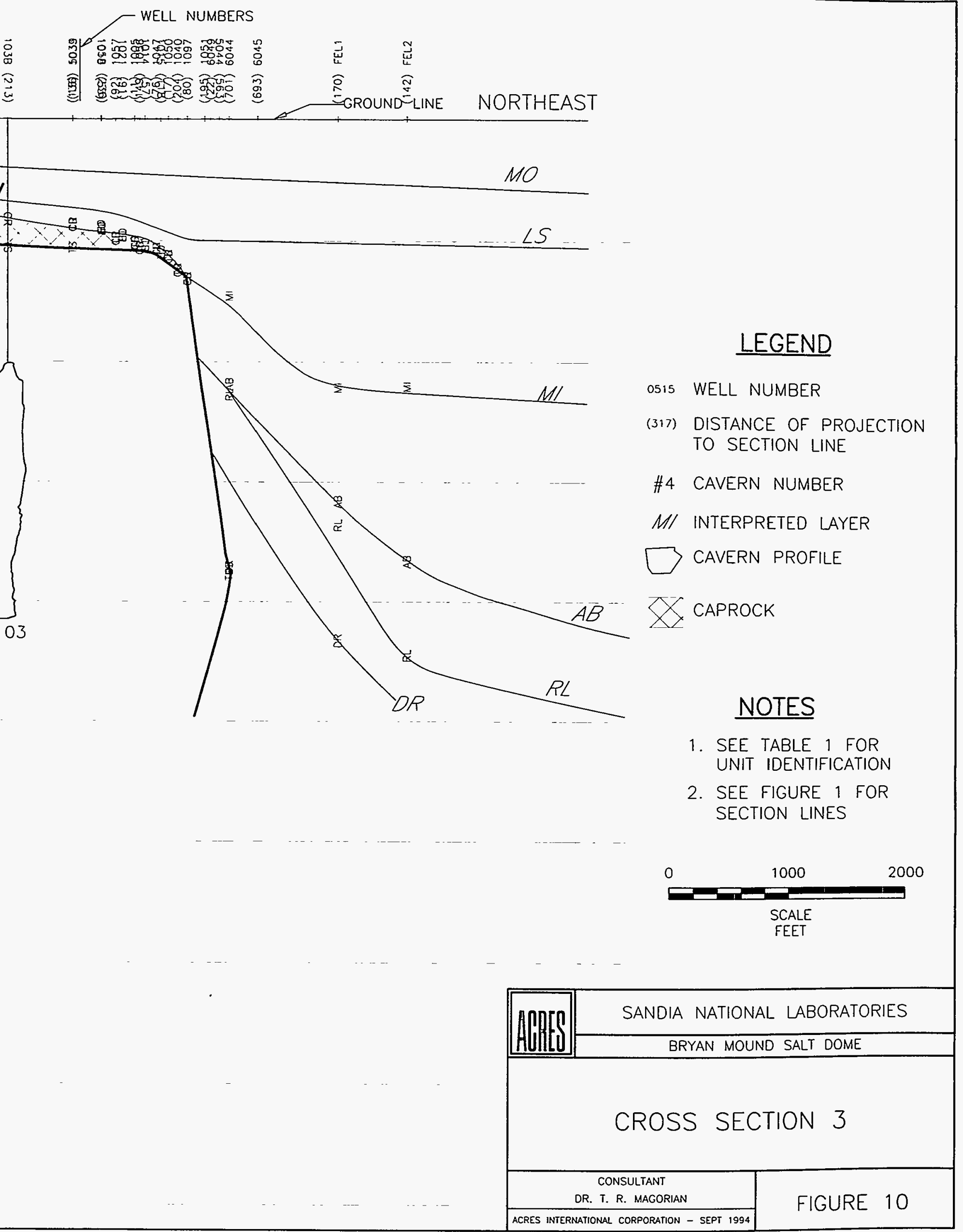




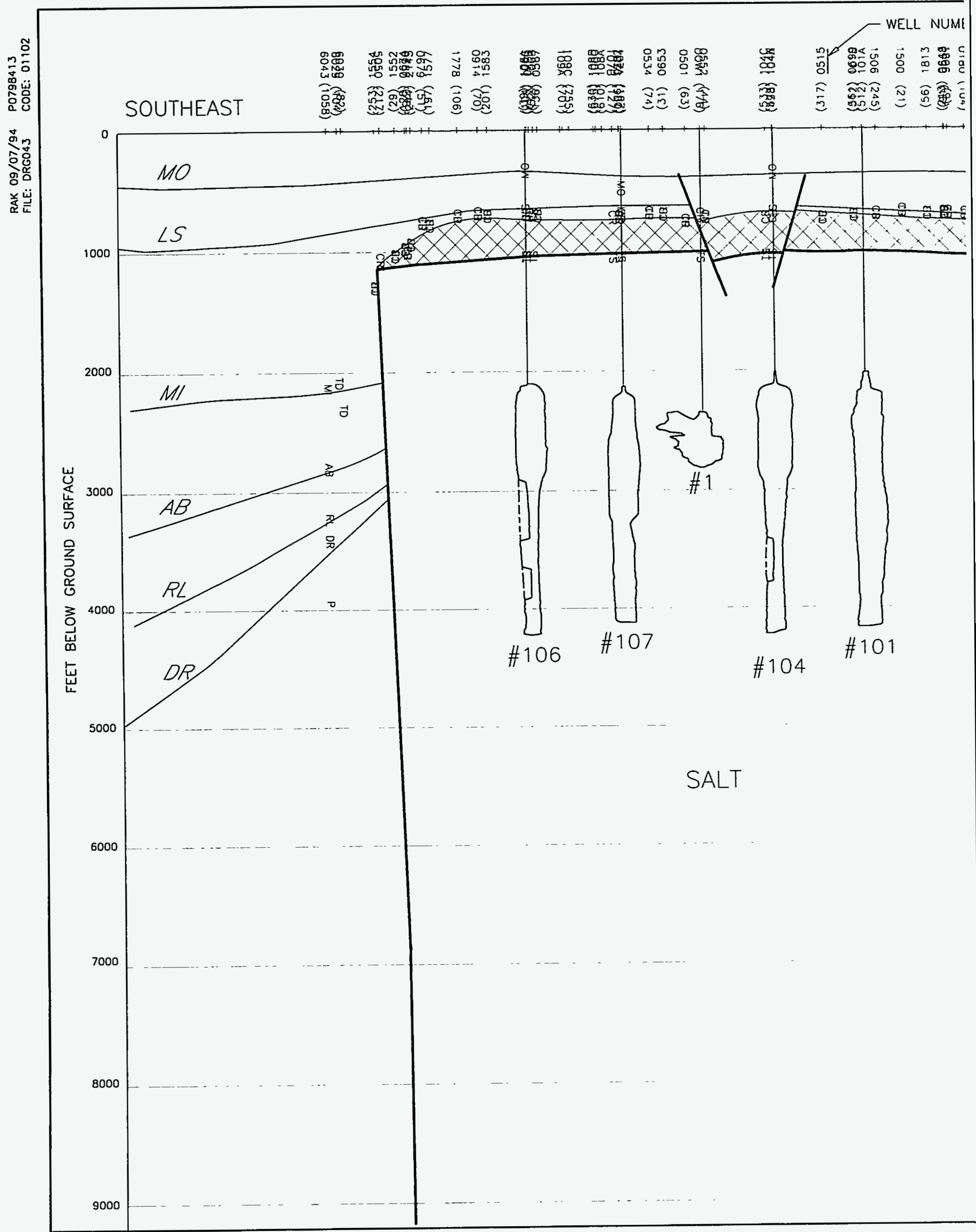


7). At least one more $A Z$ almost normal to it appears to be present, segmenting the salt stock into at least four discrete lobes. The north-northeast / south-southwest trending $\mathrm{AZ}$ is evidenced by more subtle surface topographic expression, by external structure manifested at depth, and by internal structural features in the salt, as observed on well logs. In salt stocks this large, four or more spines (lobes) are usually present; thus Bryan Mound appears typical. The limited expression of the AZs indicates strong water flow through the caprock, typical of the Brazos deltaic sands the dome is buried in.

\subsubsection{Correlation of Geologic Features with Gassy Caverns}

The occurrence of excessive dissolved gas in the oil at several SPR caverns has led to much speculation regarding both the origin and future trends. The association of the gas with known geologic features in the dome is speculative at this time, but some evidence suggests that the AZs may be conduits for higher gas permeability. More complete discussion of this association is contained in Section 2.4.2. and 3.1.2.

\section{SPR SYSTEM CONSIDERATIONS}

\subsection{Cavern Configurations}

Table 2 was compiled by DynMcDermott Petroleum Operations and lists the most relevant parameters associated with cavern integrity. All depths are given in feet below the bradenhead flange (which varies from about 4.4 to $16.5 \mathrm{ft}$ amsl), but caverninduced subsidence is very gradually lowering the surface. A brief description of the data follows:
"Cavern number" is shown on Figures 1 (base map), 13, and the Frontispiece.

"Year started" indicates initial startup of leaching, but does not include workovers, etc., performed subsequently for SPR modification.

"Cavern volume," in millions of barrels, is usually about $10 \%$ larger than the volume of stored material, allowing for brine in the cavern bottom. 
Table 2 Bryan Mound Cavern Geotechnical Parameters

\begin{tabular}{|c|c|c|c|c|c|c|c|c|c|c|c|c|c|c|c|c|c|c|c|c|}
\hline CAVERN & $\begin{array}{l}\text { SPR } \\
\text { BM } 1\end{array}$ & $\begin{array}{l}\mathrm{SPR} \\
\mathrm{BM} 2 \\
\end{array}$ & $\begin{array}{l}\text { SPR } \\
\text { BM } 4\end{array}$ & $\begin{array}{l}\text { SPR } \\
\text { BM } 5 \\
\end{array}$ & $\begin{array}{c}\text { SPR } \\
\text { BM } 101\end{array}$ & $\begin{array}{c}\text { SPR } \\
\text { BM } 102 \\
\end{array}$ & $\begin{array}{c}\text { SPR } \\
\text { BM } 103 \\
\end{array}$ & $\begin{array}{c}\text { SPR } \\
\text { BM } 104 \\
\end{array}$ & $\begin{array}{c}\text { SPR } \\
\text { BM } 105 \\
\end{array}$ & $\begin{array}{c}\text { SPR } \\
\text { BM } 106 \\
\end{array}$ & $\begin{array}{c}\text { SPR } \\
\text { BM } 107\end{array}$ & $\begin{array}{c}\text { SPR } \\
\text { BM } 108 \\
\end{array}$ & $\begin{array}{c}\text { SPR } \\
\text { BM } 109 \\
\end{array}$ & $\begin{array}{c}\text { SPR } \\
8 M 110 \\
\end{array}$ & $\begin{array}{c}\text { SPR } \\
\text { BM } 111 \\
\end{array}$ & $\begin{array}{c}\text { SPR } \\
\text { BM } 112 \\
\end{array}$ & $\begin{array}{c}\text { SPR } \\
\text { BM } 113 \\
\end{array}$ & $\begin{array}{c}\text { SPR } \\
\text { BM } 114 \\
\end{array}$ & $\begin{array}{c}\text { SPR } \\
\text { BM } 115 \\
\end{array}$ & $\begin{array}{c}\text { SPR } \\
\text { BM } 116 \\
\end{array}$ \\
\hline $\begin{array}{c}\text { YEAR } \\
\text { STARTED }\end{array}$ & 1942 & 1942 & 1942 & 1957 & 1982 & 1980 & 1982 & 1980 & 1980 & 1980 & 1980 & 1980 & 1980 & 1980 & 1983 & 1980 & 1984 & 1984 & 1984 & 1984 \\
\hline $\begin{array}{l}\text { NUMBER } \\
\text { OF WELLS }\end{array}$ & 2 & 2 & 3 & 3 & 2 & 2 & 2 & 3 & 2 & 3 & 3 & 3 & 3 & 3 & 2 & 2 & 2 & 2 & 2 & 2 \\
\hline $\begin{array}{c}\text { CAVERN } \\
\text { VOLUME, MMB } \\
\end{array}$ & 8.46 & 6.32 & 20.68 & 37.87 & 11.23 & 11.52 & 11.43 & 11.7 & 11.39 & 12.45 & 11.4 & $\begin{array}{r}12.17 \\
\end{array}$ & 11.57 & 11.42 & 11.21 & 10.98 & 7.07 & 8.23 & 10.32 & 10.74 \\
\hline $\begin{array}{c}\text { TOP } \\
\text { CAPROCK } \\
\end{array}$ & -730 & -766 & -760 & -720 & -734 & -824 & -852 & -755 & -776 & -729 & -756 & -760 & -725 & -765 & -938 & -747 & -845 & -860 & -865 & -890 \\
\hline $\begin{array}{l}\text { TOP } \\
\text { SALT }\end{array}$ & -1136 & -1070 & -1065 & -1090 & -1062 & -1067 & -1063 & -1058 & -1064 & -1065 & -1073 & -1073 & -1085 & -1075 & -1078 & -1064 & -1066 & -1074 & -1079 & -1086 \\
\hline $\begin{array}{l}\text { CASING } \\
\text { SEAT }\end{array}$ & -2166 & -1376 & -1496 & -1928 & -1995 & -1994 & -1990 & -1987 & -1971 & -1980 & -1992 & -1980 & -1970 & -1988 & -1961 & -1979 & -2004 & -2005 & -2011 & -2006 \\
\hline $\begin{array}{c}\text { TOP } \\
\text { CAVERN }\end{array}$ & -2349 & -1450 & -2095 & $-210 ?$ & -1998 & 2903 & -2122 & -2108 & -2050 & -2106 & -2150 & -2166 & -2132 & -2140 & -2130 & -2065 & -2134 & -2130 & -2146 & -2100 \\
\hline $\begin{array}{c}\text { BOTTOM } \\
\text { CAVERN (DATE) }\end{array}$ & $\begin{array}{l}-2349 \\
-2762 \\
(9 / 92) \\
\end{array}$ & $\begin{array}{l}-1450 \\
-1670 \\
(3 / 93) \\
\end{array}$ & $\begin{array}{l}-2495 \\
-3076 \\
(10 / 92) \\
\end{array}$ & $\begin{array}{l}-2102 \\
-3273 \\
(1 / 93) \\
\end{array}$ & $\begin{array}{l}-1998 \\
-4159 \\
(10 / 92) \\
\end{array}$ & $\begin{array}{l}-203 \\
-4237 \\
(3 / 93) \\
\end{array}$ & $\begin{array}{l}-2422 \\
-4133 \\
(4 / 91) \\
\end{array}$ & $\begin{array}{l}-2108 \\
-4163 \\
(2 / 93) \\
\end{array}$ & $\begin{array}{l}-2050 \\
-4193 \\
(12 / 92) \\
\end{array}$ & $\begin{array}{r}-4011 \\
-12 / 92) \\
\end{array}$ & $\begin{array}{l}-47097 \\
-411 / 92) \\
\end{array}$ & $\begin{array}{l}-2100 \\
-4130 \\
(6 / 93) \\
\end{array}$ & $\begin{array}{l}-4176 \\
(2 / 93) \\
\end{array}$ & $\begin{array}{l}-4122 \\
(3 / 93) \\
\end{array}$ & $\begin{array}{l}-4128 \\
(12 / 92) \\
\end{array}$ & $\begin{array}{l}-4105 \\
(2 / 93) \\
\end{array}$ & $\begin{array}{l}-4200 \\
(1 / 93) \\
\end{array}$ & $\begin{array}{l}-4166 \\
(1 / 93) \\
\end{array}$ & $\begin{array}{l}-4130 \\
(1 / 93) \\
\end{array}$ & $\begin{array}{r}-3945 \\
(10 / 92) \\
\end{array}$ \\
\hline $\begin{array}{l}\text { CAVERN } \\
\text { HEIGHT(H) }\end{array}$ & 413 & 220 & 581 & 1171 & 2161 & 2034 & 2021 & 2055 & 2143 & & & & & & & & & 2036 & 1994 & 1895 \\
\hline $\begin{array}{c}\text { HEIGHT (H) } \\
\text { DIAMETER (D) }\end{array}$ & $\begin{array}{l}413 \\
383\end{array}$ & $\frac{220}{453}$ & 504 & 481 & $\frac{2101}{193}$ & 201 & 201 & 202 & 195 & $\frac{1905}{216}$ & $\frac{1946}{205}$ & $\frac{1964}{211}$ & $\frac{2044}{201}$ & $\frac{1982}{203}$ & $\frac{1998}{200}$ & $\frac{2040}{196}$ & $\frac{2066}{156}$ & $\frac{050}{170}$ & $\frac{194}{193}$ & $\frac{1845}{204}$ \\
\hline $\mathrm{H} / \mathrm{D}$ & 1.08 & 0.49 & 1.15 & 2.43 & 11.20 & 10.12 & 10.05 & 10.17 & 10.99 & 8.82 & 9.50 & 9.31 & 10.17 & 9.76 & 9.99 & 10.41 & 13.24 & 11.98 & 10.28 & 9.044 \\
\hline $\begin{array}{l}\text { NEAREST } \\
\text { CAVERN }\end{array}$ & 4 & 3 & 1 & 4 & 104 & 103 & 111 & 101 & 108 & 107 & 1 & 105 & 110 & 1 & 103 & 110 & 109 & 115 & 114 & 115 \\
\hline $\begin{array}{c}\text { PILLAR } \\
\text { THICKNESS (P) } \\
\end{array}$ & 237 & 450 & 237 & 320 & 469 & 577 & 414 & 469 & 425 & 476 & 329 & 425 & 426 & 417 & 414 & 451 & 438 & 492 & 492 & 517 \\
\hline P/D & 0.62 & 0.99 & 0.47 & 0.67 & 2.43 & 2.87 & 2.06 & 2.32 & 2.18 & 2.20 & 1.60 & 2.01 & 2.12 & 2.05 & 2.07 & 2.30 & 2.81 & 2.89 & 2.55 & 2.53 \\
\hline $\begin{array}{c}\text { मOOF } \\
\text { THICKNESS (B) }\end{array}$ & 1213 & 380 & 1430 & 1012 & 936 & 1136 & 1049 & 1050 & 986 & 1041 & 1077 & 1093 & 1047 & 1065 & 1052 & 1001 & 1068 & 1056 & 1067 & 1014 \\
\hline $\mathrm{B} / \mathrm{D}$ & 3.17 & 0.84 & 2.84 & $\frac{0.10}{2.10}$ & 4.85 & 5.65 & 5.22 & 5.20 & 5.06 & 4.82 & 5.25 & 5.18 & 5.21 & 5.25 & 5.26 & 5.11 & 6.85 & 6.21 & 5.53 & 4.97 \\
\hline $\begin{array}{c}\text { DISTANCE } \\
\text { TO EDGE (E) }\end{array}$ & 2410 & 1870 & 2290 & 1470 & 1490 & 1110 & 1220 & 1990 & 2310 & 1050 & 1800 & 1670 & 1430 & 2080 & 590 & 1340 & 680 & 1100 & 980 & 580 \\
\hline E/D & 6.29 & 4.13 & 4.54 & 3.06 & 7.72 & 5.52 & 6.07 & 9.85 & 11.8 & 4.86 & 8.78 & 7.91 & 7.11 & 10.25 & 2.95 & 6.84 & 4.36 & 6.47 & 5.08 & 2.84 \\
\hline $\begin{array}{c}\text { DISTANCE TO } \\
\text { PROPERTY LINE }\end{array}$ & 1360 & 715 & 1580 & 680 & 490 & 210 & 180 & 970 & 580 & 230 & 820 & 220 & 820 & 1310 & 240 & 860 & 340 & 219 & 115 & 273 \\
\hline $\begin{array}{l}\text { BHF ELEVATION } \\
\text { JAN } 1993\end{array}$ & 13.1 & 16.6 & 12.8 & 7.6 & 4.4 & 5.1 & 6.6 & 10 & 13.8 & 159 & 161 & 15.7 & 16 & 15.9 & 16 & 16.5 & 0 & 0 & 8 & 9 \\
\hline
\end{tabular}

Data current to July, 1993, with 1994 estimates of distance to edge (E) 


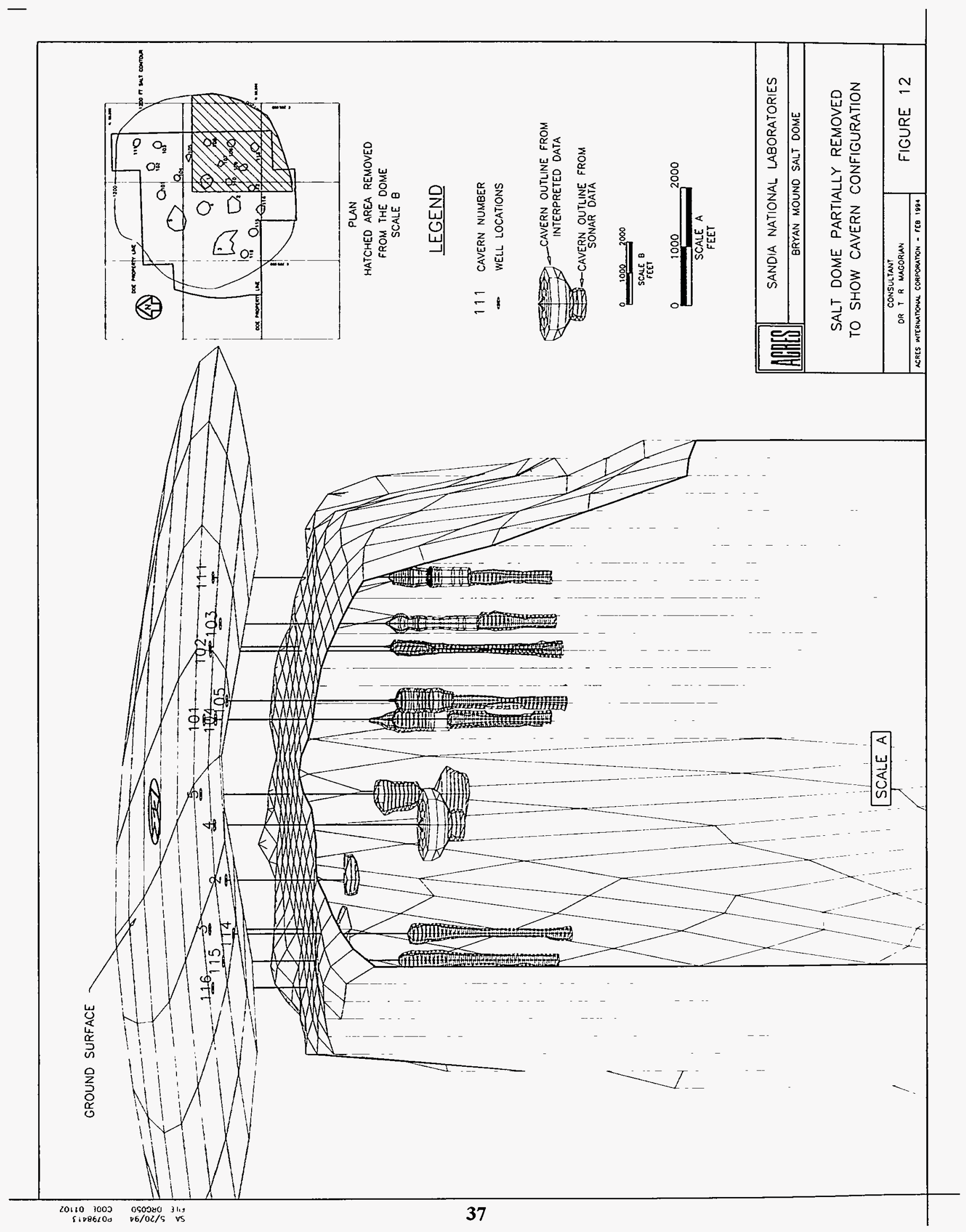


"Top of caprock and salt," respectively, are the uppermost surfaces of those units, with values averaged between the multiple wells.

"Casing seat," and "cavern top" (or bottom) is self-explanatory.

"Cavern Height $(\mathbf{H})$ " is the distance from cavern top to bottom.

"Diameter (D)" is the constructed diameter, which is an idealized (average) cylinder diameter that would correspond to the final cavern volume with the given height.

"H/D" is the ratio of the cavern height to the constructed diameter, providing a measure of the cavern shape.

"Pillar thickness $(\mathbf{P})$ " is the thickness of the pillar of salt between a cavern and its nearest neighbor.

"P/D" is the ratio of the pillar thickness and the constructed diameter, providing a relative measure of mechanical integrity.

"Roof thickness (B)" is the distance between the top of the cavern and the top of salt.

" $\mathrm{B} / \mathrm{D}$ " is the ratio of the roof thickness to the constructed diameter, providing a measure of mechanical integrity.

"Distance to dome edge $(\mathrm{E})$ " is the estimated distance between the cavern and the outside edge of dome salt.

"E/D" is the ratio of the distance to the edge of dome to the constructed diame- ter, providing a measure of mechanical integrity.

"Distance to property line" is the closest distance between the cavern edge and the SPR property line.

"BHF Elevation" is the bradenhead flange elevation in 1988 , rounded to $0.1 \mathrm{ft}$.

The values shown in Table 2 reflect the very conservative design approach used throughout the SPR system, especially for Caverns BM 101-116. The preexisting caverns (BM 1, 2, 3, 4, 5) do not follow those same guidelines, of course, but there have been few instability or safety issues associated with them. Cavern 3 was judged to be marginally unsuitable for oil storage, owing to its "pancake" shape, its generally shallow depth near the top of salt, and pressure integrity questions; thus it was plugged and abandoned. The shallow depth of Cavern 3 from $1520-1715 \mathrm{ft}$ leaves open the possibility for an additional cavern beneath, but offset laterally (see Section 3.5, "Expansion Cavern Possibilities").

\subsubsection{SPR Cavern Shapes}

The following drawings (Figs. 12-14) represent our best estimate of cavern configurations within the Bryan Mound salt stock based on available information, includ- 
ing cavern leach and fill data, and sonar records. However, sonar plots were incomplete, because of the inability to obtain sonar in oil during leach and fill operations. Thus, some caverns are shown with dashed boundaries to show where known storage volume exists, but wall geometry is uncertain.

Figure 12 shows an isometric view of the southeast quadrant of the salt stock.

Figure 13 shows the two-dimensional configuration of the storage caverns.

Figure 14 shows isometric representations of the storage caverns.

\subsubsection{Cavern Integrity Issues}

\section{Cavern 1}

Cavern 1 is located well away from the edge of the dome but its closest approach to Cavern 4 is only $237 \mathrm{ft}$, less than now required of new caverns. Although geomechanical modeling analyses by Preece and Foley [1984] show that Cavern 1 is structurally sound, there is a likelihood of coalescence with Cavern 4 after two or three drawdowns. Such an eventuality would create an extremely large cavern and if joined with Cavern 5 would approach $100 \mathrm{MMB}$ (Figures 12, 14). However, the sonar and separation analysis of caverns following drawdowns should preclude such an eventuality from happening.

\section{Cavern 4}

Cavern 4 is the second largest cavern in the SPR system, with a volume of nearly 20.7 million barrels, exceeded only by Cavern 5 with 37.9 million barrels. A failure of the cemented casing in Well 4 at a depth of $789 \mathrm{ft}$ caused oil to first start leaking into the caprock in September of 1982, and eventually some 44,000 barrels escaped (POSSI, 1983). The first indication of a leak was a gradual loss of oil pressure, but brine had been removed from the cavern at about that time and the loss was attributed to it, causing diagnostic difficulty. Although the potential for oil escaping the caprock into the accessible environment was judged very low at the time, the loss of oil was problematic and the cause of concern, because it could affect other caverns as well.

This was the third failure of casing within the prior sulfur mining zone, demonstrating the short life of casing exposed to hot acidic water. The cemented casing string in Well 3 failed in the late 1950's, and in Well 2 in the mid-1970's. Drilling records from these wells were unavailable, so the degree of loss of cement while placing these cemented casing strings is unknown. Some of the difficulty no doubt is caused by incomplete cementing in loss zones, causing 


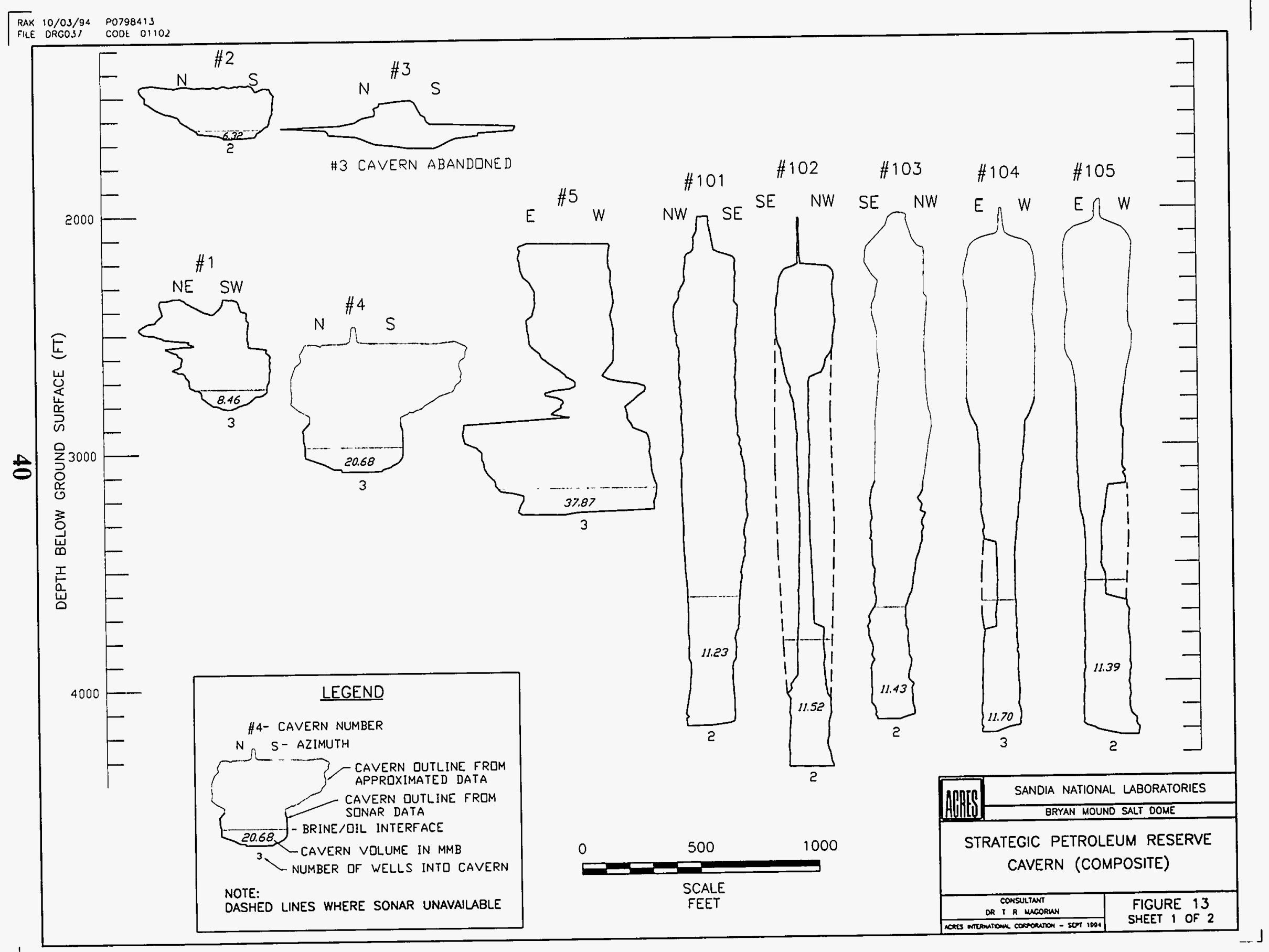




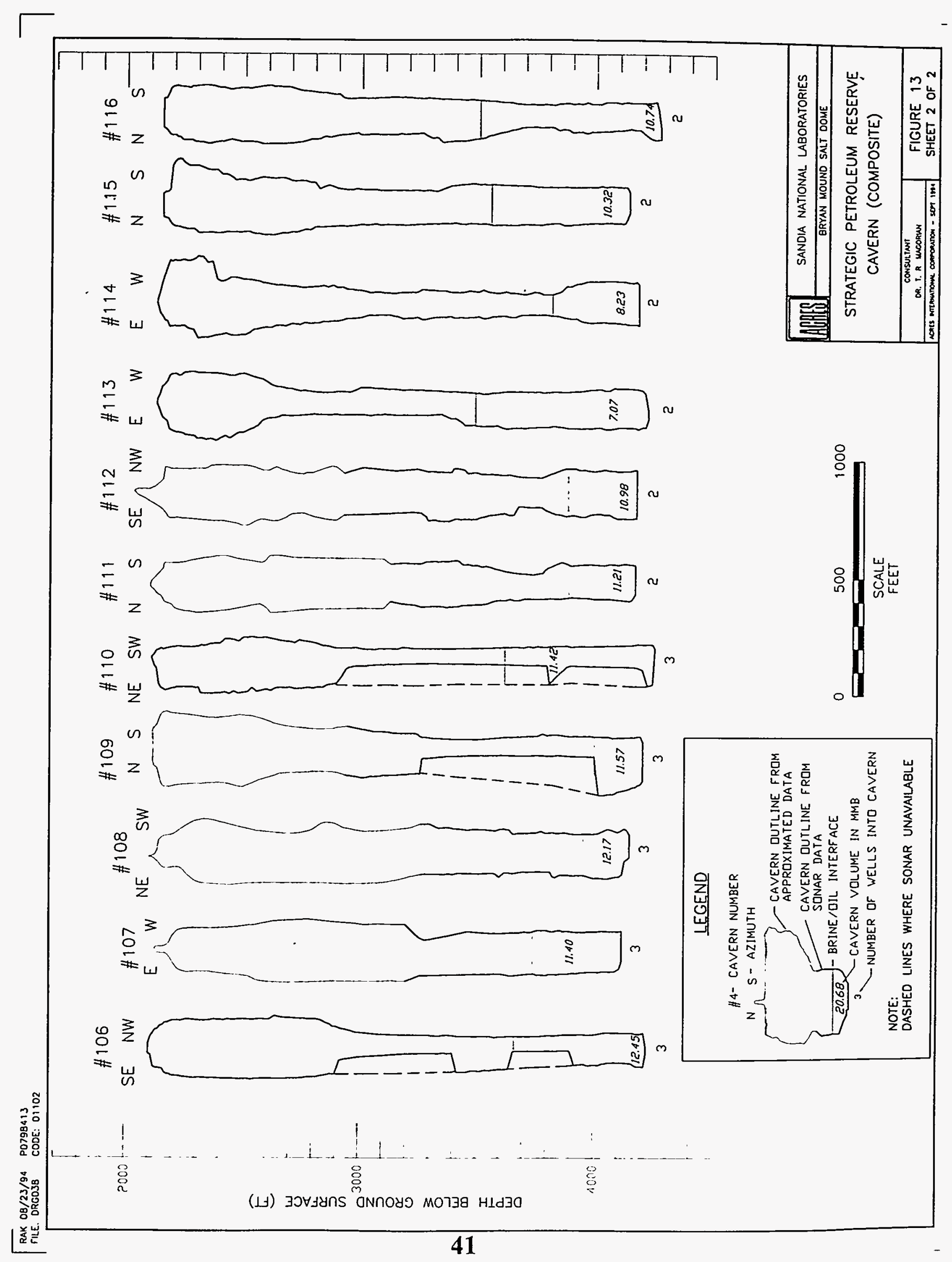

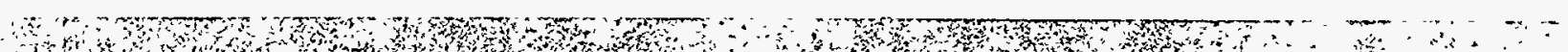




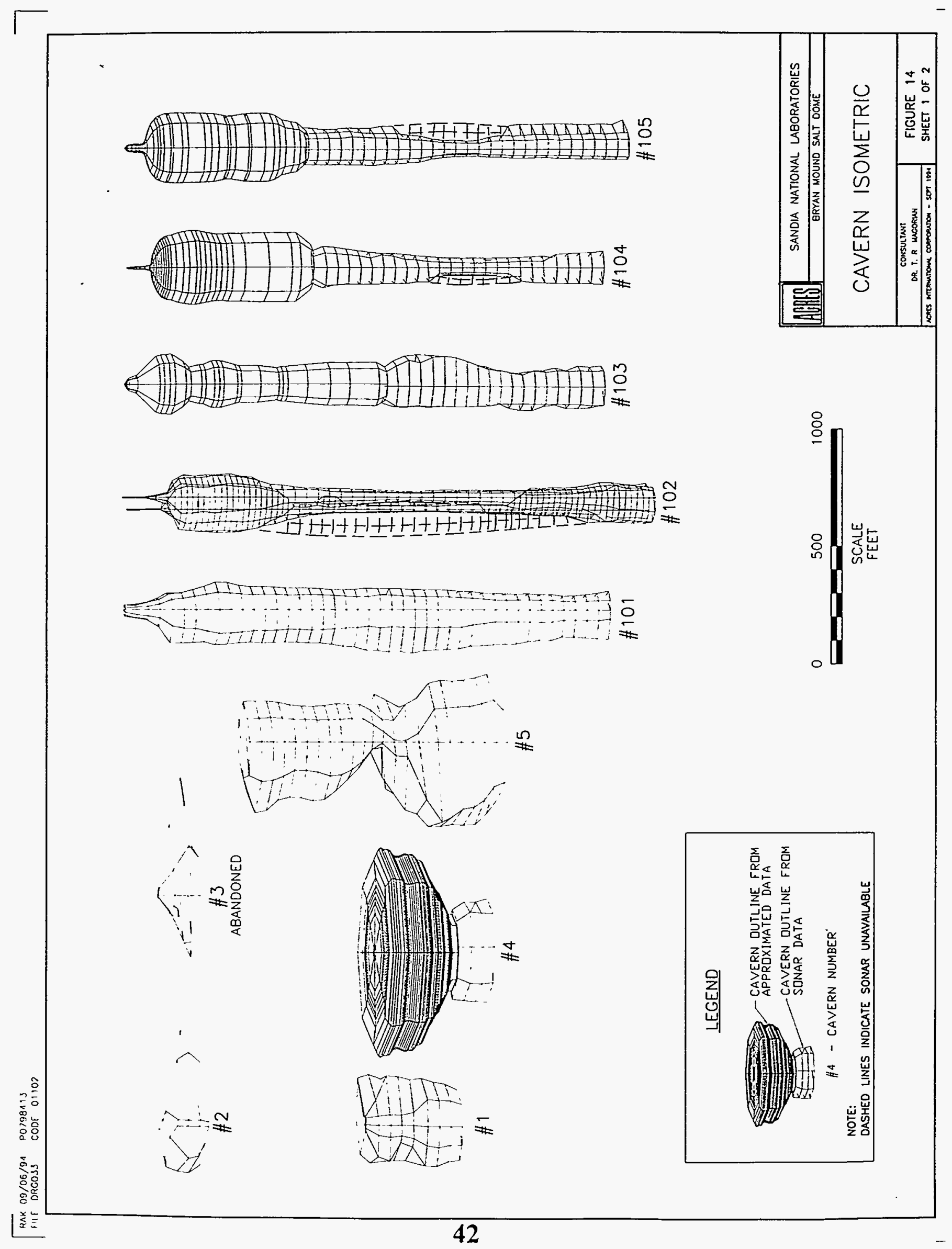




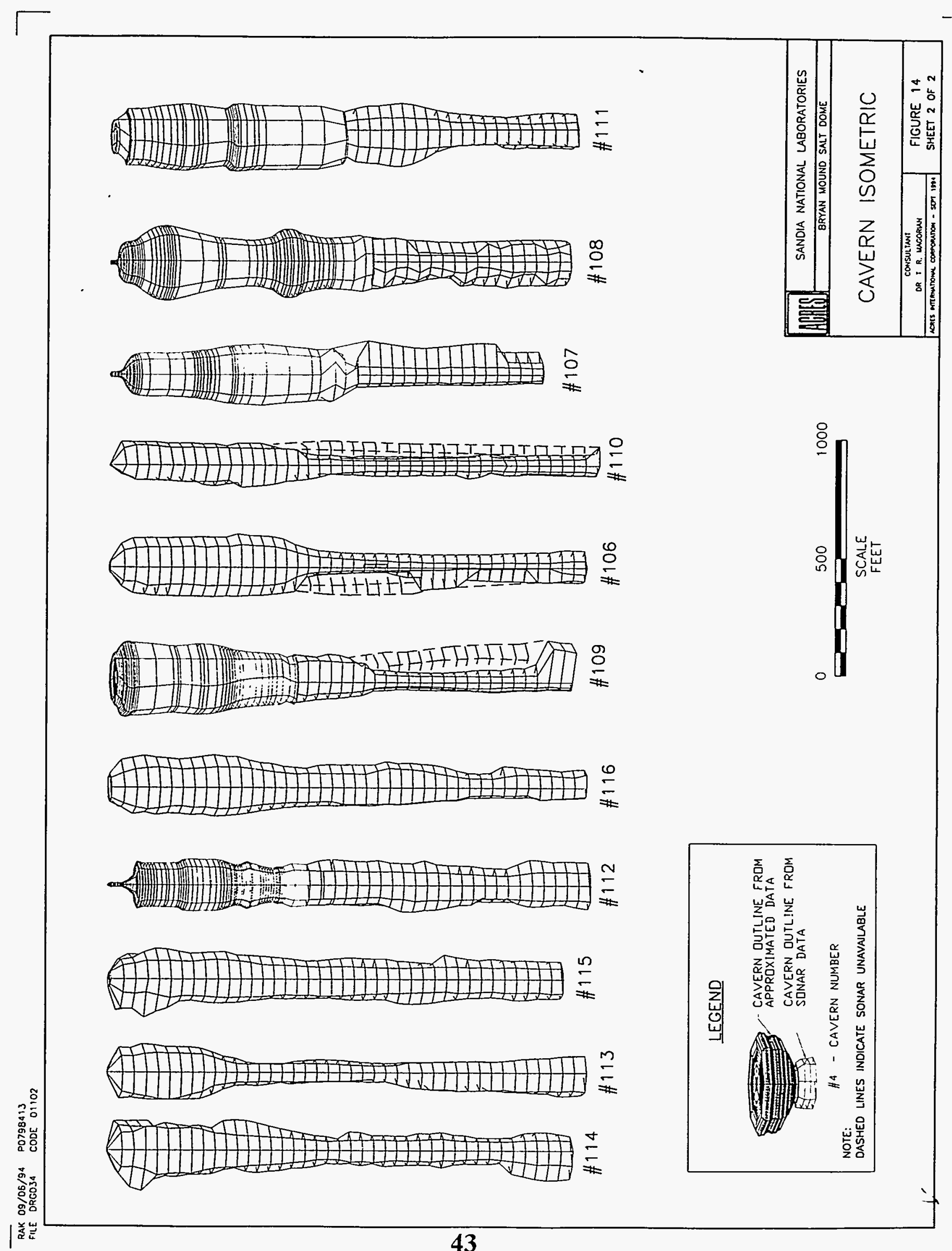


poor sealing. Well 4 was cemented and isolated from the cavern. Three Cavern 4 reentry wells, which had been constructed after SPR acquisition, remain. There has been no indication of other problems associated with this cavern (POSSI, 1983).

Although the wider-than-usual diameter of $504 \mathrm{ft}$ and short height of $581 \mathrm{ft}$ make for a stout shape, the geomechanical modeling of Preece and Foley [1984] suggest no structural problems, either present or future. The previously mentioned possibility for coalescence with Cavern 1 exists; this could create another super cavern, similar to Cavern 5 .

\section{Cavern 5}

Cavern 5 is a two-lobed cavern with a total volume of nearly 38 million barrels, the largest by far in the SPR inventory. Because of this very large volume, combined with an irregular shape and protruding edges, this cavern has been the center of many questions involving structural integrity. In addition, there is a zone of high anhydrite content that inhibited leaching of the narrow neck that separates the two lobes. Also, the brine string in Well 5 has been damaged at least four times by apparent salt falls, and/or shifting of material from the upper lobe.
Preece and Foley [1984] noted that substantial separation from both the edge (the $650 \mathrm{ft}$ distance has been increased to $1500 \mathrm{ft}$ in this revision) and the caprock $(1012 \mathrm{ft})$ enhanced the geomechanical environment for such a large cavern. Their analyses did not suggest any potential for instability, present or future, but they stated their model could not predict pillar stability during coalescence, or with underhanging wall projections.

An oil transfer was conducted in 1986 that leached the neck between the upper and lower cavern lobes, and also converted the cavern from sweet to sour oil storage. Leaching in April and May of 1986 created some 500,000 barrels of new space. This modification, along with additional leaching in June of 1987 which leached away the trap in the roof of the lower lobe, were aimed at improving structural integrity in the twolobed cavern [BPS, 1990]. However, since that time, there have been three incidents of presumed salt falls and associated damaged casing in Wells 5 and 5C.

The relative proximity of Cavern 5 to Caverns 4 and 1 was noted in the 1980 characterization. The enlargement of these caverns upon drawdown would create coalescence after 3-4 cycles; the interconnected 
gallery could have a combined volume approaching 100 million barrels (Figures 12, 14). The structural implications of such a large storage gallery have not been fully investigated, but are being considered at this time. As noted previously, the added proximity of Cavern 1 to Cavern 4 also must be considered. Mills (1994) notes that SPR Level II Criteria requires a study after every drawdown and that Cavern 5 would probably not be refilled if coalescence were possible during subsequent drawdown.

\section{Salt Falls and Hanging String Failures}

Since 1978 and continuing to the present, there have been some 37 incidents in which portions of hanging strings have been damaged or lost (Table 3). Most of them occurred during a static operating mode, but some occurred during leach/fill, and a few happened during depressurization or workovers, so all are not necessarily similar events. The problem is somewhat unique to Bryan Mound, even though similar incidents have occurred elsewhere. There have been several reasons advanced as to why these hanging string failures have occurred, including association with anomalous zones, excessive gas emission from within the salt, and the presence of $\mathrm{H}_{2} \mathrm{~S}$, possibly associated with the predominantly sour oil stored in these caverns. Corrosion as a contributing factor has been largely ruled out, as 1993 studies of metallurgy at the point of pipe joint failure in Cavern 107 showed no indications of corrosion due to hydrogen embrittlement. There appears to be no correlation of depth of failure with any other factor.

To date, a satisfactory answer to this puzzling condition has not been agreed upon, including whether salt is actually physically falling. However, the evidence for a majority of the incidents seems to support salt falling in some manner, even though it has not been proved [Mills, 1994]. Mills also cites other geotechnical distinctions about Bryan Mound which may have some bearing on the problem. There appears to be more heterogeneous salt, as shown in the more irregular Phase III caverns than those constructed at West Hackberry and Big Hill, for example. Some of the irregularities have been attributed to higher concentrations of sylvite, which typically leads to "wings" or unequal extensions in the caverns, often with preferred directional orientation. The stiffer, slower laboratory creep of Bryan Mound salt may also be a factor controlling large-scale mechanical behavior, according to Mills. $\mathrm{He}$ sees much slower transient response rates in Bryan Mound caverns following pressurization / depressurization. However, the manner in which these geotechnical distinctions 
Table 3 History of Bryan Mound Casing Failures ${ }^{1}$

\begin{tabular}{|c|c|c|c|c|c|c|c|}
\hline $\begin{array}{r}\text { Cavern } \\
\text { Well No. }\end{array}$ & $\begin{array}{l}\text { Cavern } \\
\text { Volume }\end{array}$ & $\begin{array}{c}\text { Date } \\
\text { Discovered } \\
\end{array}$ & $\begin{array}{l}\text { Activity/ } \\
\text { Failure }\end{array}$ & $\begin{array}{c}\text { Probable } \\
\text { Cause }\end{array}$ & $\begin{array}{c}\text { Casing } \\
\text { Lost }\end{array}$ & $\begin{array}{c}\text { Casing } \\
\text { Diameter }\end{array}$ & $\begin{array}{l}\text { Number } \\
\text { of Wells }\end{array}$ \\
\hline 5 & 37.50 & $10 / 78$ & $\overline{\text { Oil Fill }}$ & Anh. Slough & $\overline{456}$ & 9.625 & 3 \\
\hline 5 & 38.65 & $08 / 88$ & Static & Salt Fall & $204^{\prime}$ & 10.75 & 3 \\
\hline 5 & 38.65 & $06 / 90$ & Static & Salt Fall & $458^{\prime}$ & 10.75 & 3 \\
\hline $5 C$ & 34.05 & $07 / 92$ & Static & Salt Fall & $530^{\prime}$ & 9.625 & 3 \\
\hline 101C & 9.03 & $10 / 83$ & Leach/Fill & Salt Fall & $226^{\prime}$ & 13.375 & 2 \\
\hline 102B & 6.04 & $07 / 83$ & Leach/Fill & Salt Fall & $817^{\prime}$ & 13.375 & 2 \\
\hline 102B & 11.55 & $07 / 90$ & Static & Salt Fall & $747^{\prime}$ & 10.75 & 2 \\
\hline $103 C$ & 2.66 & $10 / 82$ & Workover & $\begin{array}{l}\text { Tbg. hung on } \\
\text { lip cement csg. }\end{array}$ & $4202^{\prime}$ & 13.375 & 2 \\
\hline $103 C$ & 10.25 & $12 / 83$ & Workover & $\begin{array}{l}\text { Csg. parted } \\
\text { plg. in sand }\end{array}$ & $3802^{\prime}$ & 13.375 & 2 \\
\hline $103 C$ & 11.68 & $08 / 87$ & Static & Salt Fall & $156^{\prime}$ & 13.375 & 2 \\
\hline $103 \mathrm{C}$ & 11.68 & $11 / 87$ & Static & Salt Fall & $343^{\prime}$ & 10.375 & 2 \\
\hline $103 \mathrm{C}$ & 11.68 & $10 / 90$ & Static & Salt Fall & $284^{\prime}$ & 10.75 & 2 \\
\hline 105B & 11.19 & $03 / 83$ & Oil Fill & $\begin{array}{l}\text { Undrwt. csg./ } \\
\text { brine in oil }\end{array}$ & $2377^{\prime}$ & 13.375 & 2 \\
\hline 106A & 12.53 & $05 / 86$ & Depressure & Salt Fall & $1027^{\prime}$ & 10.75 & 3 \\
\hline $106 \mathrm{C}$ & 12.25 & $01 / 88$ & Static & Salt Fall & $3340^{\prime} \mathrm{Dm}$ & 10.75 & 3 \\
\hline 106A & 12.53 & $07 / 90$ & Static & Salt Fall & $3400^{\prime} \mathrm{Dm}$ & 10.75 & 3 \\
\hline 106A & 12.53 & $03 / 91$ & Static & Salt Fall & $1080^{\prime}$ & 10.75 & 3 \\
\hline $106 \mathrm{C}$ & 12.53 & $04 / 91$ & Static & Salt Fall & $1238^{\prime}$ & 10.75 & 3 \\
\hline 106A & 12.45 & $05 / 92$ & Static & Salt Fall & $561^{\prime}$ & 10.75 & 3 \\
\hline $106 \mathrm{C}$ & 12.45 & $05 / 92$ & Static & Salt Fall & $431^{\prime}$ & 10.75 & 3 \\
\hline $107 \mathrm{C}$ & 11.50 & $08 / 84$ & Static & Salt Fall & 1232 & 10.75 & 3 \\
\hline 107B & 11.50 & $09 / 84$ & Static & Salt Fall & Damage & 10.75 & 3 \\
\hline $107 \mathrm{~A}$ & 11.50 & $06 / 86$ & Depressure & Salt Fall & $297^{\prime}$ & 10.75 & 3 \\
\hline 107A & 11.53 & $04 / 89$ & Static & Salt Fall & $3174^{\prime}$ & 10.75 & 3 \\
\hline 107A & 10.18 & $06 / 92$ & Static & Salt Fall & $1125^{\prime}$ & 10.75 & 3 \\
\hline 107A & 10.18 & 09/93 & Workover & Salt Fall & @3500' & 10.75 & 3 \\
\hline $107 \mathrm{C}$ & 10.18 & $09 / 93$ & Workover & Salt Fall & @3100' & 10.75 & 3 \\
\hline 108A & 9.28 & $04 / 84$ & Leach/Fill & Salt Fall & $767^{\prime}$ & 10.75 & 3 \\
\hline 108B & 9.28 & $04 / 84$ & Leach/Fill & Salt Fall & $41^{\prime}$ & 10.75 & 3 \\
\hline 108B & 12.24 & $01 / 87$ & Static & Salt Fall & $620^{\prime}$ & 10.75 & 3 \\
\hline $109 \mathrm{C}$ & 10.94 & $07 / 83$ & Leach/Fill & Salt Fall & $97^{\prime}$ & 10.75 & 3 \\
\hline 109B & 11.60 & $11 / 84$ & Static & Salt Fall & $305 /$ & 10.75 & 3 \\
\hline 109A & 11.62 & $11 / 87$ & Static & Salt Fall & $268 "$ & 10.75 & 3 \\
\hline $112 \mathrm{~A}$ & 11.21 & $08 / 85$ & Static & Salt Fall & $769^{\prime}$ & 10.75 & 2 \\
\hline $112 \mathrm{~A}$ & 11.07 & $12 / 86$ & Static & Salt Fall & $1371^{\prime}$ & 10.75 & 2 \\
\hline $112 \mathrm{~A}$ & 11.07 & $06 / 89$ & Static & Salt Fall & $1304^{\prime}$ & 10.75 & 2 \\
\hline $112 \mathrm{~A}$ & 11.07 & $11 / 90$ & Static & Poss.Salt Fl. & $992^{\prime}$ & 10.75 & 2 \\
\hline $112 \mathrm{~A}$ & 9.64 & $01 / 93$ & Static & Salt Fall & 1563 & 10.75 & 2 \\
\hline
\end{tabular}

'Hushang Bakhtiari. DynMcDermott: Cavern Engineering Report, 09 April 93; Note: "this list does not count casing cuts to reposition the string depth." 
result in more presumed salt falls is unknown. Many have thought that three-well caverns created salt walls that were more conducive to falling salt, as fully two-thirds of the incidents occurred in them (Table 4). However, even if that is a causative factor, the remaining one-third of the incidents in two-well caverns is still excessive and anomalous with respect to the other SPR sites.

The possible association with anomalous zones is ambiguous, as is the correlation with gassy oil, discussed in the following section. Thoms (in Neal, et al., 1993) has plotted those caverns with salt falls; it reveals two discrete bands or zones separated by a central zone (consisting of Caverns 1, 2, 3, 4,104 , and 105) that is virtually devoid of salt falls, and relatively less gassy oil accumulation. This clustering suggests a possible geologic association, as patterns such as these could manifest a lobe or zone with specific properties. However, nothing of a geologic nature was recognizable that would suggest any associations involving the particular caverns identified in Table 3, but casing failures should be expected to continue preferentially in them. The economic penalty of continuing salt falls appears to provide the incentive for additional study of causative factors. A program to monitor pressure fluctuations that might indicate salt falls was being considered in mid-1994.

\section{Gas in Oil}

In early 1993 it was learned that a number of caverns within the SPR system had excessive amounts of gaseous hydrocarbons dissolved in the oil. The oil would require degassing prior to refining in many cases, and because the processing rate may be less than the drawdown rate criteria, cycling of oil and concomitant degassing is anticipated in order to maintain readiness [Oil and Gas Journal, 1993, 1994].

In a number of instances the gas content had increased, leading to the conclusion that the source originated from within the salt [Hinkebein, et al., 1994]. Gas in salt has long been a problem in conventional mining, leading to several fatal accidents following outbursts of gas and associated saltfalls [Molinda, 1988]. At Bayou Choctaw, Caverns 18 and 20 showed higher than allowable gas content in March and May, 1993, and were identified as requiring treatment prior to drawdown. A possible correlation of gassy caverns and a $\mathrm{N} 75^{\circ} \mathrm{E}$ trending shear zone which transects the dome may exist; a similar N $45^{\circ} \mathrm{W}$ shear zone occurs at Bryan Mound [Thoms, 1993]. The apparent corre- 
Table 4 Correlation of Salt Falls with Numbers of Wells and Chimneys *

\begin{tabular}{|c|c|c|c|c|}
\hline Cavern & \#Wells & $\underline{\text { Salt Falls }}$ & \# Chimneys & Remarks \\
\hline 101 & 2 & 1 & 2 & \\
\hline 102 & 2 & 2 & 2 & \\
\hline 103 & 2 & 3 & 2 & anomalously high gas content \\
\hline 104 & 3 & 0 & 3 & \\
\hline 105 & 2 & 0 & 2 & \\
\hline 106 & 3 & 7 & 3 & \\
\hline 107 & 3 & 7 & 3 & \\
\hline 108 & 3 & 3 & 2 & \\
\hline 109 & 3 & 3 & 2 & \\
\hline 110 & 3 & 0 & 3 & \\
\hline 111 & 2 & 0 & 1 & anomalously high gas content \\
\hline 112 & 2 & 5 & 1 & anomalously high gas content \\
\hline 113 & 2 & 0 & 1 & \\
\hline 114 & 2 & 0 & 1 & high gas content \\
\hline 115 & 2 & 0 & 1 & \\
\hline 116 & 2 & 0 & 1 & high gas content \\
\hline
\end{tabular}

Notes: (1) Cavern 5 excluded from statistics (leached with 1 well, then operated with 3 )

(2) 5 salt falls damaged both strings at once, totalling 10 damaged strings

\section{Summary of Table 4:}

\section{Of 31 Strings Damaged by Salt Falls:}

14 occurred in the 4 caverns with 3 chimneys ( $14 / 4=3.5$ per cavern) 12 occurred in the 6 caverns with 2 chimneys ( $12 / 6=2.0$ per cavern) 5 occurred in the 6 caverns with 1 chimney $(5 / 6=0.83$ per cavern)

Better correlation with number of wells:

20 occurred in the 6 caverns with 3 wells $(20 / 6=3.3$ per cavern) 11 occurred in the 10 caverns with 2 wells $(11 / 10=1.1$ per cavern $)$ Two 3-well caverns had no salt falls

* This summary was provided by Ken Mills, DynMcDermott (1994) 
lation with the anomalous zone (AZ) at Bayou Choctaw may be similar to that noted by Iannacchione et al. [1984] in his study of gas associated with salt outbursts in conventional mining. This correlation suggests that gas migrates through these AZs and into the adjacent salt at a faster rate than in normal salt. At Bayou Choctaw Caverns 18 and 20 are evidently in the salt adjacent to the AZ. As noted earlier, Cavern 20 is also located near the edge of the salt and adjacent to gasproducing sands. The rate of increase in gas content in these two caverns at Bayou Choctaw is uncertain.

At Bryan Mound there are ten caverns showing marginal to excessive gas in oil ratios, virtually half of the inventory. Six Caverns $(2,5,103,111,112,114$, and 116), have the highest historical intrusion rates and are estimated to continue to have problematic intrusion rates in the future [Hinkebein et al., 1994]. Three caverns, \#s 5, 103, and 112 , also have had a history of apparent salt falls and concomitant casing loss, which is discussed in the preceding section. The correlation of Bryan Mound caverns having ex- cess gas with specific geologic features is uncertain, but some indications are evident and may be tested further in future studies. Figure 2 (p. 10-11) shows the location of two intersecting anomalous zones, trending $\mathrm{N} 45^{\circ} \mathrm{W}$ and $\mathrm{N} 17^{\circ} \mathrm{E}$, the latter labeled as a possible AZ. The six caverns identified above, excepting \#116, are all within a few hundred feet of these AZs at the surface, but the subsurface extent is not well understood. Cavern 116 is located near the periphery, similar to Bayou Choctaw Cavern 20 and that may be factor that facilitates greater gas intrusion. However, at least eight other caverns are equally as close to the AZs and do not contain similar excessive gas intrusion rates, thus ambiguity exists and this provisional correlation may have questionable validity. The concept of anomalous zones in salt domes has evolved over the past forty years or so and is based on a very limited number of observations, mostly within underground mines, and even then in only a few domes with limited areal extent [Neal et al., 1993]. For these reasons, the understanding of gas in salt may require substantial study to arrive at definitive origins. 


\subsection{Subsidence}

Groundwater and/or oil withdrawal has created localized subsidence depressions around Houston and Freeport ranging up to nearly ten, and more than two feet, respectively [Gabrysch, 1982]. Bryan Mound is on the western periphery of the Freeport subsidence bowl, which resulted largely from the pumping of ground water from municipal and industrial wells less than 500 feet deep. The depression could affect surrounding lowland areas and create flooding problems if it were to intensify. There has been no new subsidence data since the 1982 Gabrysch report in the Freeport area; it is outside of the areas of major concern in Harris (Houston) and Galveston counties. Neither subsidence nor groundwater measurements are anticipated in the future, according to United States Geological Survey personnel [Barbie, 1993]. Significantly, Freeport stopped using groundwater for municipal supplies in 1988 [Shipp, 1993], relying entirely on surface water from the Brazosport Water Authority. As a result, the groundwater environment has again been altered and will further affect regional subsidence rates, if not curtailing them.

A consequence of the very intensive pumping of ground water in the greater
Houston area has been subsidence and associated surface displacement along growth faults. Numerous small scarps of $1-2 \mathrm{ft}$ in height have caused extensive damage to homes and businesses and required extensive repairs and/or demolition. The conversion from ground to surface water as a source of municipal supply in East Houston has significantly reduced the subsidence and associated faulting, thus establishing a positive correlation between the two phenomena [Holzer and Gabrysch, 1987]. The amount of subsidence in Freeport is substantially less than at Houston, and because of the cessation of ground water use for municipal and industrial use, is essentially arrested. Induced activation of growth faults such as in Houston appears much less likely to occur, but could be a problem affecting oil and/or brine pipeline integrity. Ground-water levels taken between 1968-1989 in five municipal and industrial wells within the Freeport subsidence basin were examined and none showed declining water levels. This shows that withdrawals were being exceeded by recharge and that the subsidence depression was likely caused by pre-1968 water declines. Gabrysch [1993] reports that 1942 levels were substantially above depths of 
$50 \mathrm{ft}$, confirming that the subsidence depression is largely a product of the 1940s and 50s

The Bryan Mound subsidence network has been tied to reference benchmark USC\&GS 1274 at the corner of the Velasco Street Bridge in Freeport, using the same elevation in 1992 as was used in 1978 $\left(16.96^{\prime}\right)$. Because the Freeport subsidence basin may have been altered as groundwater continued to be extracted (until 1988), this benchmark, located near the center of the subsidence bowl, may also have been affected, but at the very least, is of questionable accuracy. The National Geodetic Survey (NGS) indicates they do not relevel these monuments routinely unless there is a major project or other reason to do so. Gabrysch [1993] points out there was an instrumental error (involving the Zeiss NI-1 level) that was experienced by the NGS in the 1970s. Consequently the data from Bryan Mound are likely invalid in an absolute sense, but they still may accurately show the relative subsidence effects between the land surface over the caverns and that in downtown Freeport. But any additional subsidence occurring over the Freeport subsidence bowl would be reflected in that measured over the caverns; thus an erroneous, lesser value of subsidence than actually is occurring may have been reported.
Survey data are somewhat inconclusive because of the very low rates, for the reasons explained above, and because the maximum allowable survey error $(17.2 \mathrm{~mm})$ is likely greater than the presumed subsidence. Virtually all of the stations show less than one-half of one foot total subsidence for a ten year period. However, McHenry [1992] cautions that the 1985-1990 data are less accurate than more recent data. Table 5 shows elevation change at selected subsidence stations. Of these stations the range is from 0.002 to $.068 \mathrm{ft} / \mathrm{yr}(1-21 \mathrm{~mm} / \mathrm{yr})$, for an average of $0.036 \mathrm{ft} / \mathrm{yr}(1 \mathrm{~mm} / \mathrm{yr})$. The higher and lower values are sufficiently skewed from the other values so as to be questionable. There is also very little spread in the data from point to point, so that meaningful patterns or contouring are impractical. The data in Table 4 excluded three previous surveys going back to 1982 which contained a presumed systematic error; however, there are no inconsistencies in either data set when a systematic correction is assumed.

A few conclusions can be reached, however tentative, based on these observations and the understanding of subsidence at other SPR sites: The subsidence data obtained at Bryan Mound between 1982 and 1994 show very low overall averages; in fact they are the lowest of all the SPR sites. A contradiction in the intuitive understanding 
Table 5 Elevation Change at Selected Subsidence Stations, 1985-1994

\begin{tabular}{|c|c|c|c|c|c|c|c|c|c|c|c|}
\hline$\underline{\text { Station }}$ & $\underline{3 / 85}$ & $\underline{11 / 86}$ & $\underline{9 / 87}$ & $\underline{12 / 88}$ & $\underline{1 / 90}$ & $\underline{2 / 91}$ & $\underline{1 / 92}$ & $\underline{12 / 92}$ & $\underline{4 / 94}$ & $\underline{\Delta}$ & feet/year \\
\hline $6 \mathrm{C}$ & 19.12 & 19.00 & 19.00 & 19.00 & 18.92 & 18.85 & 18.61 & 18.61 & $\overline{18.50}$ & 0.62 & .068 \\
\hline $7 \mathrm{~A}$ & 10.87 & 10.78 & 10.80 & 10.78 & 10.69. & 10.63 & 10.56 & 10.51 & 10.48 & 0.39 & .043 \\
\hline $8 B$ & 10.82 & 10.84 & 10.84 & 10.88 & 10.83 & 10.74 & 10.66 & 10.62 & 10.58 & 0.24 & .026 \\
\hline $9 \mathrm{C}$ & 8.94 & 8.84 & 8.87 & 8.89 & 8.81 & 8.74 & 8.69 & 8.62 & 8.59 & 0.35 & .039 \\
\hline $10 \mathrm{~A}$ & 8.78 & 8.69 & 8.72 & 8.71 & 8.64 & 8.58 & 8.49 & 8.46 & 8.43 & 0.35 & .039 \\
\hline $11 \mathrm{~A}$ & 23.77 & 23.72 & 23.72 & 23.73 & 23.71 & 23.65 & 23.55 & 23.58 & 23.51 & 0.26 & .029 \\
\hline $12 \mathrm{C}$ & NA & 9.82 & 9.87 & 9.88 & 9.79 & 9.73 & 9.62 & 9.71 & 9.59 & 0.23 & .031 \\
\hline $13 \mathrm{~A}$ & 9.54 & 9.45 & 9.44 & 9.49 & 9.41 & 9.47 & 9.28 & 9.26 & 9.21 & 0.33 & .036 \\
\hline BM2 & 16.95 & 16.92 & 16.85 & 16.83 & 16.79 & 16.71 & 16.67 & 16.63 & 16.52 & 0.43 & .047 \\
\hline BM4 & 14.28 & 14.14 & 14.14 & 14.18 & 14.12 & 14.05 & 13.98 & 13.94 & 13.88 & 0.40 & .044 \\
\hline BM5 & 7.55 & 7.46 & 7.46 & 7.51 & 7.44 & 7.38 & 7.33 & 7.31 & 7.24 & 0.31 & .034 \\
\hline BM101C & 6.53 & 6.40 & 6.44 & 6.51 & 6.45 & 6.73 & 6.34 & 6.34 & 6.26 & 0.27 & .030 \\
\hline BM102C & 6.11 & 6.06 & 6.09 & 6.13 & 6.11 & 6.06 & 6.01 & 5.98 & 5.94 & 0.17 & .019 \\
\hline BM103C & 6.52 & 6.44 & 6.48 & 6.56 & 6.52 & 6.49 & 6.42 & 6.43 & 6.39 & 0.13 & .014 \\
\hline BM104C & 10.29 & 10.22 & 10.22 & 10.26 & 10.19 & 10.13. & 10.05 & 10.06 & 9.99 & 0.30 & .033 \\
\hline BM105C & 12.83 & 12.75 & 12.71 & 12.80 & 12.74 & 12.86 & 12.62 & 12.61 & 12.56 & 0.27 & .030 \\
\hline BM106A & 15.83 & 15.73 & 15.76 & 15.79 & 15.70 & 15.64 & 15.57 & 15.53 & 15.49 & 0.34 & .037 \\
\hline BM107C & 15.59 & 15.46 & 15.51 & 15.54 & 15.45 & 15.38 & 15.30 & 15.28 & 15.22 & 0.37 & .041 \\
\hline BM108A & 15.98 & 15.88 & 115.85 & 15.95 & 15.87 & 15.80 & 15.75 & 15.72 & 15.66 & 0.32 & .035 \\
\hline BM109C & 15.88 & 15.79 & 15.81 & 15.82 & 15.76 & 15.70 & 15.62 & 15.60 & 15.54 & 0.34 & .037 \\
\hline BM110B & 15.77 & 15.69 & 15.70 & 15.68 & 15.63 & 15.56 & 15.51 & 15.47 & 15.37 & 0.40 & .044 \\
\hline BM111B & 6.59 & 6.58 & 6.59 & 6.65 & 6.65 & 6.60 & 6.72 & 6.74 & 6.57 & 0.02 & .002 \\
\hline BM112A & 11.51 & 11.36 & 11.32 & 11.30 & 11.37 & 11.31 & 11.14 & 11.11 & 11.07 & 0.44 & .048 \\
\hline BM113A & $\mathrm{NA}$ & $\mathrm{NA}$ & NA & NA & NA & NA & 8.31 & 8.30 & 8.22 & 0.09 & .040 \\
\hline BM114A & $\mathrm{NA}$ & NA & NA & NA & NA & NA & 9.37 & 9.33 & 9.30 & 0.07 & .031 \\
\hline BM115A & NA & NA & NA & NA & NA & NA & 11.24 & 11.21 & 11.16 & 0.08 & .036 \\
\hline BM116A & NA & $\mathrm{NA}$ & NA & $\mathrm{NA}$ & NA & NA & 7.31 & 7.27 & 7.23 & 0.08 & .036 \\
\hline SMS1 & 8.55 & $\mathrm{NA}$ & 8.50 & 8.49 & 8.45 & 8.39 & 8.32 & 8.29 & 8.23 & 0.32 & .035 \\
\hline SMS5 & 15.82 & $\mathrm{NA}$ & 15.72 & 15.70 & 15.65 & 15.59 & 15.53 & 15.48 & 15.42 & 0.40 & .044 \\
\hline SMS9 & 11.59 & NA & 11.47 & 11.51 & 11.44 & 11.37 & 11.30 & 11.28 & 11.22 & 0.37 & .041 \\
\hline SMS10 & 11.79 & NA & 11.86 & 11.89 & 11.84 & 11.78 & 11.71 & NA & 11.63 & 0.16 & .018 \\
\hline SMS12 & 9.15 & $\mathrm{NA}$ & 9.04 & 9.08 & 9.01 & 8.95 & 8.88 & 8.87 & 8.80 & 0.35 & .039 \\
\hline SMS13 & 11.11 & 11.00 & 11.00 & 11.03 & 10.96 & 10.90 & 10.84 & 10.80 & 10.74 & 0.37 & .041 \\
\hline SMS19 & 6.51 & 6.44 & 6.46 & 6.50 & 6.44 & 6.38 & 6.29 & 6.30 & 6.23 & 0.28 & .031 \\
\hline SMS20 & 8.83 & 8.75 & 8.76 & 8.80 & 8.73 & 8.67 & 8.61 & 8.59 & 8.51 & 0.32 & .035 \\
\hline SMS25 & 8.86 & 8.75 & 8.78 & 8.79 & 8.74 & 8.68 & 8.58 & 8.58 & 8.52 & 0.34 & .037 \\
\hline SMS28 & 7.84 & 7.73 & 7.75 & 7.80 & 7.72 & 7.66 & 7.60 & 7.55 & 7.52 & 0.32 & .035 \\
\hline SMS29 & 10.43 & 10.33 & 10.30 & 10.36 & 10.30 & 10.24 & 10.18 & 10.15 & 10.09 & 0.34 & .037 \\
\hline SMS31 & 6.32 & 6.24 & 6.23 & 6.30 & 6.23 & 6.17 & 6.11 & 6.11 & 6.04 & 0.28 & $\begin{array}{l}\frac{.031}{\sum=} \\
14.08 \\
r)\end{array}$ \\
\hline
\end{tabular}

$\mathrm{NA}=$ data not available

Note: Stations $6 \mathrm{C}$ and $111 \mathrm{~B}$ are sufficiently skewed from other values so as to be questionable 
of subsidence exists, considering that Bryan Mound has the largest cavern volume of all the sites; thus greater cavern creep closure might be expected. For example, West Hackberry has the highest rate, some eight times that at Bryan Mound, and with an equivalent (although slightly higher) total cavern volume for the whole dome. The possible cause of this disparity may lie in much lower salt creep rates in Bryan Mound salt [Wawersik and Zeuch, 1984] and in the somewhat deeper caverns at West Hackberry [Neal, 1991].

Subsidence effects related to the size of the dome were modeled by Hoffman and Ehgartner [1993], using a 3-D finite element model of a 7-Cavern storage field similar in geometry to SPR caverns. Dome diameters of $2.0,1.0$, and 0.5 miles were examined, and corresponding volume losses of 5.2, 3.9, and 2.5 percent were predicted for the relatively small 7-cavern facility at $30 \mathrm{yrs}$, respectively. A larger cavern field, such as at Bryan Mound, would also experience de- creases in storage losses as the dome diameter decreases. In comparison to West Hackberry (dome diameter greater than 2 miles), the storage losses at Bryan Mound (dome diameter approximately one mile) should be significantly less because of its smaller dome size and harder salt (slower creep rate). This hypothesis could be tested by relative comparisons of deep survey monuments tied to salt.

The most serious effect of subsidence near coastal areas, and in particular at Bryan Mound, is additional loss of already low elevation, which makes the susceptibility to hurricane surge a greater threat. Because of the apparent very low subsidence rates occurring at Bryan Mound, and because the local subsidence caused by excessive ground water pumping has largely been curtailed, subsidence is not an issue of significance at this time. However, because of the uncertainties cited above, continuing surveillance is essential.

\section{$\underline{3.3 \quad \text { Flooding }}$}

There is little that is new which would significantly change the 1980 evaluation of flood conditions at Bryan Mound. Subsidence has been sufficiently low so that site 
vulnerability has not changed appreciably, even though the location is very near the coast. The major flood threat is from overland surge during hurricanes and that threat model has not changed. Calculations by the Corps of Engineers suggest that surge heights of $10 \mathrm{ft}$ can be expected along the coast 2.5 times per 100 years and that maximum surge height is $13 \mathrm{ft}$ [Bodine, 1969]. However, the estimated change in water surge elevation between the coast and the Bryan Mound site was five feet, recorded during what was estimated to be a near- 100 yr event (the August, 1915 hurricane). Thus, according to this data and for that kind of event, the high-water mark during extreme storm events is apt to be less than $10 \mathrm{ft}$, and as low as $8 \mathrm{ft}$ above mean sea level for the $100 \mathrm{yr}$ event. The values for $500 \mathrm{yr}$ flood events are typically only slightly higher than 100 yr events. The FEMA estimates, reproduced in (Figure 15), show a $3 \mathrm{ft}$ drop in elevation from 15 to 12 feet between the coast and a location between the Intracoastal Waterway and Bryan Mound during a $100 \mathrm{yr}$ event. This information, along with a maximum coastal water elevation of $14 \mathrm{ft}$ (presumably a conservative upper value), would translate to a predicted high water elevation at Bryan Mound in the 10-12 ft range. In addition, wave crests could add to this maximum elevation range.

During the 1961 Hurricane Carla, also considered to be a near-100 yr event, the highest recorded surge elevation along the Texas coast was $12.3 \mathrm{ft}$, near Freeport. Minimum dike heights for the Bryan Mound area are $17.5 \mathrm{ft}$ and the dike passes through the site, taking advantage of the higher elevations on the dome. This higher elevation and the flood levee would protect much of the dome during $500 \mathrm{yr}$ flood events (from hurricane surges; see Figure 15). However, this still leaves 11 caverns (with aggregate storage volume exceeding $100 \mathrm{MMBBL}$ ) south of the protection levee, so that temporary flooding can be anticipated during hurricanes that have significant overland surge. As a consequence, temporary shutdowns must be anticipated.

As part of the FEMA Flood Insurance Study for Brazoria County [FEMA, 1993], a frequency analysis showed computed flood elevations and tidal surge heights (stillwater elevations) associated with various returnperiod storm events. This analysis predicted the following stillwater elevations in the Bryan Mound area: 


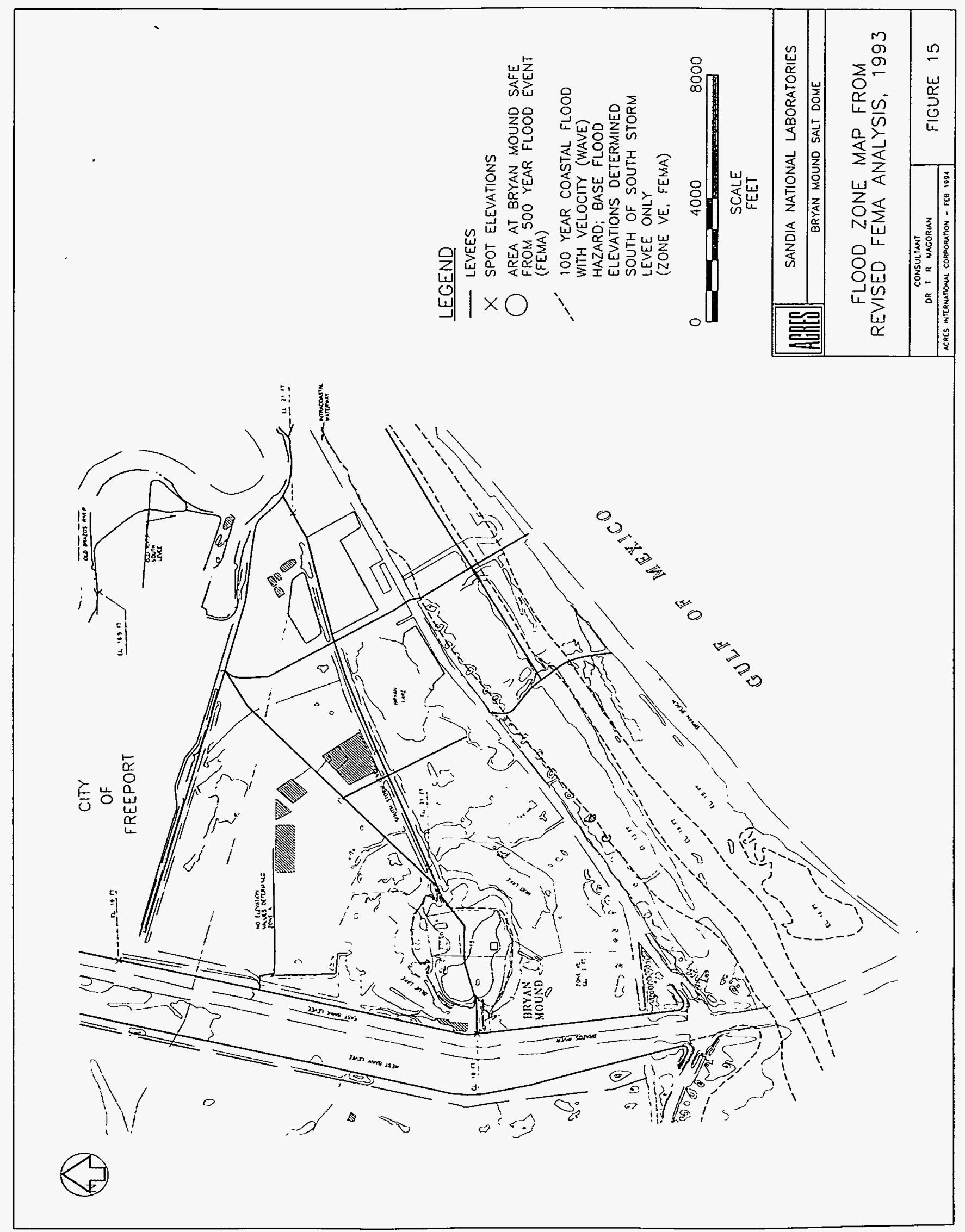

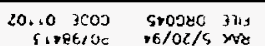




\section{Return Period, Years}

10

50

100

500

\section{Stillwater Elevation, Feet}

\section{$5-5.5$}

8.9-9.8

$10.0-11.0$

$12.1-13.1$
The FEMA flood insurance zones around Bryan Mound show the area south of the South Storm Levee classified as Zone $\mathrm{VE}$, characterized as 100-yr coastal flood plain having additional storm-wave hazards. Whole-foot base flood elevations derived from the FEMA analysis are shown on Figure XX. The area north of the South Storm Levee is classified as Zone A, indicating that base flood elevations have not been determined.

Speculation on increased hurricane frequency was rampant following the summer 1992 occurrence of three major hurricanes in 19 days affecting the United States and its territories. There is lack of agreement on cyclical trends, but there is general agreement among atmospheric physicists that warmer oceans will increase severity of tropical storms, and probably the frequency [Emanuel, 1988]. Thus, understanding of greenhouse warming trends, if real, has implications on tropical storm generation, and consequent flooding effects. Should hurri- cane trend changes be noted, flood frequency determinations will need to be reexamined.

\subsubsection{Projected Loss of Coastal Shore- lines}

Whereas Louisiana has undergone continuing, progressive loss of its coastal marshlands in this century, Texas is far less vulnerable in this regard, experiencing nowhere near the rate of loss [Morton and Pieper, 1975; Paine and Morton, 1989]. Surface elevations, sediment types, and geologic conditions are generally more favorable with respect to coastal erosion than in Louisiana, but are apparently highest in Texas just west of Freeport. Measurements of coastal retreat adjacent to Bryan Mound are very low, on the order of $15 \mathrm{ft}$ per year. Measurements west of the New Brazos River by the Army Corps of Engineers [Tanner, 1991] near Sargent (15 miles west of Bryan Mound) showed rates of $30 \mathrm{ft} / \mathrm{yr}$, which would be about a kilometer / century. Subsidence rates in this vicinity are also very low. The Corps of Engineers is currently 
planning a massive concrete structure along some 10 miles of the Intracoastal Waterway in this vicinity, and has as its goal to preserve the integrity of all land north of the Intracoastal. There has not been a need perceived for such works of engineering in the immediate vicinity of Bryan Mound.

Paine and Morton [1989] reported that shoreline near the Freeport jetties just east of Bryan Beach retreated more slowly than shoreline near the new Brazos delta, despite the Brazos discharge. Retreat rates near the Freeport Jetties were slower between 1956 and 1974 than between 1930 and 1956 and continued to decline between 1974 and 1982 , ranging from 3.1 to $9.7 \mathrm{ft} / \mathrm{yr}$ as the shoreline became more linear. Just three miles southwest of the new Brazos River, the San Bernard River flows into the Gulf and is rapidly prograding new delta at rates exceeding $100 \mathrm{ft} /$ year

These historical shoreline data show that the Bryan Beach area is stable at this time and is probably experiencing very slow, if any, shoreline loss at this time. Thus, the Bryan Mound dome is unaffected by any threat of shoreline erosion.

\section{$\underline{3.4 \quad \text { Seismicity }}$}

The 1980 site characterization report [Hogan et al., 1980] noted that nearly all of the faults defined on the Texas Gulf Plain are "growth" faults, which generally are considered to be aseismic. That is, they are not in the same class of faults that originate in deep-seated tectonic processes, but rather result from gravity sliding. In Houston, many growth faults have shown reactivation during the 1960's and 70's, presumably as a consequence of intensive ground water withdrawal and associated subsidence [Davis et al., 1989; Verbeek, E. R., 1979]. The mo- tion on these faults is essentially aseismic, and surface displacements occur as a result of gradual creep of subsurface sediments, rather than sudden strain release normally associated with earthquakes. The potential for the reactivation of movement along growth faults in the Freeport area has been considered and is discussed in the section on subsidence (3.2); it is not anticipated to be an issue of significance. However, should faulting occur, it could affect the integrity of oil or brine pipelines and possibly some surface facilities. 
Based largely on studies for the South Texas Nuclear Plant located near Bay City, 40 miles west of Bryan Mound, the maximum credible earthquake was assigned a Modified Mercalli intensity of VI, which translates to an acceleration of approximately $0.07 \mathrm{~g}$ at the site. This value is very similar to peak accelerations experienced near the epicenter during the 19 Oct 30 Donaldsonville, LA, event, epicentered $40 \mathrm{mi}$ southest of the Bayou Choctaw site, and which effectively has become the design basis earthquake for the Gulf Coast. The basic conclusions reached in the 1980 Bryan Mound study remain valid; only minor refinements are offered in Appendix B to update the understanding of seismic risk. The additional possibility, although remote, of induced seismicity from injection wells is also addressed.

\subsection{Expansion Cavern Possibilities}

Currently there is no SPR requirement to identify additional cavern locations, but future situations conceivably could necessitate that. Such an eventuality is briefly addressed, not withstanding the surface problems that would have to be addressed such as low elevation and standing water in Blue and Mud Lakes.

The principal limiting criteria for additional cavern space is the amount of available salt beyond existing caverns and around the dome periphery. This determination invokes major uncertainty because of the small number of wells and other data. The $300 \mathrm{ft}$ buffer distance between the outside cavern wall and dome edge is a minimum; $500 \mathrm{ft}$ is thought to be better, as salt conditions usually are less pure and physical properties are often deteriorating as the edge is approached. A summary of the external dome features is shown in Table 6.

There may be space for one or two 10 MMB caverns south of Cavern 114 and/or Cavern 109 along the southern perimeter of the dome (locations \#217, \#218; (Figure 16). Location $\# 217$ is in Mud Lake and would require protective diking, similar to Cavern 113. A small overhang occurs on the southern side of the dome and an exploratory borehole might be required to validate this location. The present surface elevation of $<5$ $\mathrm{ft}$ is a siting factor having potential operational ramifications, but probably of no more concern than other low-lying parts of the site. Regardless of location on the dome, the SPR site needs hurricane protection. 


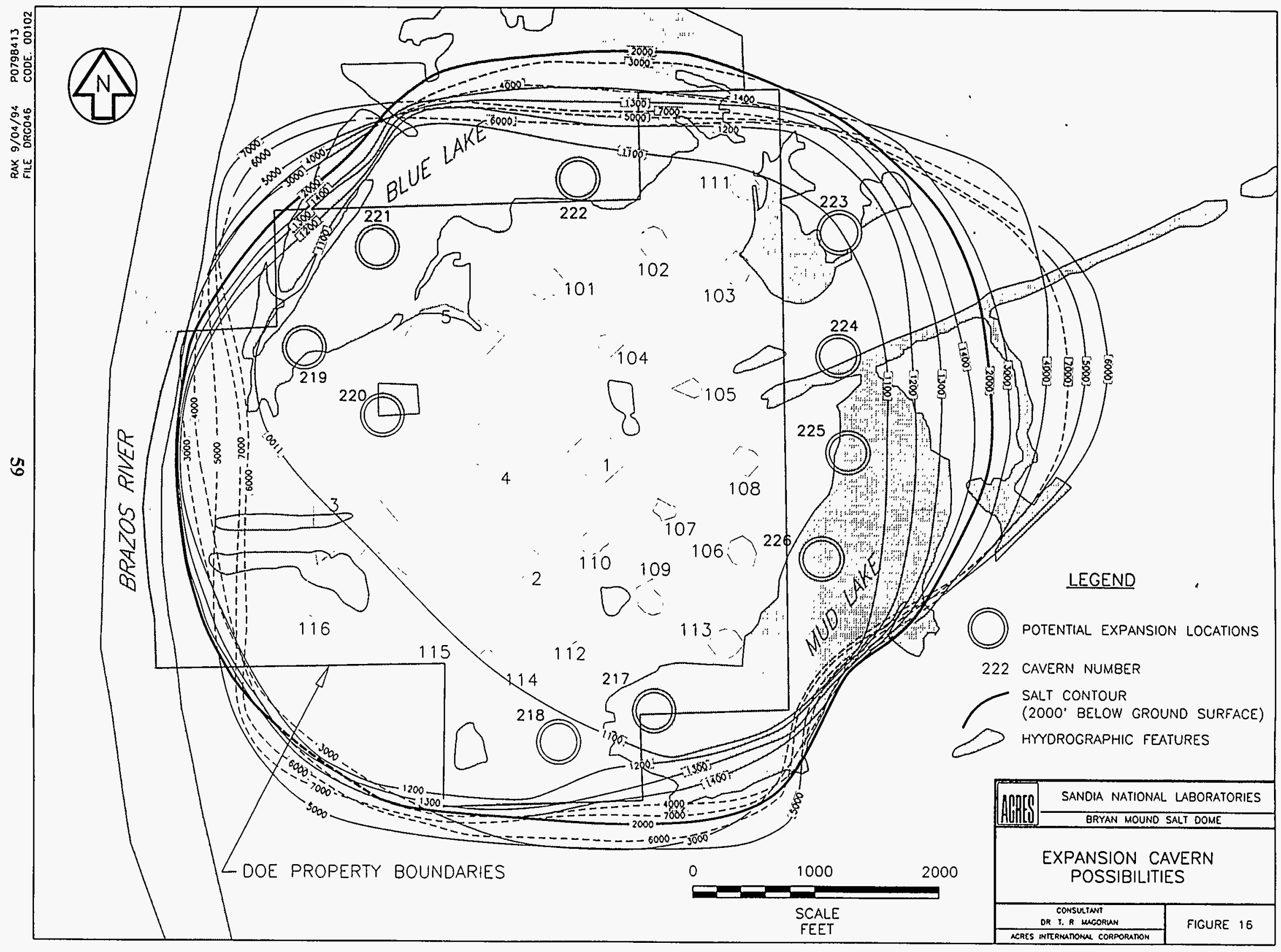




\section{Table 6 Additional Storage Possibilities (from Interpreted Geologic Sections)}

$\underline{\text { Flank }}$

SE

NW

$\mathrm{N}$

SW

$\mathrm{NE} / \mathrm{E}$

$\mathrm{S}$

W
Potential

OK

Questionable*

Questionable*

OK

$\mathrm{OK}$

OK

OK

\section{Remarks}

Sediment convergence shows vertical salt wall

Assumed || to SE geometry; deep overhang from 1949 seismic survey unlikely ${ }^{+}$

No well control, even from convergence extrapolation

Well defined shallow overhang

Bulge, shale sheath; assume overhang below $5000 \mathrm{ft}$

Probable shallow overhang

Wide shale sheath below $\mathrm{AB}$ unconformity

${ }^{*}$ Principal discrepancy: Modern seismic profiling required. ${ }^{+}$The wide shale sheath found since the previous characterization makes this location relatively safe.

A second $10 \mathrm{MMB}$ cavern location (\#223) has been suggested on the east side of the dome, northeast of Cavern 103 and off of DOE property. This location is also $<5 \mathrm{ft}$ above sea level. A confirmatory borehole would establish the dome configuration and validate the suitability of this location. Locations south of here and east of the DOE property are also possibilities for two or three additional caverns.

Locations on the west and northwest perimeter of the dome (\#s 219, 221, 222) might be considered but have more uncertainty and exploratory boreholes or additional geophysics are needed to validate the dome geometry. That is because the seismic data on which these overhangs were interpreted are unreliable, probably having been exaggerated in the interest of economic promotion. The low-lying elevation must also be considered; all three are in or very close to Blue Lake and reclamation/diking would be necessary. Additional property acquisition would be required for locations \#222, 223 , and those south of 223 (224-226).

Cavern 3, plugged and abandoned, is pancake-shaped and considerably more shallow than DOE Phase III caverns; room for a deeper cavern (\#220) under Cavern 3 is a possibility, but integrity evaluation would be required. A similar location west and under Cavern 3 is also possible but requires evaluation.

Assuming the above concerns can be reconciled, Bryan Mound most likely has 
under Cavern 3 is also possible but requires evaluation.

Assuming the above concerns can be reconciled, Bryan Mound most likely has space for at least three additional $10 \mathrm{MMB}$ caverns, and very probably three others for a total of $60 \mathrm{MMB}$, and possibly more, but only with confirmatory exploration. This assumes that mitigative work to overcome the low elevations and water-based sites could be accomplished readily.

\section{SUMMARY OF SIGNIFICANT FINDINGS AFFECTING SPR}

Refinements to the original (1980) geological characterization have been made; those topics most relevant to operations are identified and summarized as follows:

- Salt stock shape is quite cylindrical, with steep overhangs on the north, east, and south sides, and a localized bulge (nose) on the east. The northwest overhang identified in the 1980 report is probably not present, as interpreted from the gravity contours and limited well control. The new interpretation, although requiring verification, would allow for as many as six new caverns of 10 million barrel size. Some of these locations underlie Blue and Mud Lakes on the site periphery.
- Structural features include radial faults external to the dome and two probable anomalous zones transecting the salt stock and dividing it into four separate lobes or spines. These structural features probably control permeability zones within the salt and may account for the differential release of gas from salt into the oil, but this has not been definitively established

- Presumed salt falls have been a persistent, recurring problem in ten separate caverns with some 37 incidents occurring over a ten-year period. While the caverns involved are clustered together in two areas and suggest some possible 
excessive intrusion in the future. A satisfactory geological explanation for this differential expression is not evident.

- Subsidence is the lowest of all the SPR sites, even though the volume is large, comparable with West Hackberry, which has a subsidence rate some six or seven times greater. The explanation appears to lie in slower laboratory creep for Bryan Mound salt and in slightly deeper caverns at West Hackberry, which leads to increased cavern creep closure.

- Flooding risks are virtually unchanged with respect to the SPR site, however minor revisions have been made in the most recent FEMA analyses regarding the surrounding region. 100-year flood elevations from hurricane surge can be expected to temporarily flood low-lying elevations under 10.0-11.0 feet. Shorelines at Bryan Beach are considered stable and will not recede appreciably in coming decades.

- Bryan Mound is in a seismically quiescent portion of the Gulf Coast. Although minor earthquakes are expected to occur periodically, such as the Oct 83 West Hackberry temblor $(M=3.8)$, the maximum intensity is estimated to be very low (Modified Mercalli $=$ VI), and virtually no damage of consequence will occur.

- This characterization update should be reevaluated periodically for currency and reaccomplished in not more than ten years. 


\section{ACKNOWLEDGMENTS}

This effort to reevaluate the Bryan Mound geological characterization has been made easier by the splendid cooperation and assistance from many colleagues: Stu Thompson at Acres International Corporation, Bob Thoms of AGM Inc., Ken Mills of the DynMcDermott Petroleum Operations Company, and Steve Bauer, Marianne Walck, and
Brian Ehgartner of Sandia National Laboratories, who reviewed all or portions of the report and made many suggestions for improvement. We also thank Sam Wallace and Fran Grosshans at Sandia for the many hours of help in which they assisted in the myriad of small tasks necessary to produce such a report.

\section{REFERENCES}

Barbic, D. (1993) Personal Communication, U. S. Geological Survey, Houston, TX.

Bodine, B. R. (1969) Hurricane Surge Frequency Estimated for the Gulf Coast of Texas, U. S. Army Corps of Engineers, Coastal Engr, Res. Ctr. Tech. Mem.26, 32 pp.

BPS (Boeing Petroleum Services, Inc.) (1990) DOE/SPR Acquired Cavern History. Pub. D506-02634-09, Boeing Petroleum Services, New Orleans.

Davis, S. D., W. D. Pennington, and S. M. Carlson (1989) A Compendium of Earthquake Activity in Texas. Texas Bur. Econ. Geol. Circular 89-3. Austin, TX, 27 pp.

FEMA (Federal Emergency Management Agency) Flood Insurance Rate Map, Brazoria County, TX and Incorporated Areas, Map No. 48039CO770J, Revised 17 Nov 93.

Gabrysch, R. K. (1982) Ground-Water Withdrawals and Land-Surface Subsidence in the Houston-Galveston Region, Texas, 1906-80. U. S. Geol. Surv. Open-File Report 82-571, Austin, TX.

Hinkebein, T. E. (1994) Gas Intrusion Into SPR Caverns. Sandia National Laboratories Rept. SAND94-0023, Albuquerque, $\mathrm{NM}$, (in prep.).

Hogan, R. G., et al. (1980) Strategic Petroleum Reserve (SPR) Geological Site Characterization Report: Bryan Mound Salt Dome. Sandia National Laboratories Report SAND80-7111, Albuquerque, NM. 
Holzer, T. L, and R. K. Gabrysch (1987) Effect of Water-Level Recoveries on Fault Creep, Houston, Texas. Ground Water, 25 , No. 4 , p. $392-397$.

Hoffman, E. L., and B. L Ehgartner (1993) Effects of the Number of Caverns on Storage Loss and Subsidence of Oil-Filled Caverns. 34th U. S. National Rock Mechanics Symposium, Madison, WI, June.

Magorian, T. R. and J. T. Neal (1988) Strategic Petroleum Reserve (SPR) Additional Geological Site Characterization, Big Hill Salt Dome, Texas. Sandia National Laboratories Report SAND88-2267, Albuquerque, NM, 73 pp.

Mills, K. E. (1994) DynMcDermott Petroleum Operations Company, New Orleans: Informal communication.

Morton, R. A, and M. J. Pieper (1975) Shoreline Changes in the Vicinity of the Brazos River Delta (San Luis Pass to Brown Cut), an Analysis of Historical Changes of the Texas Gulf Shoreline. Texas Bur. Econ. Geol., Geol. Circ. 75-4, Austin.

McHenry, J. M. (1992) Annual Subsidence Report - All Sites, FY 92. Boeing Petroleum Services, New Orleans, LA.

McGowen, J. H, L. F. Brown, Jr., T. J. Evans, W. L. Fisher, and C. G. Groat (1976) Environmental Geologic Atlas of the Texas Coastal Zone - Bay City-Freeport Area. TX Bureau Econ. Geol., Austin, 98 pp.

Mills, K E. (1994) Personal Communication, DynMcDermott Petroleum Operations Company, New Orleans, LA.

Neal, J. T. (1991) Prediction of Subsidence Resulting from Creep Closure of Solution Mined Caverns in Salt Domes. In Land Subsidence, Proc. 4th Intl. Symp. on Land Subsidence, May, 1991. IASH Publ. no. 200.

Neal, J. T., T. R. Magorian, R. L. Thoms, W. J. Autin, et al. (1993) Anomalous Zones in Gulf Coast Salt Domes with Special Reference to Big Hill, TX, and Weeks Island, LA. Sandia National Laboratories Rept. SAND92-2283, 65 pp., Albuquerque, $\mathrm{NM}$.

Oil and Gas Journal (1993) DOE to Degassify 200 Million Barrels of SPR Crude, 3 May 1993, P. 130

Oil and Gas Journal (1994) Gas Encroachment Cuts SPR Drawdown Rate, 18 April 94, P. 27.

Paine, J. G., and R. A. Morton (1989) Shoreline and Vegetation-line Movement, Texas Gulf Coast, 1974-1982. Texas Bur. of Econ. Geol., Geol. Circular 89-1, Austin.

POSSI (1983) Bryan Mound Cavern 4 Well Failure Report; Response to Technical Direction 45. Doc. 159-83-0176, 30 Mar 83. Preece, D. S. and Foley, J. T. (1984) Long-Term Performance Prdictions for Strategic Petroleum Reserve (SPR) Salt Caverns. Sandia National Laboratories Report SAND83-2343, 81 pp., Albuquerque, NM.

Shipp, W. (1993) Personal Communication, Superintendent of Water Dept., City of Freeport, TX.

Tanner, S. (1991) Informal Communication. Galveston District, U. S. Army Corps of Engineers.

Verbeek, E. R. (1979) Surface Faults in the Gulf Coastal Plain Between Victoria and Beaumont, Texas. Tectonophysics, $\underline{52}$, p. $373-375$.

Wawersik. W. R., and D H. Zeuch (1984) Creep and Creep Modeling of Three Domal Salts -A Comprehensive Update. Sandia National Laboratories Report SAND84-0568, Albuquerque, NM, 93 pp. 


\title{
APPENDICES
}

\author{
A Regional Geology \\ B Seismicity and Faulting Potential \\ C Bryan Mound Well Data
}

D Selected Core and Thin Section Photographs 


\section{APPENDIX A}

\section{Bryan Mound Regional Geologic History}




\section{APPENDIX A}

\section{Bryan Mound Regional Geologic History}

\section{Introduction}

This overview is intended for readers that desire general information, and for those having limited background in the geosciences. It is not detailed, and is uneven in presentation by design. The reader who desires more complete information should refer to the original characterization report [Hogan et al., main report], or to more recent general references on Gulf Coast geology and tectonics [Worrall and Snelson, 1989].

\section{Paleozoic Era (570-245 my)}

The single protocontinent called Pangaea ("all lands") that drifted together at the end of the Paleozoic, resulted in a huge mountain mass, probably somewhat like the Himalayas today. It lay to the north (relative to today), including the center of North America, and is thought to have been glaciated periodically, tying up much ocean water in icefields.

No rocks of Paleozoic age are expected to underlie the site, as the nearest known exposures are of Bend turbidites on the Colorado River above Austin, TX, some $190 \mathrm{mi}$ to the northwest. Metamorphosed Paleozoic schist extends eastward from Bell County, TX, just north of the AngelinaCaldwell flexure, which marks the south end of the Sabine Uplift separating the East Texas Salt Dome Basin from the North Louisiana Salt Dome Basin. Although little of this schist has been dated in Texas, it is equivalent to the Wissahickon schist of the East Coast Piedmont, known to be primarily of Cambro-Ordovician age, Southeast of the ridge, Mesozoic rocks may have been deposited on oceanic basalt crust of the edge of the continental shelf of the time.

\section{Mesozoic Era (245-66 my)}

The immense mass of the Paleozoic mountains led to the deformation and breakup of Pangaea during Jurassic time, initiating the Gulf of Mexico Basin and in the process forming volcanic rifts, similar to the African rift valleys and Red Sea today. The Gulf Coast Geosyncline, or major depositional basin, was one of a string of rift basins created by the opening of the Atlantic during the breakup of Pangaea. This process separated North America from South America and Africa, forming the Gulf of Mexico and the central Atlantic concurrently. This drifting apart of the present continents continues at a more or less steady rate, as it has since the end of the Paleozoic.

Triassic Period: Any basalt which is found under the site could be as old as Triassic and associated with the redbeds found in these deposits in both the East Coast and the Western United States. These are the oldest deposits of the Mid-Atlantic rift system which has carried the North American continental plate away from Africa and Europe and forms the active volcanoes of Iceland and the Azores. Triassic Eagle Mills basalts 
and redbeds are known in the subsurface of East Texas and North Louisiana.

Jurassic Period: The desert redbeds of early Jurassic age overlying the Triassic volcanics are called Norphlet in the Gulf Coast. The rift-valley depositional basin of the Jurassic Louann salt and evaporites, which underlies the Norphlet, was similar to some extension evaporite basins in East Africa and the Red Sea today. For the East Texas Province, Jackson and Seni [1984] estimated the original thickness of the Louann salt to be 5,000 to $7000 \mathrm{ft}$, although only $3000 \mathrm{ft}$ has been drilled. Two separate evaporite basins rifted apart: a northern region consisting of the coastal plain and off-shore regions Texas, Mexico, Louisiana, Mississippi, Florida and southern Arkansas; and a southern belt along the west and northwest flank of the Yucatan Peninsula. The present-day thickness and distribution of the "mother salt" is different than its original position as tilting of both basins has caused the migration of salt structures at depth, according to modern geological concepts.

Major changes in sea level and global temperatures provided widespread conditions for organic growth and preservation. The sealing anhydrite overlying the Triassic volcanics is called Buckner. The overlying oolite and dolomite is known as Smackover, the Gulf Coast correlative of the Arab limestone pay of the Persian Gulf, the most oilproductive horizon in the world. The remainder of the overlying Jurassic consists of a thick sequence of Cotton Valley limestone and Bossier bituminous shale. Although the salt in the Bryan Mound dome is of Jurassic age, it may have been deposited to the north or northwest, so that only oceanic basalts of this age or even younger were ever deposited here. None of these Jurassic rocks other than the salt have yet been drilled at Bryan Mound.

The salt from which the Bryan Mound salt dome formed is probably not in its original depositional position. It may have migrated southward and upward as a sill through the sediments described above or outside, seaward of the thick sediment wedge at a depth of two or three to six or seven miles. This sill is believed to be exposed at the toe of the sediment pile on the floor of the Sigsbee Deep, the oceanic trough in the Gulf of Mexico.

Continental rafting and seafloor spreading have revolutionized the concept of the origin of basins like the Gulf Coast Geosyncline; this current concept of deep horizontal salt migration and intrusion discussed here is one of the most innovative and important ideas today affecting hydrocarbon and salt development.

Cretaceous Period: The sequence of rocks found updip (inland of Bryan Mound) consists of the lower or Comanche age Hosston clastics and limes, Sligo oolitic limestone, Pine Island shale, the James lime reef covered by Ferry Lake anhydrite and Glen Rose limestone, forming a thick reef like Florida and the Bahamas. Bryan Mound is probably seaward of the reef front. This is all overlain unconformably by the almost-global upper Cretaceous Chalk section: called Austin, Taylor, and Navarro in Texas.

The chalk probably underlies the site in normal position, and may underlie the salt sill and thereby contain producible oil and gas -- 
which DOE has acquired along with the salt. But even these rocks have never been penetrated along the coast

\section{Cenozoic Era (66-2 my)}

Tertiary Period: The downdip surface section of the Gulf Coast proper in Louisiana and Texas is a thick pile of Tertiary sands and shales, correlative with the carbonates of Florida and the Bahamas. All of these deposits face the active east-west tectonic zone running from the Mexican volcanoes through the greater Antilles from Cuba to the Virgin Islands.

Paleocene Epoch: The Tertiary sequence of the Gulf Coast starts with Midway shale, a normal marine mud deposit washed west from the Mississippi (or equivalent) Delta . This sedimentation preceded the Laramide orogeny, the plate collision that created the Rocky Mountains and flooded the Gulf with coarse clastic debris. Based on the reconstruction of the regional geology, the ocean floor here was certainly solidified in place here by the end of the Cretaceous, so that it seems reasonably certain that a full, marine Tertiary section underlies the site.

Eocene Epoch: These are the oldest sediments deposited in the Gulf Coast delta sequence. As sediments accumulate on the north shore of the Gulf of Mexico, the older sediments are depressed and compacted, increasing their dip toward the Gulf. Ultimately, a thick sedimentary section accumulated on the edge of the continent, referred to as the Gulf Coast Geosyncline. This simple regional picture is complicated by the instability of the underlying salt which formed more than 550 domes, all arising indirectly from the "mother salt", the Louann, found at depths of $30,000-40,000 \mathrm{ft}$ in the Bryan Mound area.

Wilcox deltaic deposits as much as two miles thick, including coal measures which have been penetrated updip from the coast in Jefferson County, Texas, to the Rio Grande, represent the Laramide deposits. These are overlain by downdip Yegua shales which in turn are overlain by Jackson shale, part of the shallowest mature bituminous shale sequence of the Gulf Coast. The upper part of the bituminous sequence is the Vicksburg limy shale, of lower Oligocene age penetrated in the shale sheath in many domes However, none of these deposits have been penetrated yet at Bryan Mound and it appears that the Wilcox delta may not extend as far down dip as the coast at Bryan Mound.

Oligocene Epoch: The deep tests drilled by Humble (FSC \#6, SW flank) and Houston Oil and Minerals (FSC \#1, NW flank) appear to have been targeted at Frio sands, which are an important production zone at Peach Point, $8 \mathrm{mi}$ northwest of the dome and at other salt domes such as Stratton Ridge, $7 \mathrm{mi}$ northeast of Bryan Mound. The Frio formation is a thick marine sequence of sediments increasing in thickness from shoreline sands near the outcrop area in Frio County, TX, to deeper-water deposits of predominant geopressured shales and lesser turbidite sands near Bryan Mound. Wells drilled on the northwest flank of the dome were presumably targeted at the distal edge of turbidite sands such as those which produced at Peach Point. However, virtually 
no sand was found. Table 1 lists principal stratigraphic horizons important to the geological interpretation.

The Anahuac Formation of Upper Oligocene is represented in thick shale units in all deeper wells and sheaths the dome; it is more than ten thousand feet thick in some wells in the vicinity. It contains at least two paleontological markers, from Discorbis and Heterostegina through Marginulina howei. At Damon Mound, some 35 mi north, and Stratton Ridge, seven miles northeast, the Heterostegina zone consists of thick coral reefs (atolls), but at Bryan Mound the Anahuac is a relatively continuous deep-water

\section{Table 1 Bryan Mound Stratigraphic Correlation Chart}

$\underline{\text { Unit }}$

\section{Holocene}

Pleistocene

Beaumont

Lissie

Montgomery

Bentley

Lafayette

Pliocene

Miocene

Goliad
Symbol

MO

LS (lower Lissie)

PL

MI
Lithology

alluvium

marine clay

sand

mud

sand and gravel

sand and mud

$$
\begin{aligned}
& \text { sand (Bigenerina A) } \\
& \text { shale } \\
& \text { sand (Bigenerina B) } \\
& \text { shale } \\
& \text { sand (Textularia L) } \\
& \text { shale } \\
& \text { sand (Bigenerina 2) } \\
& \text { shale }
\end{aligned}
$$

Bigenerina humblei - - - UNCONFORMITY

sand (Cristellaria $\mathrm{I}$ )

shale

sand (Cibicides opima)

Lagarto

AB
RL

shale

Oakville

deltaic sands

\section{Oligocene}

Anahuac

Frio
DR

F shale

geopressured shale* and turbidite sand

* $\mathbf{P}$ on cross-sections (Figures 8-11) indicates geopressure, marked by reduced resistivity 
shale, containing relatively more volcanic ash than the overlying Miocene shales. The Anahuac at Bryan Mound is more than $11,000 \mathrm{ft}$ thick and overpressured, separating any possible deeper Frio pays from the overlying Miocene sand pile.

Three dramatic angular unconformities on this dome occur at the top of the Anahuac (basal Goliad, Lagarto, A \& B, and Pliocene). The underlying Frio sands were uplifted and eroded by salt movement before Miocene deposition. This basal Miocene unconformity is one of three in the geologic history of the dome. The erosion occurred in the interval in which Heterostegina coral reefs developed to the east, including the atoll surrounding Bayou Choctaw, Stratton Ridge, Damon Mound, and many other domes. The alluvial Miocene sands lie across dipping and eroded Oligocene Oligocene Frio sands at angles of 65 degrees and probably higher from the horizontal. Here the angular unconformity is underlain by geopressured shale sheath, on which the normally-pressured Miocene sands lie in angular unconformity.

Another possible unconformity occurred in the middle of the Miocene at the top of the Lagarto Shale, under the Goliad sands (as now correlated with the updip outcrop). A final unconformity occurs at the top of the Miocene. Underlying Goliad beds may be very steep on the northwest side of the dome.

The top of the Anahuac shale is mapped (Figure 7, main body of report) to show the depth of an additional impermeable sheath around the dome, which can serve to provide a barrier in the unlikely event that a cavern were inadvertently leached through salt. This sheath, consisting of light volcanic-ash-rich mud forms a mobile sheath at geopressure around most of the salt stock below $3000 \mathrm{ft}$. This horizon is also best known from oil wells drilled on the flanks, so that these maps best reflect the control used in the subsurface study.

The linear down-to-the-coast growth faults (listric normal faults) of the middle Texas coast coalesce along the Vicksburg Flexure (shown as a bold line on the regional map), which approximately bounds the geopressured Anahuac shale, as well as being the updip margin of Vicksburg production. To the east, it intersects the edge of the Hackberry Embayment which include Big Hill and West Hackberry SPR sites (Figure A-1).

Miocene Epoch: Recent work by the Texas Bureau of Economic Geology has clarified the divisions of the Miocene in Texas between the outcrop and the subsurface [Galloway, 1986]. The lower Miocene deltaic sand sequence, originally used for brine disposal at Bryan Mound, is now correlated with the Oakville sands of the Live Oak County outcrop. The Middle Miocene shale of Amphistegina B age is now correlated with the Lagarto of the South Texas outcrop. The thick upper Miocene sandy sequence is now called Goliad. These sediments, which are productive of gas immediately offshore and of the small quantity of oil found on the south side overhang of the Bryan Mound salt stock, actually flank the storage in the salt above 3000 feet.

The outer edge of the shelf grew southward by several stages of deltaic progradation in lower Miocene time, so that the 


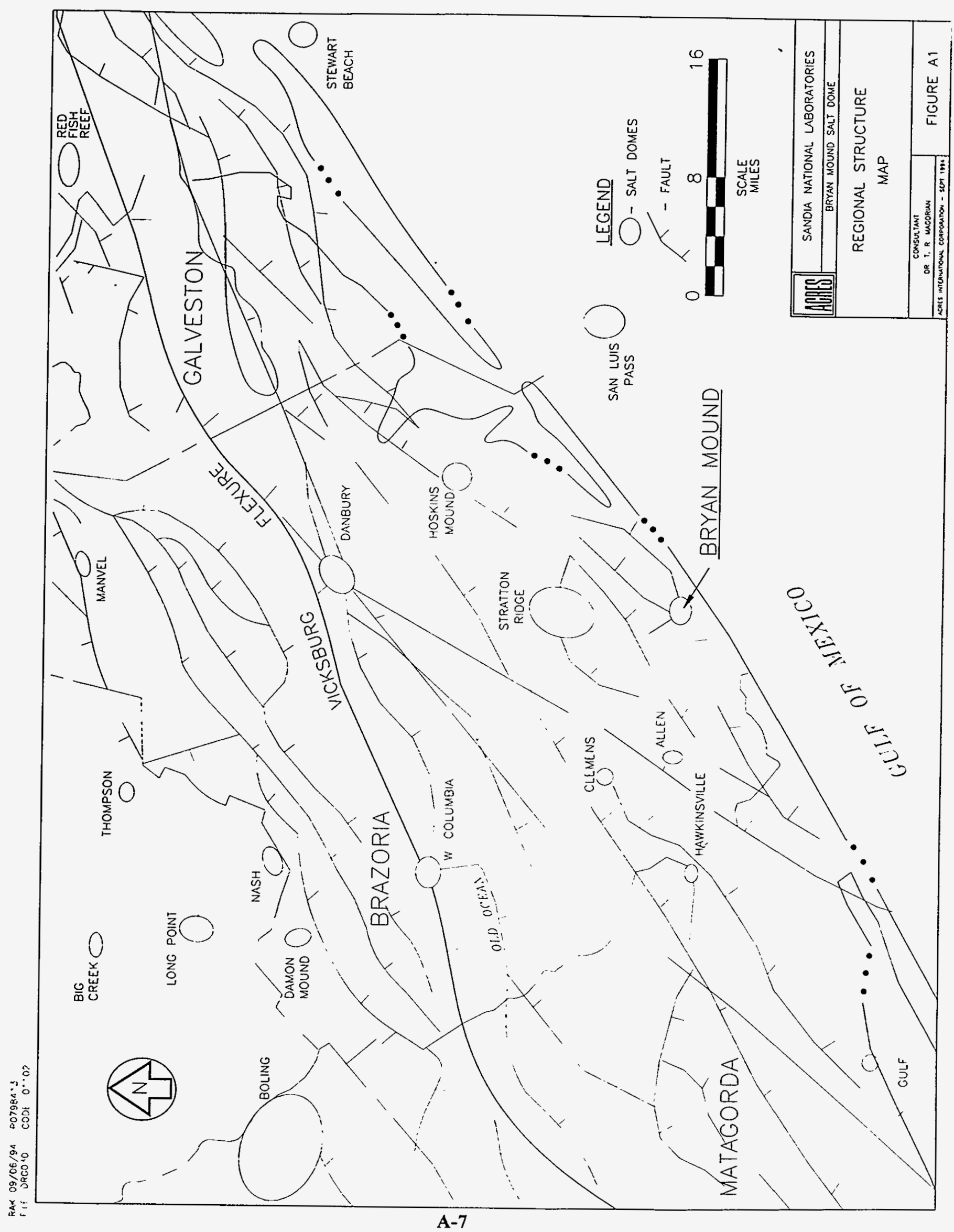


Anahuac shale is overlain by a clastic wedge, ranging from less than $2000 \mathrm{ft}$ thick on the coastal plain to more than $10,000 \mathrm{ft}$ offshore. This thick sediment pile being dumped off the south edge of the North American continent at least since the Miocene is responsible for deforming the underlying Jurassic salt into ridges and domes. The intense loading by Miocene sediments activated many of growth faults associated with the shelf edge. Dips in these sands are limited to 30 degrees, even against the near-vertical salt face, except possibly at the northwest corner of the dome.

The base of the sand pile is paleontologically marked by the disappearance of Discorbis "restricted," the last far-offshore deposit in the stratigraphic sequence. The rest of the lower Miocene is represented by thick alluvial sands, the Oakville Formation, becoming more shaly with decreasing depth. The lower part has marine shale breaks including Siphonina davisi, correlated on some logs, and the Amphistegina zone unconformity. The predominantly sandy lower portions are suitable as brine disposal zones.

The middle Miocene is represented by the last marine shale breaks, particularly those containing the Amphistegina $\mathrm{B}$ fauna with volcanic ash from the Mexican orogeny. This is the shallowest paleontologic data point available around the dome, the upper Miocene being less marine. Table 1, the stratigraphic correlation chart, shows younger zones by their standard paleontological name, even though the marker microfossil is rare in these mostly non-marine sediments at Bryan Mound. These units have been correlated around the dome but have no other recognized name.
The middle Miocene is represented by the Lagarto shale, which also contains a few thin, relatively variable sands, Cibicicdes optima to the Bigenerina howei unconformity.

The alluvial section continues through the upper Miocene and into the PlioPleistocene and is now called the Goliad Formation in Texas, representing ancestral riverine deposits of present rivers. The basal unit is gravelly, resting unconformably on the marine Miocene. The Goliad consists of a series of "dirty" point-bar gravels, each some $100 \mathrm{ft}$ thick, approximately the same as the natural flood channel of the Brazos River. The Goliad has the most extensive permeability (although not high) of any fully-saline sand and gravel on the Brazos-Colorado Delta; this is significant because of its potential for brine injection wells at the SPR site. These low permeability bars are overlain by cleaner reworked sands, silts and muds, some reasonably permeable. This unconformity below the gravel is eroded deeply into the middle Miocene close to the dome, indicating the dome had extensive surface expression during this onshore alluvial deposition.

Pliocene Epoch: These sediments are mostly back-bay clay shales with a few deltaic sand sequences, with brine disposal potential, and a few thin limy zones. (See Section 2.1 , main body of report.)

\section{Quaternary Period $(<2 \mathrm{my})$}

Pleistocene Epoch: The basal preglacial unconsolidated Lafayette gravels (also called Willis, Williana, and Citronelle locally) erode into the underlying Pliocene; it is thin and shallow at Bryan Mound. The 
overlying sediments are fresh-water bearing and were deposited during and after each of the glaciations of the continent to the north, when sea level was as much as $460 \mathrm{ft}$ lower than today, and in the following interglacial stages as the sea returned to near its present level. Thus the basal sand of each sedimentary sequence, outwash brought down to the Gulf, is correlated with the glacial stage and the overlying mud with the following interglacial. Some or all of the glacial stage is actually represented by the basal unconformity below each channel sand [Ref. A-2].

Nebraskan Stage: The oldest glacial sequence is Nebraskan, found at the top of or just above the Lafayette (Willis) gravel. The overlying Aftonian mud contains a distinctive volcanic ash marker like those of the middle Miocene, which has been tied to the volcanic or orogenic theory of glaciation.

Kansan Stage: The Kansan, here mostly marine, is the Lenticulina sand, on the flanks of the dome. The Yarmouthian Angulogenerina clay, which represents the long interglacial interval in the middle of the Pleistocene, is called Bentley (or lower Lissie) and is found at $500 \mathrm{ft}$ over the top of the dome. It contains the uppermost glauconite marker in the sedimentary section, indicative along with the microfauna, of the most recent open marine sedimentation.

Illinoian Stage: Montgomery (or Upper Lissie) Trimosina sands, at $300 \mathrm{ft}$ over the top of the dome, were deposited during the following glaciation. Sangamon clay was deposited during the following interglacial interval.

Wisconsin Stage: The Beaumont outwash sands of which the basal [Alton], at a depth of $200 \mathrm{ft}$ on top of the dome and 400 $\mathrm{ft}$ on the flanks, is the thickest and most massive, having been correlated over almost every onshore salt dome. At the surface to the northwest, they make up the plain which runs from Beaumont through Wharton to the Rio Grande.

The sands were formed at the lower sea level which occurring when the continental icecap extended to the Ohio and Missouri Rivers. The main sediment sources for the Texas Gulf Coast is the Brazos-Colorado Delta. Most of the sands are alluvial point bars with basal gravels, along with beach sand where the delta front is washed away by hurricanes.. Away from the structural influence of the dome, these sands dip toward the Gulf at the rate of $30 \mathrm{ft}$ per mile.

These unconsolidated sediments are found across the top of the dome, uplifted but not fully breached by the salt intrusion and its overlying residual caprock. The active faults inherent in the caprock extend upward as the salt continues to intrude, deforming these overlying sediments, all the way to the surface.

Holocene Stage: The Pleistocene sands around the dome are overlain off the dome by Beaumont marine clay and mud deposited in the last $5000 \mathrm{yrs}$, during which time sea level rose some $450 \mathrm{ft}$ as the earth's continental icecaps melted, leaving only the ice cover in Greenland and Antarctica. This clay was deposited in the marsh as a soft, highly-organic black gumbo. It includes peat and algal sapropels or greasy layers formed by nutrient blooms in the bays. Water content in these unconsolidated sediments is still as high as $70 \%$. This clay is the seal for the oil accumulation in the caprock at Spindletop in Beaumont, which produced a billion barrels of black oil. Along with these Holocene 
clays, peats and algal sapropels are included in minor river silts and beach sands; they dip toward the Gulf at about 10 feet per mile.

At Bryan Mound, there are a few thin beach sands formed on the dune ridges. The white beach sands are very fine-grained and well-sorted. This beach-ridge complex is a fan with intervening muds, gradually subsiding into the marine clay. The sands shift dramatically during hurricanes, when waves break on the south flank sea cliff of the storage site.

The active shallow faults originating in the caprock or salt shear zones have only displaced the Holocene sediments a few feet. They do not pose any apparent risk to the storage caverns by themselves, but subsidence along them could conceivably damage surface facilities and well casings, as has occurred at other domes used for storage of LPG products, e. g., Stratton Ridge, TX.

\section{References to Appendix A}

Bernard, H.A. and R. J. Leblane (1965) Resume of the Quaternary Geology of the Northwestern Gulf of Mexico Province. In The Quaternary of the United States; Princeton Univ. Press, Princeton, NJ, p. 137-186.

Galloway, W. E. (1986) Depositional and Structural Framework of the Distal Frio Formation, Texas Coastal Zone and Shelf: Texas Bureau of Economic Geology Circular 86-6, Austin, TX, 16 pp.

Ginn, R. (1991) Personal communication, and failure report of Oxy Chem. Inc., Railroad Commission of Texas, Austin, TX.

Jackson, M. P. A., and S. J. Seni (1984) Suitability of Salt Domes in the East Texas Basin for Nuclear Waste Isolation. Univ. Texas at Austin Bur. Econ. Geol. Geological Circular 84-1, 128 pp.

Jackson, M. P. A. and B. C. Vendeville (1994) Regional Extension as a Geologic Trigger for Diapirism. Geol. Soc. Amer. Bull. , v. 106, p. $57-73$.

Worrall, D. M. and S. Snelson (1989) Evolution of the Northern Gulf of Mexico, with Emphasis on Cenozoic Growth Faulting and the Role of Salt. Chapt. 7, in The Geology of North America - An Overview, Geol. Soc. Amer., Boulder, CO, p. 97-138. 


\section{APPENDIX B}

Earthquake Potential at Bryan Mound SPR Site

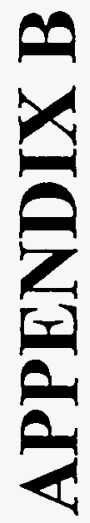

B-1, 2 


\section{APPENDIX B}

\section{EARTHQUAKE POTENTIAL AT BRYAN MOUND SPR SITE}

\section{$\underline{\text { Natural Seismicity }}$}

Bryan Mound is one of the least seismic areas of the Gulf Coast, the least seismic region in the United States. Situated on a stable portion of the North American plate, well away from the edge of the continental shelf, the minor basement seismicity felt further inland is dampened by the thick pile of unconsolidated sediments, especially the geopressured shales upon which overlying sediments float, and to a certain extent the salt.

The 1980 site characterization report [Hogan et al., 1980] discussed the extremely low seismicity of the Gulf Coast region and concluded that small earthquakes could occur during the life of the Bryan Mound facility. Such events probably would not result in any damage to SPR caverns, either from vibratory motion or ground rupture. Several examples that follow attest to this earthquake-safe environment.

An earthquake of Magnitude 3.8 occurred south of Lake Charles, Louisiana, on 16 Oct 83, with epicenter 17 mi north of the SPR facility at West Hackberry. Even though the felt intensity reached Modified Mercalli V (MM V) near the epicenter, the earthquake was most probably not even felt at the site, as the isoseismal map shows it to be in the MM I zone [Stevenson and Agnew, 1988]. Even near the epicenter, the maximum effects were a few instances of books falling from shelves and several unsubstanti- ated reports of cracked plaster, but generally only rattling of doors and dishes was noted.

The 1983 Lake Charles earthquake is instructive in explaining several aspects of Gulf Coast seismicity, and also in validating the seismic environment discussed in the 1980 site characterization report. This earthquake is representative of the predicted risk for Bryan Mound. Most geophysicists agree that earthquakes capable of producing intensities of MM VI (slightly larger than the Lake Charles earthquake) can occur anywhere along the Gulf Coast. Most likely these events originate in deep basement faults, or in combination with more shallow growth faults. Stevenson and Agnew [1988] proposed such a mechanism for the Lake Charles earthquake, with a focal depth of $14.04 \mathrm{~km}$, possibly on a down-dip extension of the Lake Arthur growth fault system. Thus, deep normal faulting within the crystalline basement may control the configuration of many shallower Gulf Coast growth fault systems.

Nicholson and Wesson [1990] have suggested a possible relationship between this earthquake and injection activities at a nearby waste-disposal well and/or oil and gas operations. Although nothing conclusive has been established, induced seismicity occurs elsewhere from such activities. A low level of seismic activity continued in the Lake Charles region following and presumably in association with the 1983 earthquake, possibly indicating aftershocks [Stevenson, 1985]. Further discussion of induced 
seismicity is included later in this appendix.

The largest historical earthquake (MM VI maximum intensity near epicenter) in the Gulf Coast Province occurred near Donaldsonville, LA, on 19 Oct 30 and effectively approximates the design basis earthquake for the nuclear power industry in southeast Louisiana and south Texas. The Donaldsonville event produced an estimated maximum horizontal acceleration at the surface of $\sim 0.07 \mathrm{~g}$. Such acceleration would result largely from higher frequency body-wave motion and likely would be of short (less than two seconds) duration. This does not present design difficulty even for conventional structures, such as SPR surface facilities, and would be of even less concern at subsurface cavern depths in solid salt within the dome because mine openings experience no damage at localities subject to surface accelerations up to about MM VIII [Pratt et al., 1979]., which is greater than would be expected along the Gulf Coast. However, well casing situated in fault zones could be problematic during fault reactivation associated with earth temblors. Casing rupture is not uncommon in the oil industry, but the failure mode most often seen is in rock formations more competent (brittle) than Gulf Coast sediments.

The nuclear industry has further considered a repeat New Madrid event (181112; Magnitude 8+); peak acceleration that would be experienced at the range of Bryan Mound would be much less than a repeat Donaldsonville event near its epicenter, and most probably not be felt. Also, several earthquakes have occurred with epicenters offshore in the Gulf with magnitudes between 4.5 and 5.0 The largest not associated with a known geologic structure was Magnitude 4.8. The conservative peak horizontal acceleration value of $0.1 \mathrm{~g}$ used by the nuclear power industry in south Louisiana is less than what is required in the design of hurricane-force wind loads, and the $0.1 \mathrm{~g}$ value represents an earthquake with more than a $90 \%$ probability of nonexceedance in 250 yrs [Figure B-1, USGS].

A data search of all historical earthquakes greater than magnitude 2.0 that have occurred within about $400 \mathrm{~km}(-250 \mathrm{mi})$ of Bryan Mound since 1960 was conducted by the National Earthquake Information Center (U. S. Geological Survey) [Table B-1; Figure B-2]. The results confirm the very quiet seismic environment discussed above. The nearest seismic event of note in the past 33 yrs was the 7 Apr 92 surface gas explosion which occured at Brenham salt dome, some $110 \mathrm{mi}$ distant. This event had sufficient energy to be felt (and heard) as far away as Galveston.

The Apr-Aug 64 swarm of earthquakes in East Texas (Table B-1; Figure B-2) occurred on a system of normal faults similar to down-to-the-Gulf growth faults that offset Eocene Claiborne strata. More than 70 earthquakes with magnitudes up to 4.4 were recorded near Hemphill. The anomalous nature of this swarm is shown in the large number of events during a short period, at a locale where no seismicity had been reported prior to April of that year, nor after August. An explanation in the flexure of strata caused by sediment loading in the Gulf of Mexico Basin has been advanced, but the 1964 swarm, as opposed to random seismicity, is unexplained, [Davis et al., 1989]. 


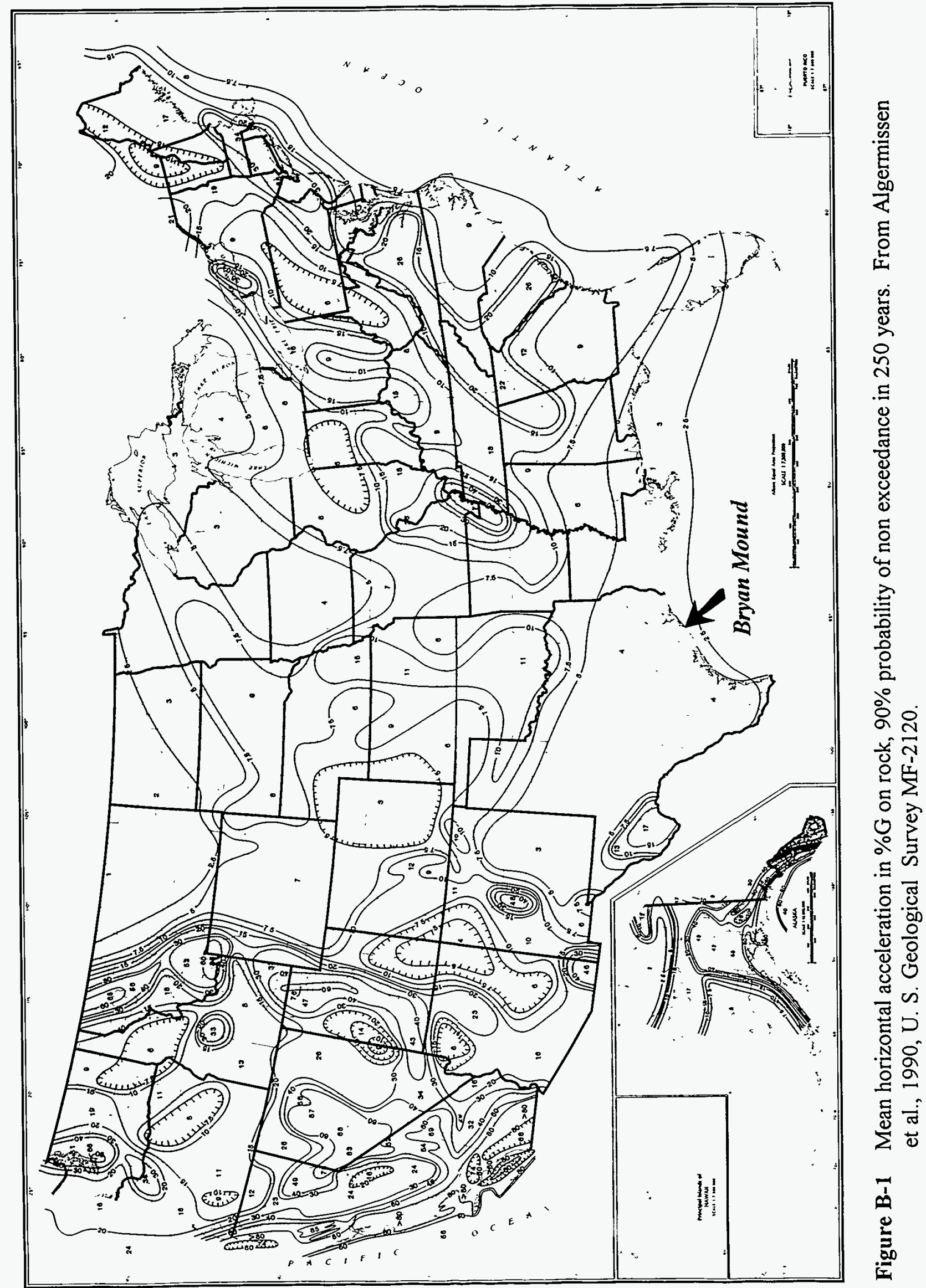


TABLE B-1 SEISMIC EVENTS WITHIN 4OO KM OF BRYAN MOUND; 1960-93, M 2.0-9.9 (excluding redundant reporting stations)

\begin{tabular}{|c|c|c|c|c|c|}
\hline Date & Latitude & Longitude & Depth, km & Magnitude $\left(^{*}\right)$ & Range, Km. \\
\hline $05 \overline{\text { Nov } 63}$ & $27.800 \mathrm{~N}$ & $92.400 \mathrm{~W}$ & 33 & $4.8(\mathrm{mb})$ & 287 \\
\hline $24 \mathrm{Apr} 64$ & 31.500 & 93.800 & 33 & $3.7(\mathrm{mb})$ & 299 \\
\hline $24 \mathrm{Apr} 64$ & 31.600 & 93.800 & 33 & $3.7(\mathrm{mb})$ & 310 \\
\hline $24 \mathrm{Apr} 64$ & 31.478 & 93.787 & 9 & $3.20(\mathrm{Mn})$ & 317 \\
\hline 24 Apr 64 & 31.300 & 93.800 & & $3.00(\mathrm{mb})$ & 299 \\
\hline $24 \mathrm{Apr} 64$ & 31.300 & 93.800 & & $2.60(\mathrm{Mn})$ & 299 \\
\hline $25 \mathrm{Apr} 64$ & 31.300 & 93.800 & & $2.60(\mathrm{Mn})$ & 299 \\
\hline $25 \mathrm{Apr} 64$ & 31.300 & 93.800 & & $2.90(\mathrm{Mn})$ & 299 \\
\hline $25 \mathrm{Apr} 64$ & 31.300 & 93.800 & & $2.90(\mathrm{Mn})$ & 299 \\
\hline $26 \mathrm{Apr} 64$ & 31.300 & 93.800 & & $2.70(\mathrm{Mn})$ & 299 \\
\hline $26 \mathrm{Apr} 64$ & 31.550 & 93.780 & $5^{+}$ & $3.3(\mathrm{mb})$ & 324 \\
\hline $27 \mathrm{Apr} 64$ & 31.300 & 93.800 & & $3.20(\mathrm{mb})$ & 299 \\
\hline $28 \mathrm{Apr} 64$ & 31.500 & 93.800 & & $3.10(\mathrm{mb})$ & 318 \\
\hline $28 \mathrm{Apr} 64$ & 31.500 & 93.800 & 33 & $3.4(\mathrm{mb})$ & 299 \\
\hline $28 \mathrm{Apr} 64$ & 31.200 & 93.900 & 33 & $4.4(\mathrm{mb})$ & 265 \\
\hline 30 Apr 64 & 31.200 & 94.000 & & $3.00(\mathrm{mb})$ & 280 \\
\hline 02 May 64 & 31.300 & 93.800 & & $3.20(\mathrm{mb})$ & 299 \\
\hline 07 May 64 & 31.500 & 93.800 & & $3.20(\mathrm{Mn})$ & 318 \\
\hline 02 Jun 64 & 31.300 & 94.000 & & $4.2(\mathrm{mb})$ & 290 \\
\hline 03 Jun 64 & 31.300 & 94.000 & 30 & $4.2(\mathrm{mb})$ & 290 \\
\hline 03 Jun 64 & 31.000 & 94.000 & & $3.60(\mathrm{mb})$ & 261 \\
\hline 16 Aug 64 & 31.400 & 93.800 & & $3.00(\mathrm{mb})$ & 309 \\
\hline 19 Aug 64 & 31.000 & 93.800 & & $2.70(\mathrm{Mn})$ & 299 \\
\hline $24 \operatorname{Mar} 66$ & 30.000 & 94.000 & & $3.00(\mathrm{mb})$ & 174 \\
\hline 04 Oct 67 & 27.000 & 94.000 & & 3.20 & 252 \\
\hline 03 Feb 70 & 31.000 & 97.000 & & $3.80(\mathrm{mb})$ & 277 \\
\hline $25 \operatorname{Dec} 73$ & 29.000 & 98.300 & & $3.80(\mathrm{mb})$ & 288 \\
\hline 13 Feb 81 & 30.000 & 91.800 & & 3.75 & 362 \\
\hline $18 \mathrm{Feb} 81$ & 28.230 & 91.360 & 10 & 3.00 & 396 \\
\hline 09 Jun 81 & 32.142 & 94.399 & $5^{+}$ & $3.00(\mathrm{Mn})$ & 352 \\
\hline 06 Nov 81 & 32.021 & 95.262 & $5^{+}$ & $3.20(\mathrm{Mn})$ & 335 \\
\hline $28 \mathrm{Mar} 82$ & 29.849 & 98.465 & $5^{+}$ & $3.00(\mathrm{Mn})$ & 348 \\
\hline $23 \mathrm{Jul} 83$ & 28.743 & 98.131 & $5^{+}$ & $3.40(\mathrm{Mn})$ & 306 \\
\hline 16 Oct 83 & 30.243 & 93.393 & $5^{+}$ & $3.40(\mathrm{Mn})$ & 207 \\
\hline 03 Mar 84 & 28.852 & 98.461 & $5^{+}$ & $3.80(\mathrm{Mn})$ & 337 \\
\hline 08 Aug 84 & 29.133 & 98.362 & $5^{+}$ & $3.00(\mathrm{Mn})$ & 327 \\
\hline 20 Jul 91 & 28.908 & 98.042 & $10^{+}$ & $3.60(\mathrm{Mn})$ & 296 \\
\hline 07 Apr 92 & 30.100 & 96.500 & $0^{+}$ & $2.30(\mathrm{Mn})$ & 189 \\
\hline 10 Aug 92 & 29.000 & 98.500 & $5^{+}$ & $2.80(\mathrm{Mn})$ & 340 \\
\hline 09 Арг 93 & 28.809 & 98.178 & $5^{+}$ & $4.30(\mathrm{Mn})$ & 310 \\
\hline 16 May 93 & 28.810 & 98.170 & $5^{+}$ & $3.00(\mathrm{Mn})$ & 309 \\
\hline
\end{tabular}

${ }^{*}(\mathrm{mb})=$ body-wave magnitude; Gutenberg and Richter [1956]; $(\mathrm{Mn})=$ Nuttli magnitude; Nuttli [1973]

$(+)=$ depth constrained by geophysicist 


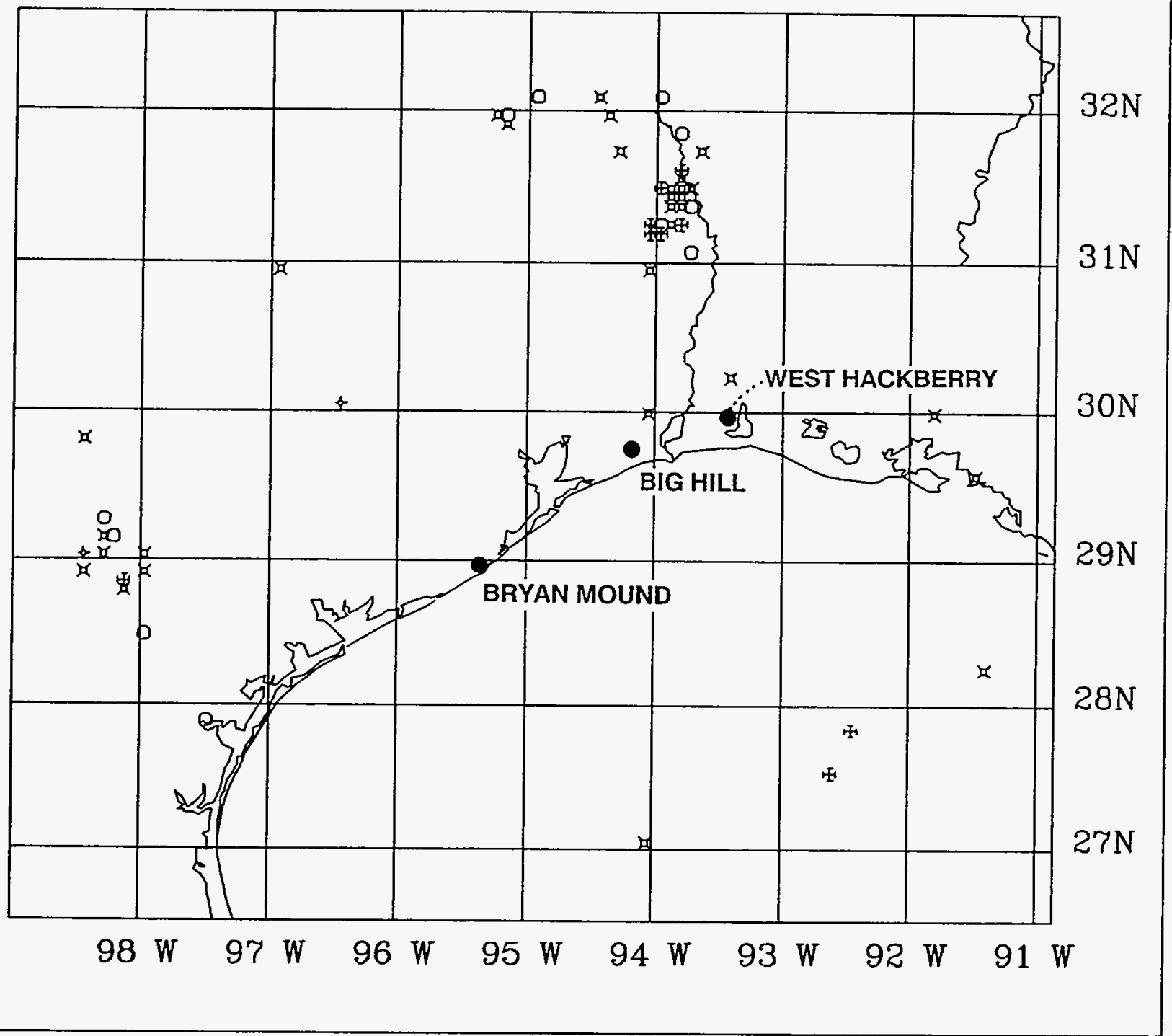

MAGNITUDES:

Computer graphics by Roger N. Hunter, Geophysicist HDRS:[HDF.PUBLC]SR100808.DAT

First date: Nov 5. 1963 Last dele May 16. 1993
? 0
1 口
2
$3 x$
4

U. S. Geological Survey. National Earthquake Information Center Data taken from the Earthquake Data Base System

Figure B-2 Historical seismic events, 05 Nov $63-16$ May 93, within $400 \mathrm{~km}$ radius of Bryan Mound. Magnitudes greater than 2.0 plotted; refer to Table B-1 for listing of individual events. 


\section{Induced Seismicity}

A small possibility exists for inducing earthquake activity as a result of injecting brine into metastable formations at depth. Although this phenomena had been documented at several locations prior to the 1980 characterization report, the more widespread threat has become apparent and questioned by several regulatory agencies. In West Texas, the largest earthquake induced by well injection occurred on 16 Jun 78, and had a magnitude of 4.8 , which cracked plaster and windows in Snyder and neighboring towns [Davis, et al., 1989]. Because well injection does not appear to present environmental risks at Bryan Mound, it is not treated in particular detail in this update.

The effect may be to trigger rather than to cause seismicity, through the mechanism of altering the in situ stress field. Thus, the hazard from fluid injection is not that it can generate sufficient strain energy for release in earthquakes, but that it can locally reduce the effective frictional strength of faults and thus trigger earthquakes where the state of stress and the accumulated strain energy are metastable as a result of natural geologic and tectonic processes. In those cases where injection-induced seismicity was established, pore pressure increases have been the perturbation that triggered the earthquake [Nicholson and Wesson, 1990].

Where the transmissivity and storativity is low in the injection horizon, the more confined the "pressure bulb" will be around the bottom of the well and the more likely that high pore fluid pressures will occur, increasing the concern for earthquake inducement.
Thus the lower the injection pressure is, the less likely the chance of triggering seismicity becomes. Ideally, in situ estimates of transmissivity and storativity should be made at the time of well completion, and used in evaluating the hydrologic environment, and the elastic constants of the reservoir formation. Once baseline conditions are established in operating wells, any increases in apparent transmissivity should be suspect as possible evidence for the opening of fractures or the occurrence of faulting.

At Bryan Mound it is not known with certainty what the frictional stress condition is on nearby growth faults. In other locations that experienced induced seismicity as a result of injection activity, the theoretical threshold for frictional sliding along favorably oriented preexisting fractures, as indicated by the Mohr-Coulomb failure criterion, was exceeded. To date there has not been any indication that injection into brine disposal wells near Bryan Mound would provide a trigger mechanism for any faults. But neither has there been large-scale introduction of brine since the brine pipeline to the Gulf was completed, thus a small amount of uncertainty remains.

The closest major growth fault to Bryan Mound that is active is the Vicksburg Flexure, approximately $10 \mathrm{mi}$ to the northwest. Its rapid down-to-the-coast growth can be documented by pavement breaks along the Gulf Freeway between Houston and Galvelston having up to $5 \mathrm{ft}$ of displacement. However, it is aseismic, apparently because it soles out in the geopressured Vicksburg-Jackson shale. The location of the flexure coincides with the downdip or 
distal edge of Frio deepwater or turbidite sands. [Etter, 1981].

\section{REFERENCES TO APPENDIX B}

Algermissen, S. T., D. M. Perkins, P. C. Thenhous, S. L. Hanson. and B. L. Bender (1990) Probabilistic earthquake acceleration and velocity maps for the United States and Puerto Rico. U. S. Geol Surv. Misc. Field Studies Map MF-2120.

Davis, S. D., W. D. Pennington, and S. M. Carlson (1989) A Compendium of Earthquake Activity in Texas. Texas Bur. Econ. Geol. Circular 89-3. Austin, TX, 27 pp.

Etter, E. M. (ed.) (1981) Houston Area Environmental Geology: Surface Faulting, Ground Subsidence. Houston Geological Society.

Hogan, R. G., et al. (1980) Strategic Petroleum Reserve (SPR) Geological Site Characterization Report: Bryan Mound Salt Dome. Sandia National Laboratories Report SAND80-7111, Albuquerque, NM.

Gutenberg, B., and C. F. Richter (1956) Magnitude and Energy of Earthquakes. Annali die Geofisica, 9 , No. 1, p.1-15.

Nicholson, C., and R. L. Wesson (1990) Earthquake Hazard Associated with Deep Well Injection -- A Report to the U. S. Environmental Protection Agency: U. S. Geol. Surv. Bull. 1951, 74 pp.

Nuttli, O. (1973) Seismic Wave Attenuation and Magnitude Relations for Eastern North America: Jour. Geophys. Res., $\underline{78}$, No. 5, p.876-885.

Pratt, H. R., et al. (1979) Earthquake Damage to Underground Facilities; Rapid Excavation and Tunneling Conf.; ASCE and Am. Inst. Min., Met. and Pet. Engr.; Atlanta, 18-21 June 79.

Stevenson, D. A. (1985) Geopressured-Geothermal Well Development and Seismic Activity in Gulf Coast Louisiana (abs): Earthquake Notes, v. 55, P. 18.

Stevenson, D. A., and J. D. Agnew (1988) Lake Charles, Louisiana, Earthquake of 16 October 1983. Bull. Seism. Soc. Amer., V. 78, No. 4, pp. 1463-74, Aug. 1988.

Verbeek, E. R. (1979) Surface Faults in the Gulf Coastal Plain Between Victoria and Beaumont, Texas. Tectonophysics, $\underline{52}$, p. 373-375. 


\section{APPENDIX C}

Index of Bryan Mound Well Data Used in

Construction of Contour Maps and Sections

Part 1, p. C-2 thru C-4: listing of individual wells (on Figure 1, well location map), and origin

Part 2, p. C-5 thru C-24: listing of stratigraphic marker horizons by depth, as determined from well logs

NOTE: stratigraphic correlation symbols are summarized on Table 1,

Appendix A, p. A-5

C-1 


\section{Part 1 List of Wells used in Maps and Cross Sections}

$\underline{0102-3004}$ are Freeport Sulphur Company wells, except those marked with asterisk are DOE/SPR Cavern Wells; 5001-5050 are Hooker Chemical Company sulphur wells; 6001-6052 are wells D-1 through D-52 (in sequence) from Hogan et al. (1980).

\begin{tabular}{|c|c|c|c|c|}
\hline 0102 & 0440 & 0556 & 0676 & 0956 \\
\hline 0113 & 0445 & 0557 & 0679 & 0975 \\
\hline 0117 & 0449 & 0558 & 0687 & 1005 \\
\hline 0120 & 0467 & 0560 & 0697 & 1001 \\
\hline 0124 & 0469 & 0562 & 0699 & 1012 \\
\hline 0126 & 0476 & 0566 & 0700 & 1013 \\
\hline 0134 & 0481 & 0567 & 0702 & 1014 \\
\hline 0140 & 0482 & 0568 & 0705 & 1015 \\
\hline 0158 & 0492 & 0570 & 0709 & 1017 \\
\hline 0162 & 0494 & 0573 & 0717 & 1019 \\
\hline 0180 & 0496 & 0575 & 0718 & $101 \mathrm{~A}^{*}$ \\
\hline 0186 & 0500 & 0576 & 0719 & $101 C^{*}$ \\
\hline 0190 & 0501 & 0579 & 0727 & 1021 \\
\hline 0197 & 0502 & 0580 & 0780 & 1022 \\
\hline 0200 & 0503 & 0587 & 0783 & 1027 \\
\hline 0204 & 0504 & 0588 & 0784 & $102 B^{*}$ \\
\hline 0211 & 0508 & 0593 & 0793 & $102 C^{*}$ \\
\hline 0265 & 0509 & 0599 & 0797 & 1031 \\
\hline 0305 & 0510 & 0602 & 0804 & 1032 \\
\hline 0309 & 0512 & 0603 & 0806 & 1033 \\
\hline 0311 & 0513 & 0604 & 0809 & $103 B^{*}$ \\
\hline 0316 & 0514 & 0605 & 0813 & $103 C^{*}$ \\
\hline 0317 & 0515 & 0606 & 0814 & 1040 \\
\hline 0331 & 0518 & 0607 & 0815 & 1044 \\
\hline 0343 & 0522 & 0609 & 0818 & 1047 \\
\hline 0350 & 0523 & 0610 & 0820 & $104 A^{*}$ \\
\hline 0354 & 0526 & 0626 & 0827 & $104 \mathrm{~B}^{*}$ \\
\hline 0356 & 0527 & 0637 & 0832 & $104 C^{*}$ \\
\hline 0368 & 0528 & 0638 & 0838 & 1050 \\
\hline 0369 & 0529 & 0639 & 0848 & 1051 \\
\hline 0371 & 0530 & 0641 & 0849 & 1052 \\
\hline 0374 & 0534 & 0642 & 0891 & 1056 \\
\hline 0389 & 0541 & 0643 & 0895 & 1057 \\
\hline 0398 & 0544 & 0652 & 0907 & 1058 \\
\hline 0407 & 0546 & 0653 & 0914 & 1059 \\
\hline 0421 & 0548 & 0659 & 0917 & $105 \mathrm{~B}^{*}$ \\
\hline 0422 & 0551 & 0662 & 0920 & $105 C^{*}$ \\
\hline 0433 & 0552 & 0671 & 0929 & 1060 \\
\hline 0437 & 0553 & 0674 & 0950 & 1062 \\
\hline
\end{tabular}




\begin{tabular}{|c|c|c|c|c|}
\hline 1063 & 1203 & 1356 & 1470 & 1575 \\
\hline 1066 & 1208 & 1357 & 1472 & 1576 \\
\hline 1068 & 1209 & 1358 & 1475 & 1577 \\
\hline 1069 & 1210 & 1360 & 1483 & 1580 \\
\hline $106 A^{*}$ & 1212 & 1364 & 1484 & 1581 \\
\hline $106 \mathrm{~B}^{*}$ & 1213 & 1367 & 1491 & 1582 \\
\hline $106 C^{*}$ & 1216 & 1369 & 1495 & 15583 \\
\hline 1072 & 1223 & 1377 & 1496 & 1584 \\
\hline 1077 & 1224 & 1379 & 1498 & 1586 \\
\hline 1078 & 1225 & 1381 & 1500 & 1589 \\
\hline $107 A^{*}$ & 1226 & 1383 & 1502 & 15 \\
\hline $107 \mathrm{~B}^{*}$ & 1227 & 1386 & 1504 & $15 s$ \\
\hline $107 C^{*}$ & 1240 & 1387 & 1505 & 1593 \\
\hline 1085 & 1242 & 1393 & 1506 & 1594 \\
\hline 1086 & 1246 & 1394 & 1507 & 1595 \\
\hline 1089 & 1253 & 1395 & 1508 & 1596 \\
\hline $108 \mathrm{~A}^{*}$ & 1258 & 1399 & 1509 & 1598 \\
\hline $108 \mathrm{~B}^{*}$ & 1262 & 1402 & 1511 & 1602 \\
\hline $108 C^{*}$ & 1264 & 1403 & 1512 & 1604 \\
\hline 1090 & 1268 & 1406 & 1520 & 160 \\
\hline 1097 & 1272 & 1411 & 1525 & 1607 \\
\hline $109 A^{*}$ & 1273 & 1412 & 1528 & 1608 \\
\hline $109 \mathrm{~B}^{*}$ & 1276 & 1421 & 1530 & 1610 \\
\hline $109 C^{*}$ & 1278 & 1422 & 1535 & 1612 \\
\hline 1100 & 1280 & 1423 & 15536 & 1617 \\
\hline 1107 & 1282 & 1424 & 1538 & 116 \\
\hline 1109 & 1283 & 1428 & 1539 & 161 \\
\hline $110 A^{*}$ & 1287 & 1429 & 1542 & 1620 \\
\hline $110 \mathrm{~B}^{*}$ & 1288 & 1434 & 1544 & 1622 \\
\hline $110 C^{*}$ & 1292 & 1437 & 1545 & 1623 \\
\hline 1111 & 1296 & 1441 & 1549 & 1624 \\
\hline 1113 & 1297 & 1442 & 1550 & 1626 \\
\hline $111 A^{*}$ & 1301 & 1445 & 1552 & $16^{2}$ \\
\hline $111 B^{*}$ & 1306 & 1446 & 1553 & 1630 \\
\hline $112 A^{*}$ & 1308 & 1447 & 1554 & 1631 \\
\hline $112 C^{*}$ & 1310 & 1448 & 1555 & 1632 \\
\hline $113 A^{*}$ & 1316 & 1449 & 1556 & 1700 \\
\hline $113 B^{*}$ & 1320 & 1450 & 1557 & 1703 \\
\hline $114 A^{*}$ & 1327 & 1452 & 1558 & 1709 \\
\hline $114 \mathrm{~B}^{*}$ & 1332 & 1453 & 1559 & 1712 \\
\hline $115 A^{*}$ & 1335 & 14556 & 1560 & 1720 \\
\hline $115 \mathrm{~B}^{*}$ & 1343 & 1459 & 1562 & 172 \\
\hline $116 A^{*}$ & 1350 & 1464 & 1565 & 1725 \\
\hline $116 \mathrm{~B}^{*}$ & 1351 & 1468 & 1567 & 1726 \\
\hline 1201 & 1352 & 1469 & 1570 & 1729 \\
\hline
\end{tabular}

\section{C-3}




\begin{tabular}{|c|c|c|c|c|}
\hline 1733 & 1913 & 2194 & 5043 & 6039 \\
\hline 1735 & 1922 & 2202 & 5044 & 6040 \\
\hline 1737 & 1929 & 2213 & 5045 & 6041 \\
\hline 1742 & 1931 & 2214 & 5046 & 6042 \\
\hline 1743 & 1934 & 2242 & 5047 & 6043 \\
\hline 1744 & 1936 & 2252 & 5048 & 6044 \\
\hline 1746 & 1939 & 2618 & 5049 & 6045 \\
\hline 1751 & 1940 & 3002 & 5050 & 6046 \\
\hline 1758 & 1942 & 3003 & 6001 & 6047 \\
\hline 1761 & 1959 & 3004 & 6002 & 6048 \\
\hline 1770 & 1960 & 5001 & 6003 & 6049 \\
\hline 1778 & 1973 & 5005 & 6004 & 6050 \\
\hline 1781 & 1977 & 5006 & 6005 & 6051 \\
\hline 1791 & 1978 & 5012 & 6006 & 6052 \\
\hline 1792 & 1988 & 5013 & 6007 & DOW1 \\
\hline 1794 & 1994 & 5013 & 6008 & Dow2 \\
\hline 1801 & 2000 & 5014 & 6009 & DOW3 \\
\hline 1806 & 2005 & 5015 & 6010 & DOW4 \\
\hline 1809 & 2010 & 5016 & 6011 & DOW5 \\
\hline 1813 & 2021 & 5017 & 6012 & FEL2 \\
\hline 1814 & 2023 & 5018 & 6013 & \\
\hline 1817 & 2029 & 5019 & 6014 & Off Map \\
\hline 1822 & 2031 & 5020 & 6015 & AMER \\
\hline 1823 & 2035 & 5021 & 6016 & BD-1 \\
\hline 1827 & 2043 & 5022 & 6017 & BD1A \\
\hline 1838 & 2046 & 5023 & 6018 & BD2A \\
\hline 1840 & 2062 & 5024 & 6019 & BD2B \\
\hline 1841 & 2074 & 5025 & 6020 & BD3A \\
\hline 1842 & 2078 & 5026 & 6021 & BD3B \\
\hline 1848 & 2087 & 5027 & 6022 & BHP1 \\
\hline 1849 & 2096 & 5028 & 6023 & DWFE \\
\hline 1850 & 2105 & 5029 & 6024 & DWFR \\
\hline 1853 & 2118 & 5030 & 5025 & $\mathrm{RE} 1 \mathrm{~A}$ \\
\hline 1854 & 2123 & 5031 & 6026 & RE2A \\
\hline 1855 & 2124 & 5032 & 6027 & RE4A \\
\hline 1866 & 2125 & 5033 & 6028 & RE4B \\
\hline 1873 & 2127 & 5034 & 6029 & RE4C \\
\hline 1876 & 2129 & 5035 & 6030 & RE5A \\
\hline 1877 & 2130 & 5036 & 6031 & RE5B \\
\hline 1885 & 2131 & 5037 & 6032 & RE5C \\
\hline 1891 & 2140 & 5038 & 6034 & \\
\hline 1898 & 2145 & 5039 & 6035 & \\
\hline 1902 & 2157 & 5040 & 6036 & \\
\hline 1906 & 2172 & 5041 & 6037 & \\
\hline 1912 & 2186 & 5042 & 6038 & \\
\hline
\end{tabular}




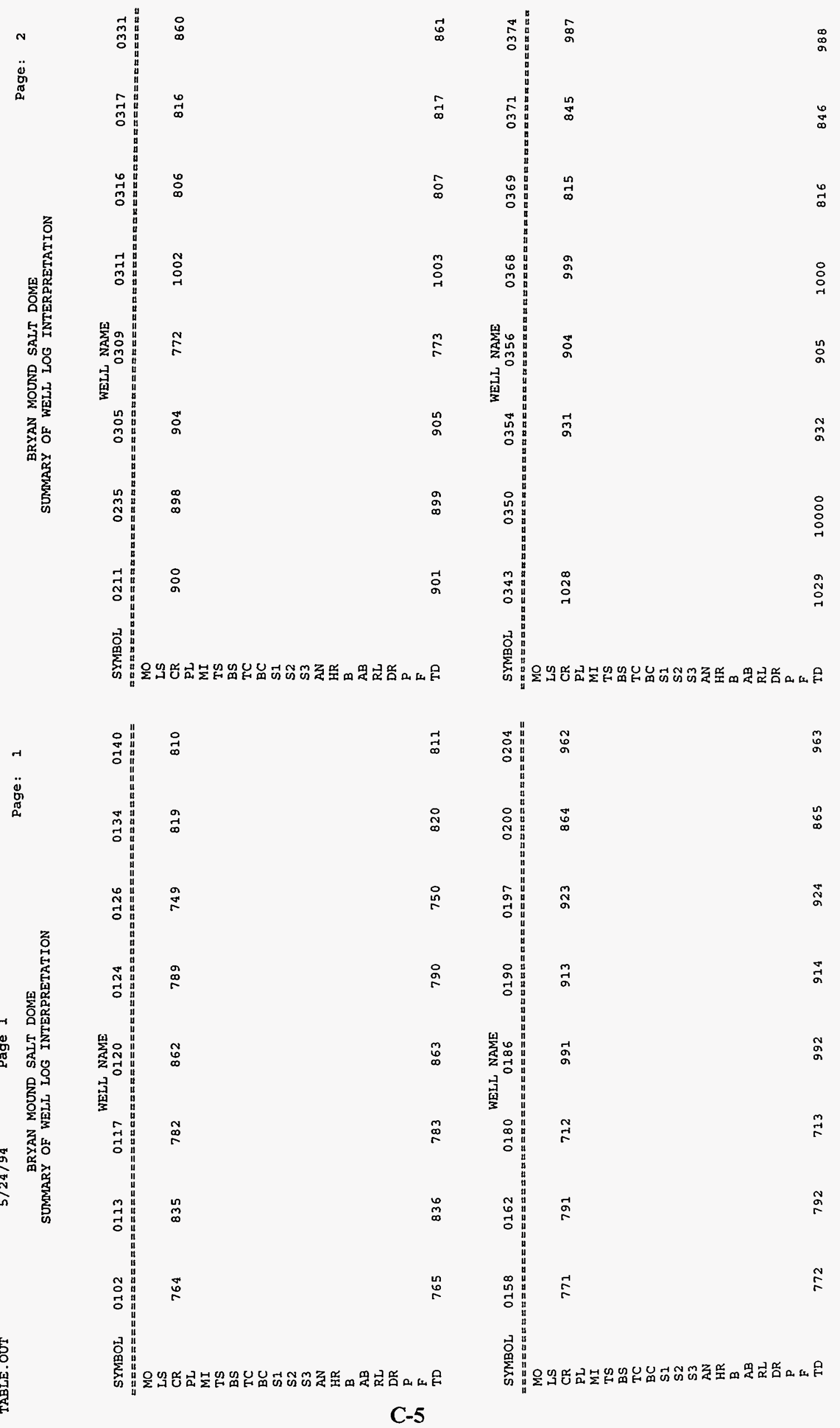

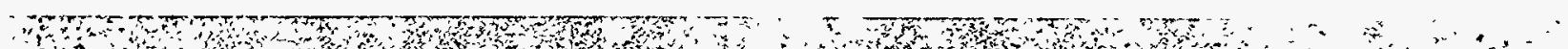




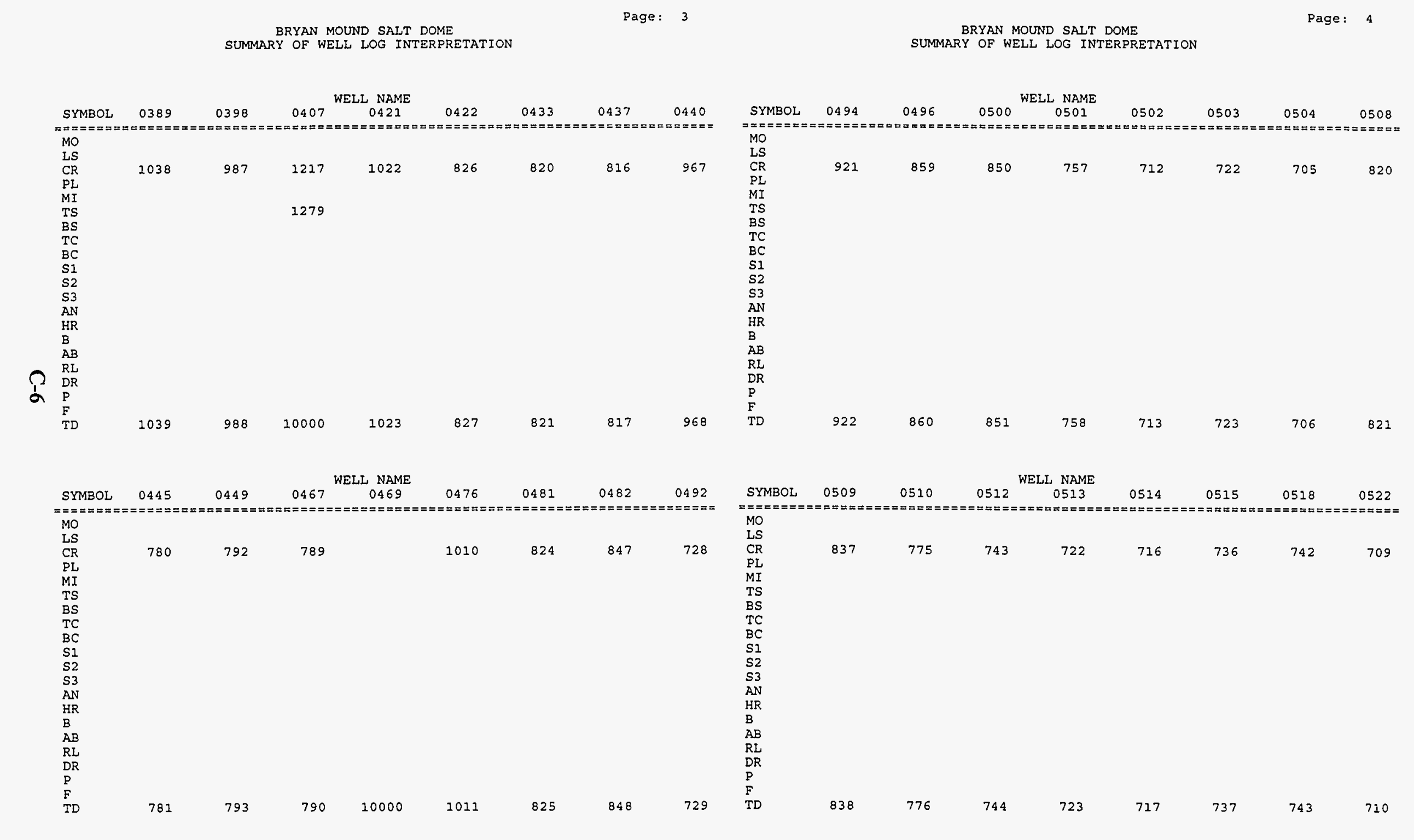


BRYAN MOUND SALT DOME

BRYAN MOUND SALT DOME
SUMMARY OF WELL LOG INTERPRETATION
Page: 5

BRYAN MOUND SALT DOME

SUMMARY OF WELL LOG INTERPRETATION

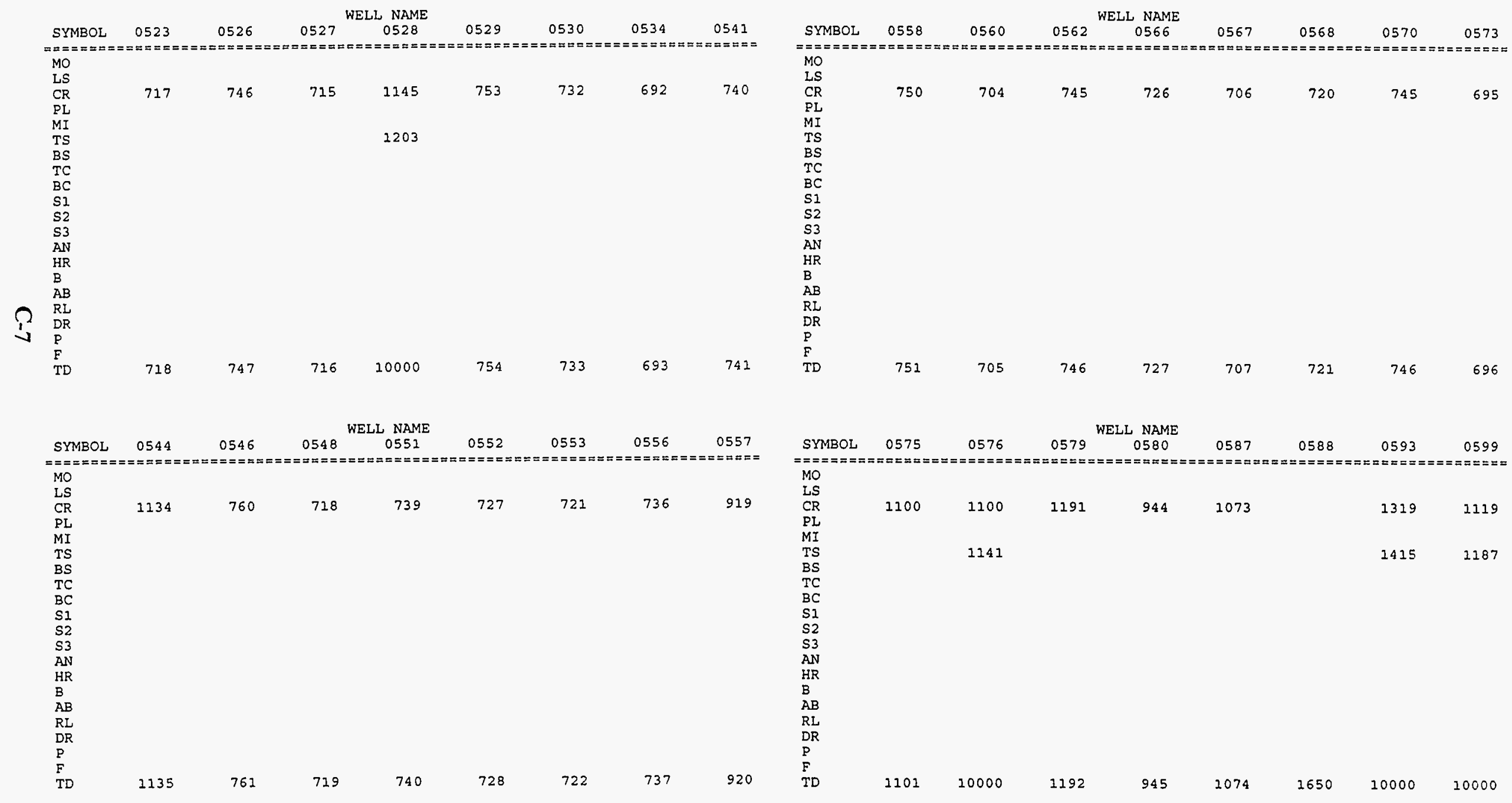



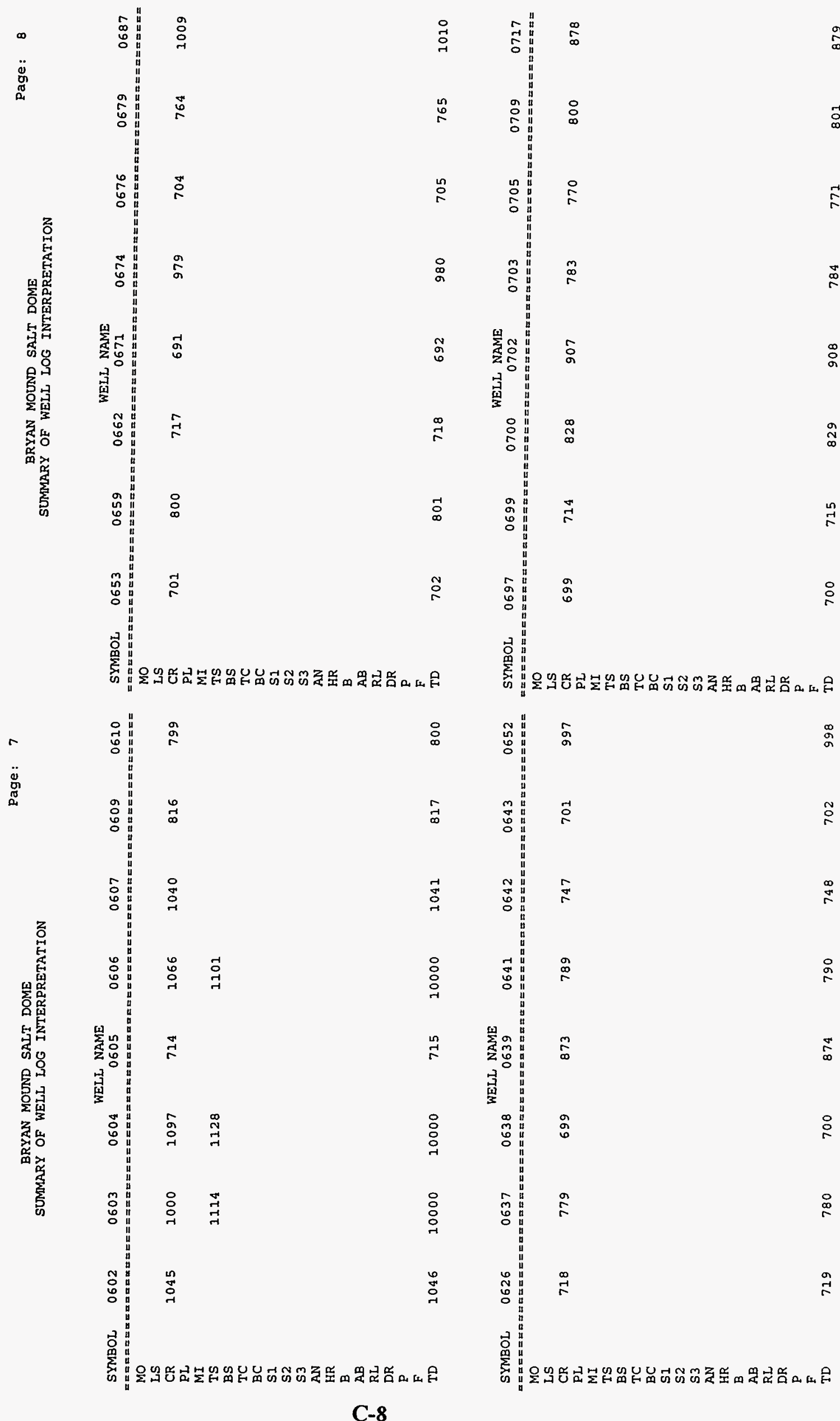

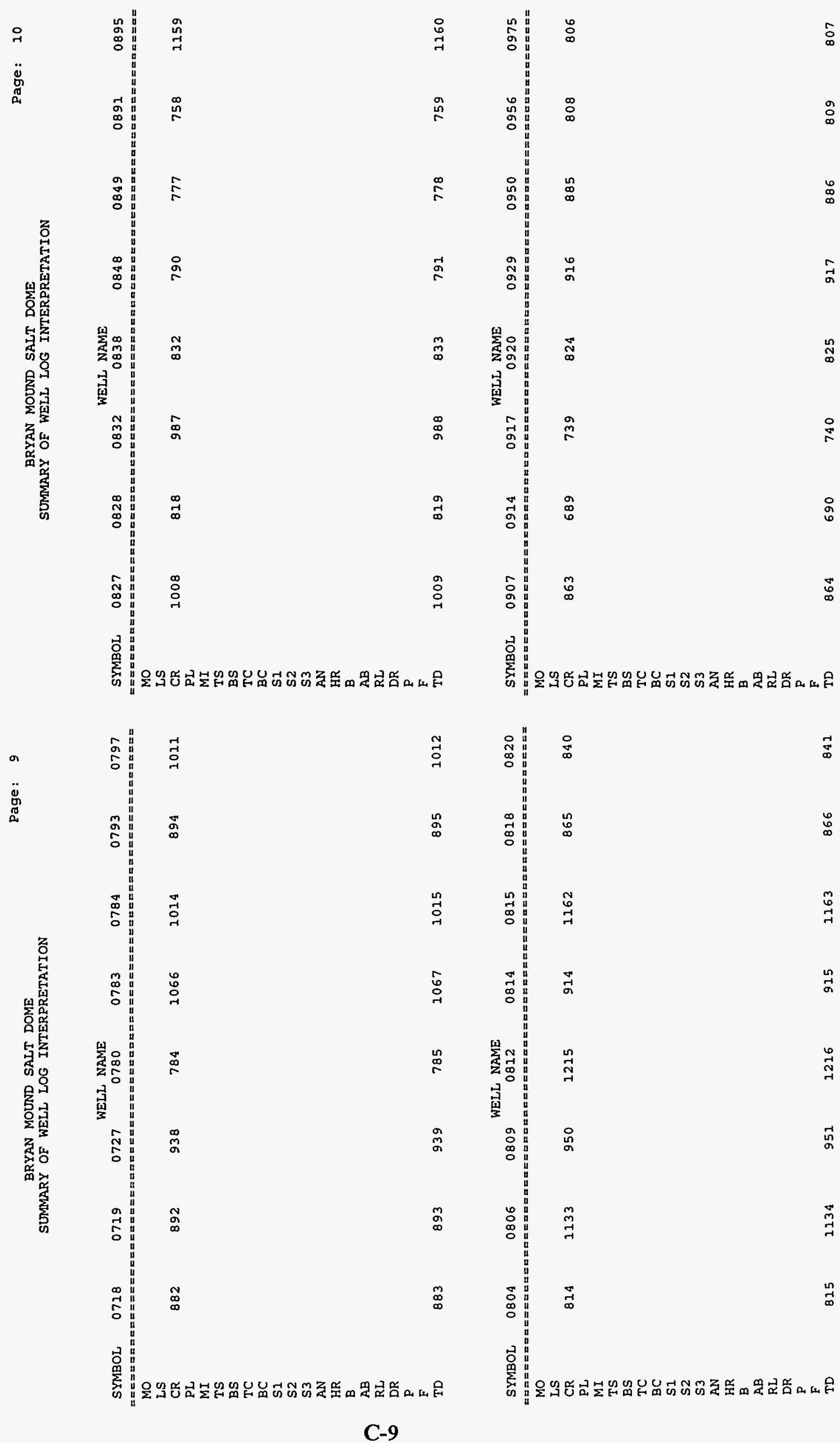


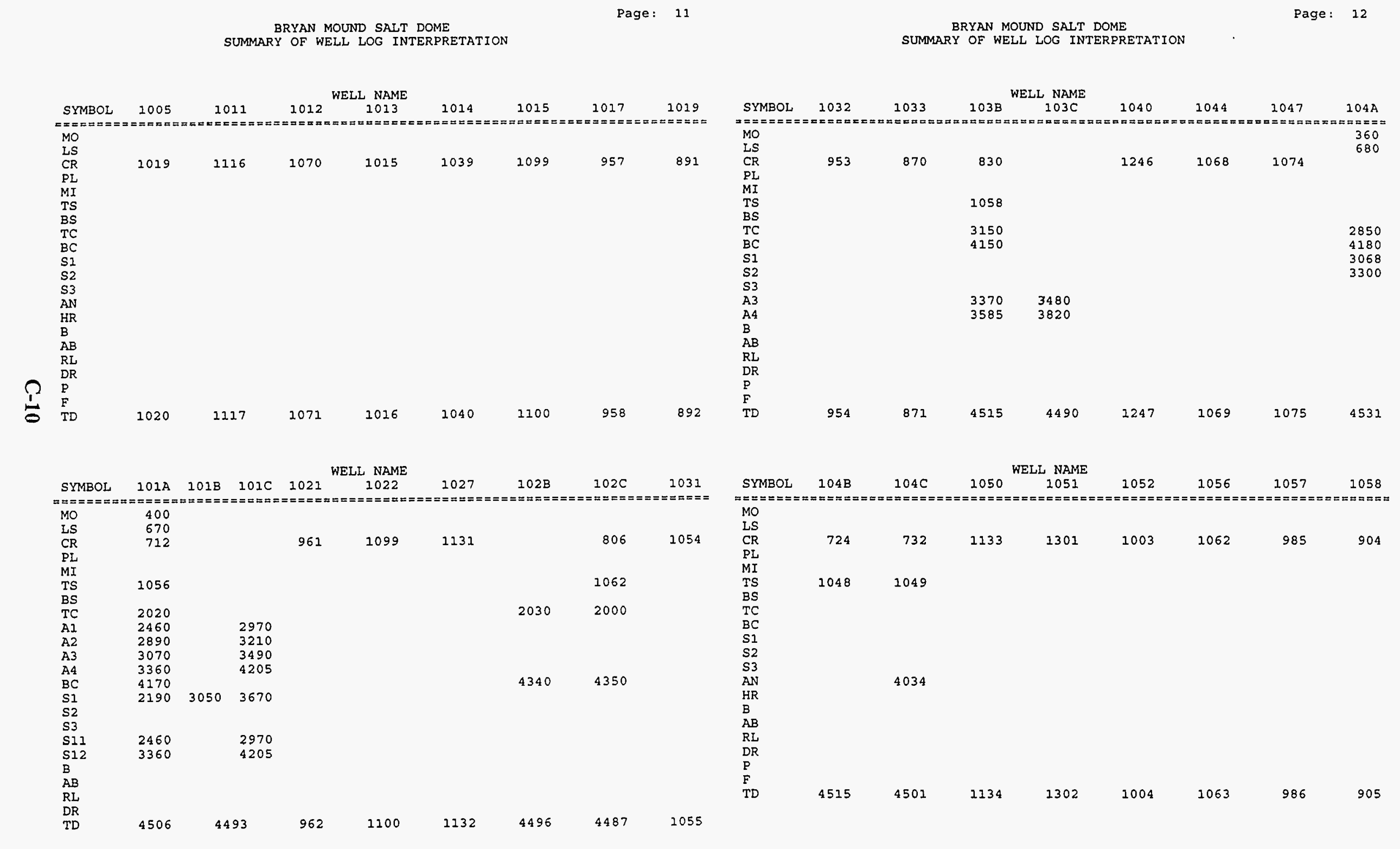




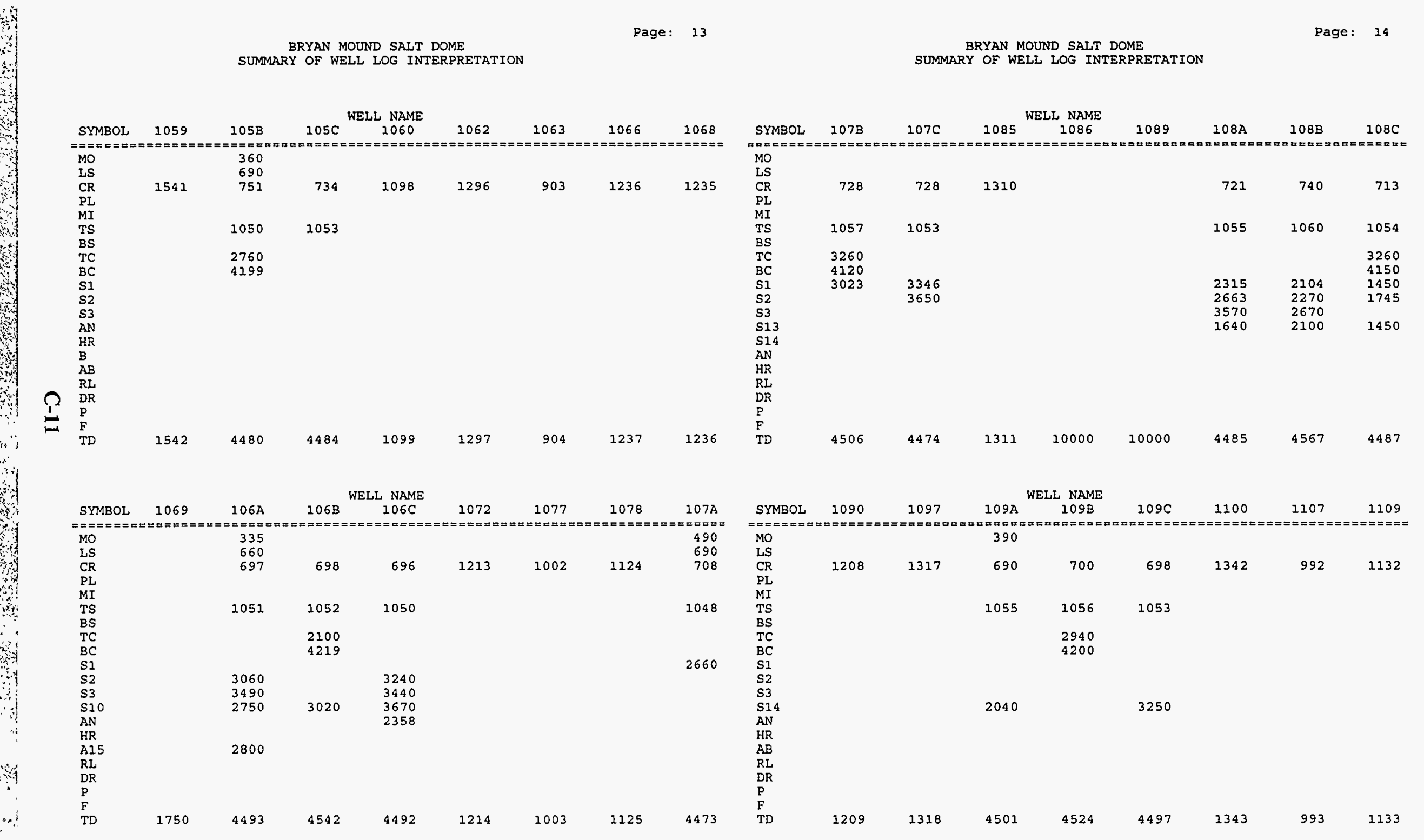


BRYAN MOUND SALT DOME

\begin{tabular}{|c|c|c|c|c|c|c|c|c|c|c|c|c|c|c|c|c|c|}
\hline \multicolumn{9}{|c|}{ WELL NAME } & \multicolumn{9}{|c|}{ WELL NAME } \\
\hline SYMBOL & $110 \mathrm{~A}$ & $\begin{aligned} & 110 \mathrm{~B} \\
=\approx \pi x==\mathrm{E} & \end{aligned}$ & $\begin{array}{l}110 C \\
=x==x=\pi\end{array}$ & $=1111$ & $\begin{array}{l}1113 \\
== \pm=x=\end{array}$ & $\begin{array}{l}111 \mathrm{~A} \\
=x==5\end{array}$ & $\begin{array}{l}111 \mathrm{~B} \\
==x=x=\end{array}$ & $\begin{array}{l}112 \mathrm{~A} \\
== \pm= \pm=\end{array}$ & $\begin{array}{l}\text { SYMBOL } \\
=\approx \#= \pm=E=5\end{array}$ & $\begin{array}{l}116 \mathrm{~B} \\
==0=0\end{array}$ & $\begin{array}{l}1201 \\
n=\pi x=x\end{array}$ & $\begin{array}{l}1203 \\
=E A=E\end{array}$ & $\begin{array}{c}1208 \\
=c=c=0\end{array}$ & $\begin{array}{r}1209 \\
=12=9\end{array}$ & 1210 & 1212 & 2213 \\
\hline MO & 380 & & & & & 415 & & 315 & MO & & & & & & & & \\
\hline LS & $\begin{array}{l}670 \\
730\end{array}$ & & & & & $\begin{array}{l}835 \\
916\end{array}$ & & 660 & $\begin{array}{l}\mathrm{LS} \\
\mathrm{CR}\end{array}$ & & 1021 & 822 & & 1220 & 915 & & 916 \\
\hline $\begin{array}{l}\mathrm{CR} \\
\mathrm{PL} \\
\mathrm{MI}\end{array}$ & 730 & 732 & 729 & 952 & 957 & & & & $\begin{array}{l}\mathrm{CR} \\
\mathrm{PL} \\
\mathrm{MI}\end{array}$ & & 1021 & 822 & 1342 & 1220 & 915 & 2135 & 916 \\
\hline $\begin{array}{l}\text { TS } \\
\text { BS }\end{array}$ & 1058 & 1059 & 1056 & & & 1071 & 1072 & & $\begin{array}{l}\text { TS } \\
\text { BS }\end{array}$ & & & & & & & & \\
\hline TC & 2110 & & & & & 3130 & & & $T C$ & & & & & & & & \\
\hline BC & 4250 & & & & & 4170 & & & BC & & & & & & & & \\
\hline SI & 2185 & & 2103 & & & & & & s1 & & & & & & & & \\
\hline s2 & 2399 & & 2868 & & & & & & s2 & & & & & & & & \\
\hline s3 & 3642 & 3720 & 3665 & & & & & & 53 & & & & & & & & \\
\hline AN & 3740 & & 3730 & & & & & & AN & & & & & & & & \\
\hline $\mathrm{HR}$ & & & & & & & & & HR & & & & & & & & \\
\hline B & & & & & & & & & B & & & & & & & & \\
\hline $\begin{array}{l}A B \\
R L\end{array}$ & & & & & & & & & $\begin{array}{l}A B \\
R L\end{array}$ & & & & & & & & \\
\hline$D R$ & & & & & & & & & $\mathrm{DR}$ & & & & & & & & \\
\hline P & & & & & & & & & P & & & & & & & & \\
\hline TD & 4488 & 4493 & 4480 & 953 & 958 & 4494 & 4503 & 4489 & $\mathrm{TD}$ & 10000 & 1022 & 823 & 1343 & 2221 & 916 & 1136 & 917 \\
\hline & & & & LL NAME & & & & & & & & & WELL NAME & & & & \\
\hline SYMBOL & $112 \mathrm{C}$ & $113 \mathrm{~A}$ & $113 \mathrm{~B}$ & $114 \mathrm{~A}$ & $114 \mathrm{~B}$ & $215 \mathrm{~A}$ & $115 \mathrm{~B}$ & $216 \mathrm{~A}$ & SYMBOL & 1216 & 1223 & 1224 & 1225 & 1226 & 2227 & 1240 & 1242 \\
\hline$==x==x=0$ & $x=z:==$ & & $m=x=2 x=$ & & 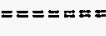 & $==x===-$ & & $======$ & 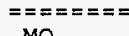 & $=2=2=0$ & & $== \pm= \pm 3$ & $== \pm= \pm$ & & $====$ & $==5=$ & 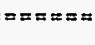 \\
\hline MO & & & & & & 450 & & 430 & $\begin{array}{l}\text { MO } \\
\text { LS }\end{array}$ & & & & & & & & \\
\hline $\mathrm{CR}$ & 719 & & & & & & & & CR & 1089 & 1070 & 898 & 1398 & 904 & 1337 & 1414 & 1046 \\
\hline $\mathrm{PL}$ & & & & & & & & & $\mathrm{PL}$ & & & & & & & & \\
\hline MI & & & & & & & & & MI & & & & & & & & \\
\hline TS & 1051 & & & & & & & & TS & & & & & & & & \\
\hline BS & & & & & & & & & BS & & & & & & & & \\
\hline $\mathrm{TC}$ & 2930 & 2130 & & 2130 & & 2150 & & 2150 & TC & & & & & & & & \\
\hline $\mathrm{BC}$ & 4180 & 4220 & & 4180 & & 4240 & & 4270 & $B C$ & & & & & & & & \\
\hline S1 & & 2990 & 3463 & & & & & & s1 & & & & & & & & \\
\hline \$2 & & & & & & & & & \$2 & & & & & & & & \\
\hline S3 & & & & & & & & & \$3 & & & & & & & & \\
\hline $\mathrm{KI}$ & & & & 3050 & 3130 & & & & AN & & & & & & & & \\
\hline $\mathrm{K} 2$ & & & & 3150 & 3230 & & & & $\mathrm{HR}$ & & & & & & & & \\
\hline B & & & & & & & & & B & & & & & & & & \\
\hline$A B$ & & & & & & & & & $\begin{array}{l}A B \\
R L\end{array}$ & & & & & & & & \\
\hline $\mathrm{DR}$ & & & & & & & & & $\mathrm{DR}$ & & & & & & & & \\
\hline$P$ & & & & & & & & & $\begin{array}{l}\mathrm{P} \\
\mathrm{F}\end{array}$ & & & & & & & & \\
\hline TD & 4483 & 10000 & 10000 & 10000 & 10000 & 10000 & 10000 & 10000 & TD & 1090 & 1071 & 899 & 1399 & 905 & 1338 & 1415 & 1047 \\
\hline
\end{tabular}




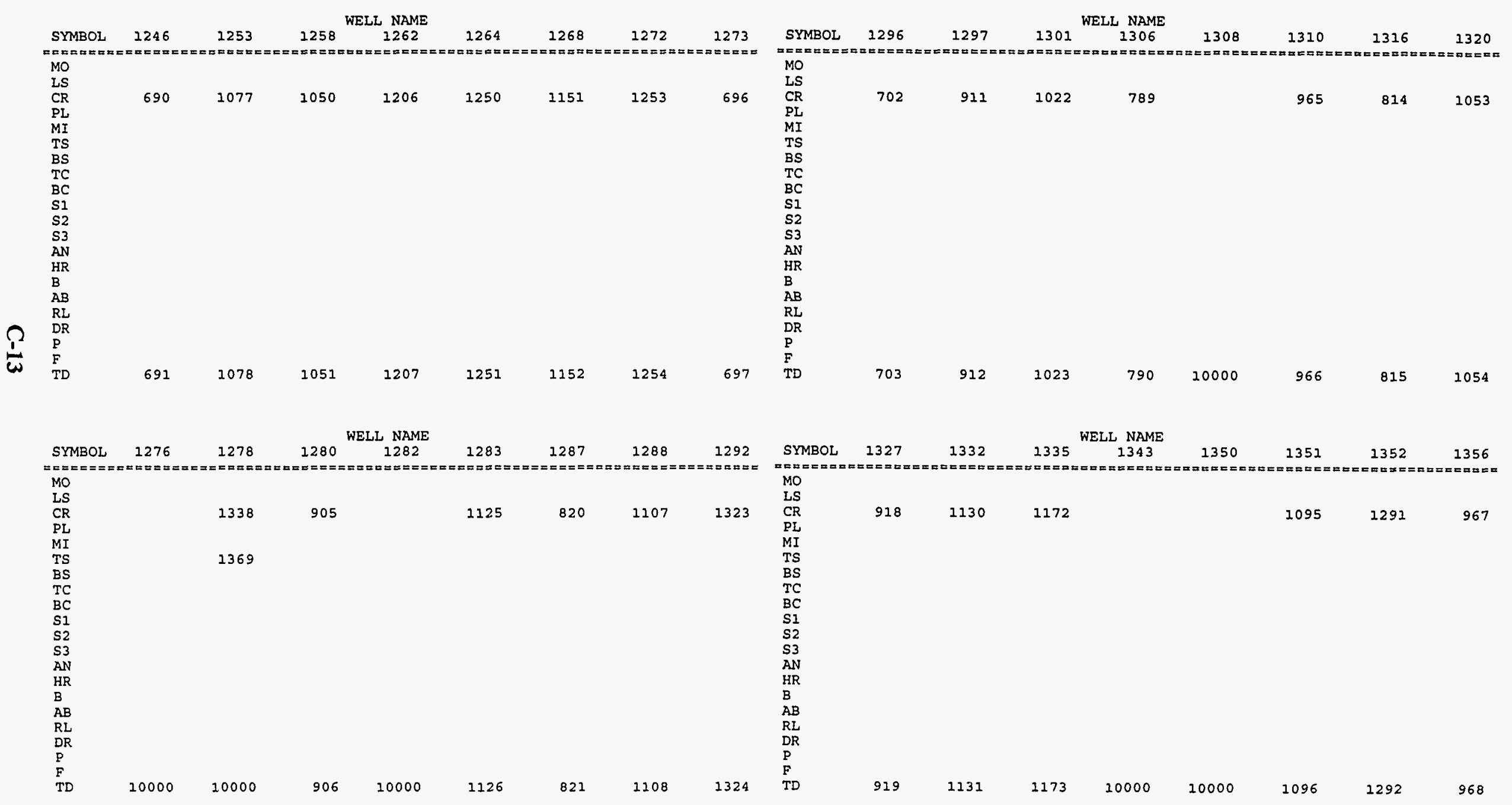


BRYAN MOUND SALT DOME

BRYAN MOUND SALT DOME
SUMMARY OF WELL LOG INTERPRETATION

SUMMARY OF WELL LOG INTERPRETATION

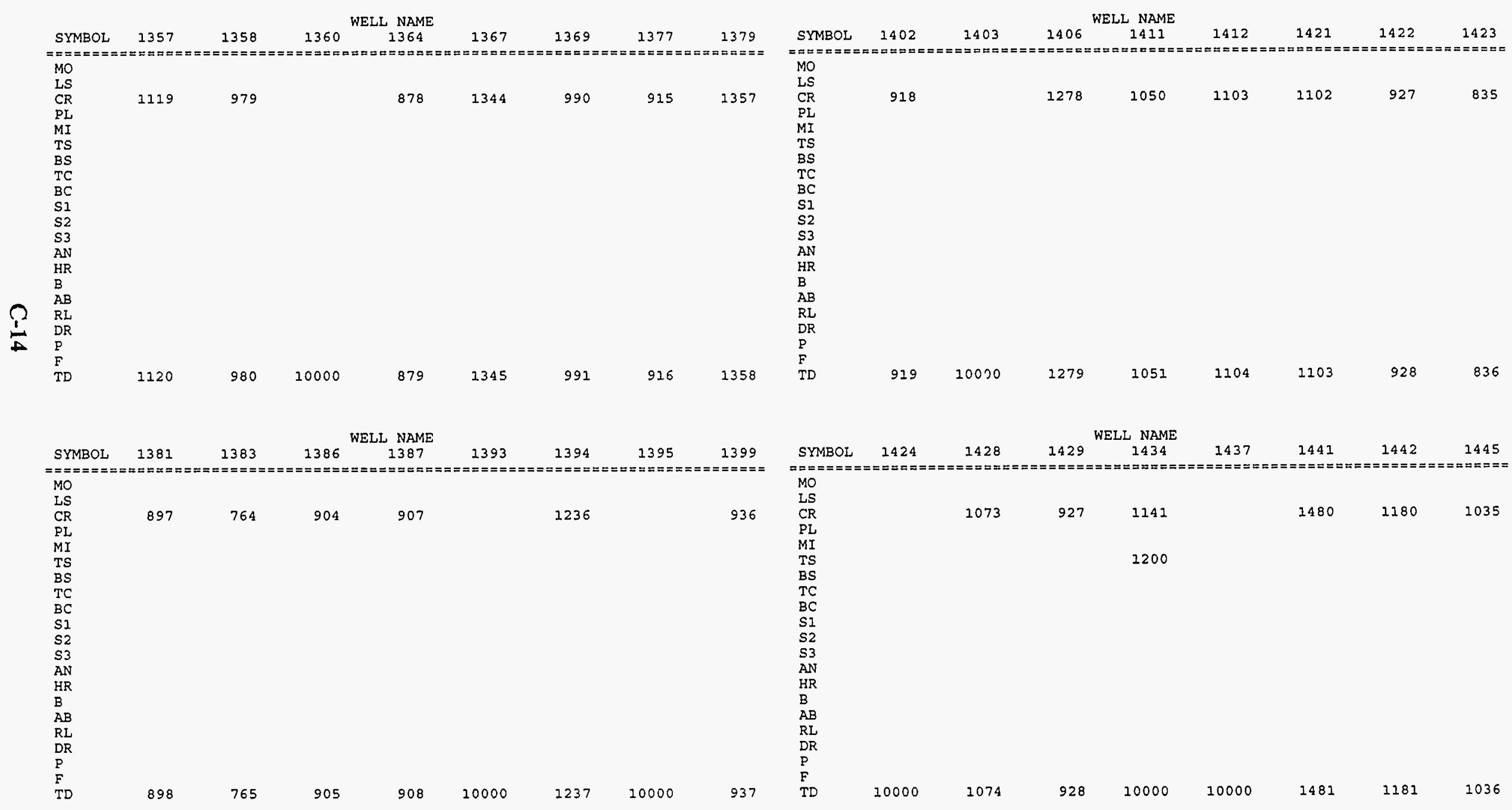


BRYAN MOUND SALT DOME SUMMARY OF WELL LOG INTERPRETATION
Page: 23

BRYAN MOUND SATT DOME SUMMARY OF WELI LOG INTERPRETATION
Page: 22
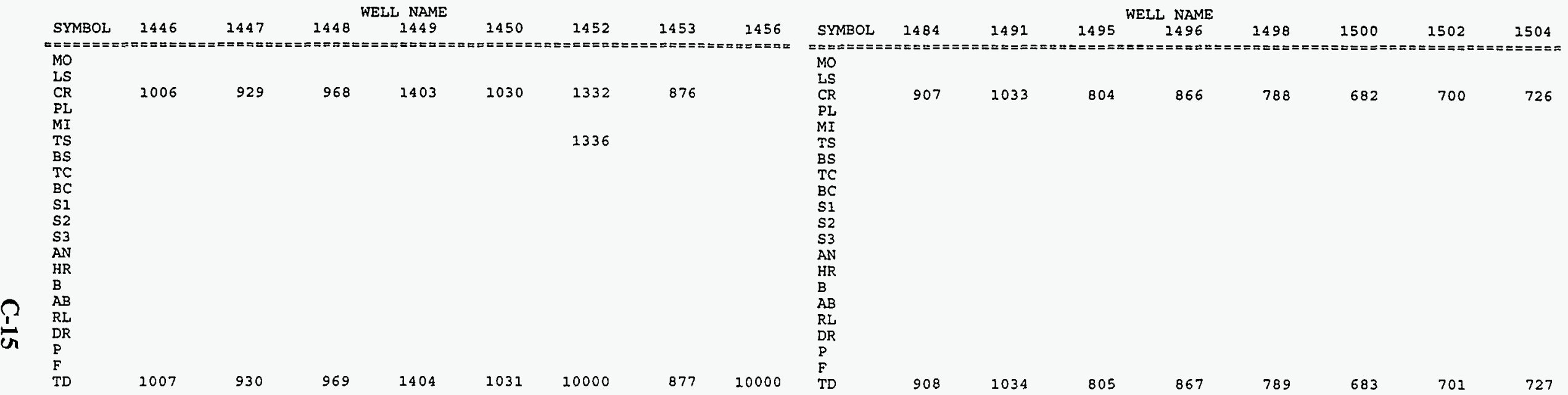

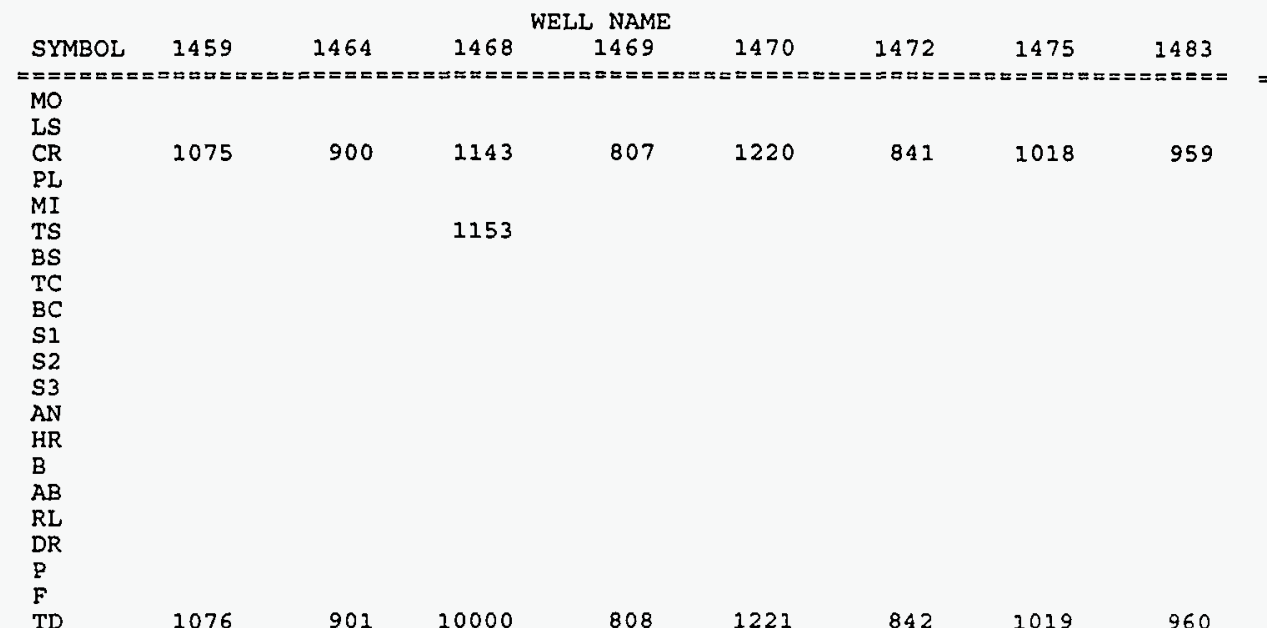

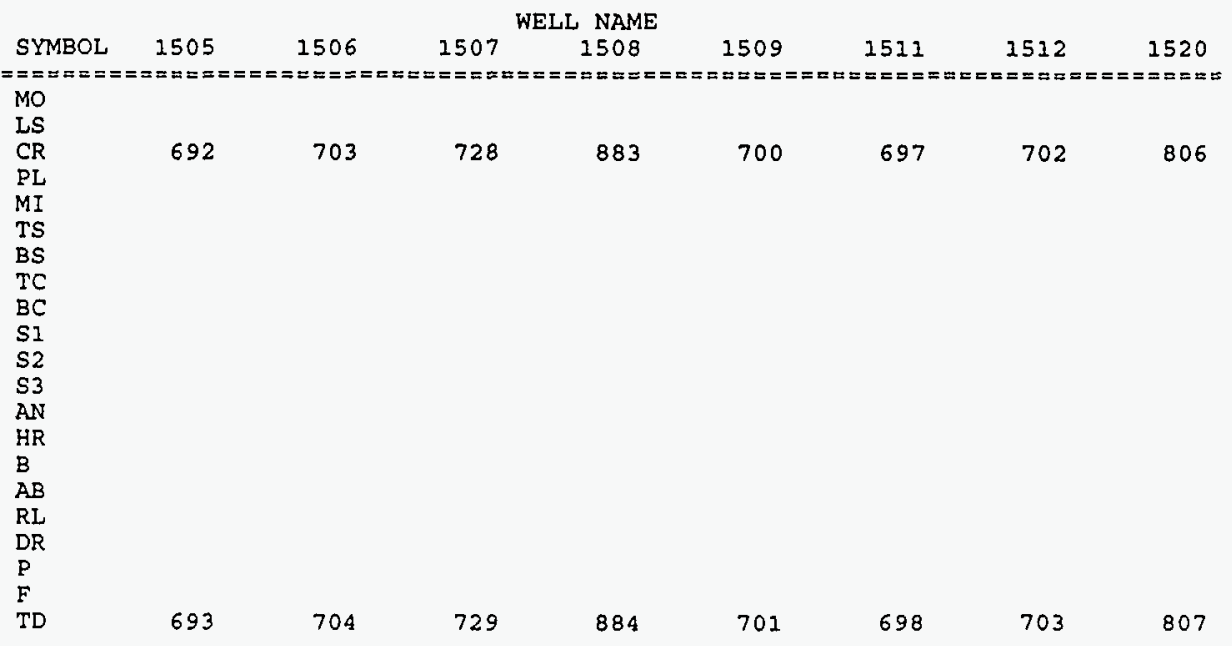


BRYAN MOUND SALT DOME

Page: 23

SUMMARY OF WELL LOG INTERPRETATION

BRYAN MOUND SALT DOME

Page: 24

SUMMARY OF WELL LOG INTERPRETATION

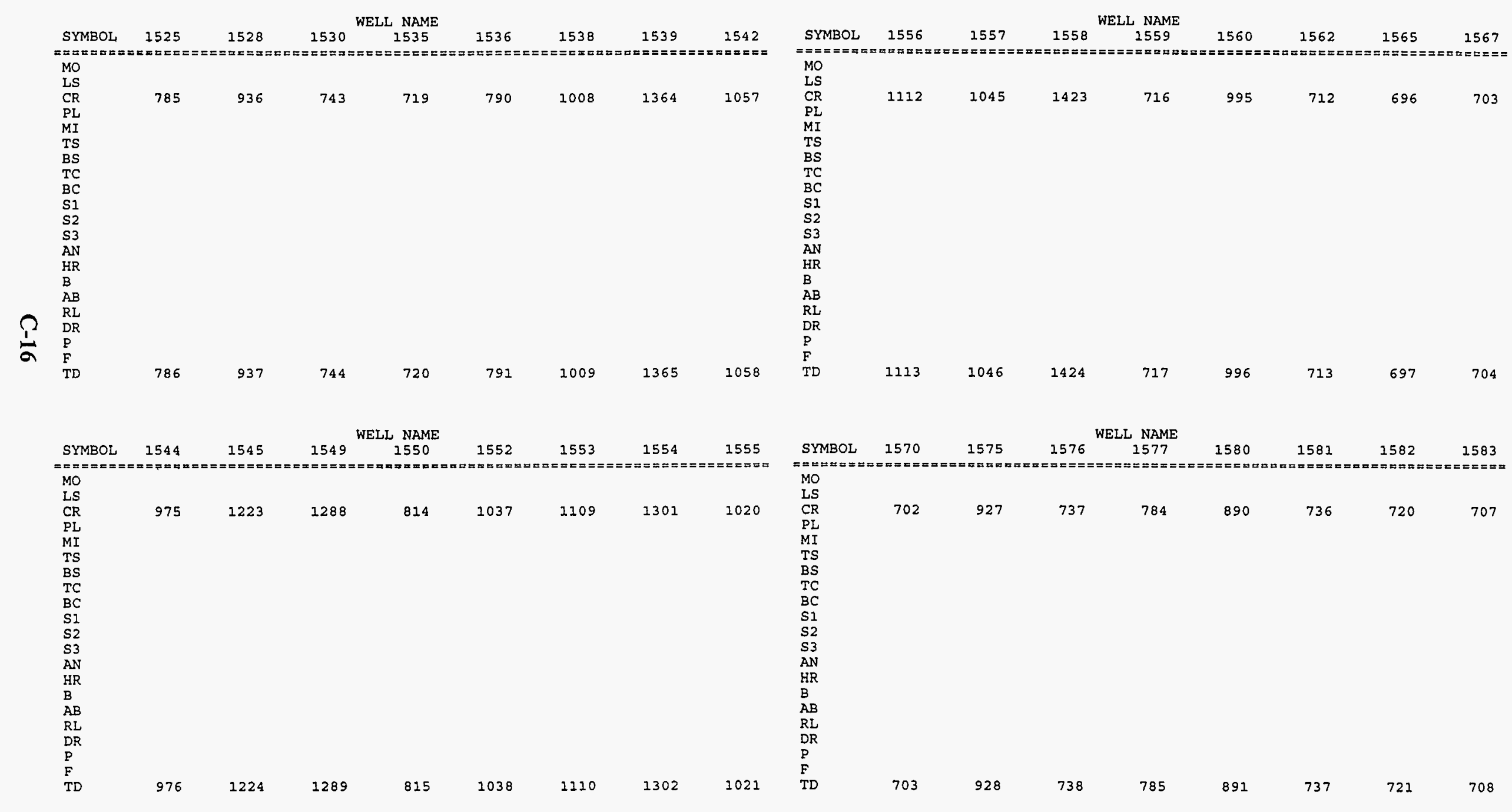


BRYAN MOUND SALT DOME SUMMARY OF WELL LOG INTERPRETATION
Page : 25
Page: 26 SUMMARY OF WELL LOG INTERPRETATION

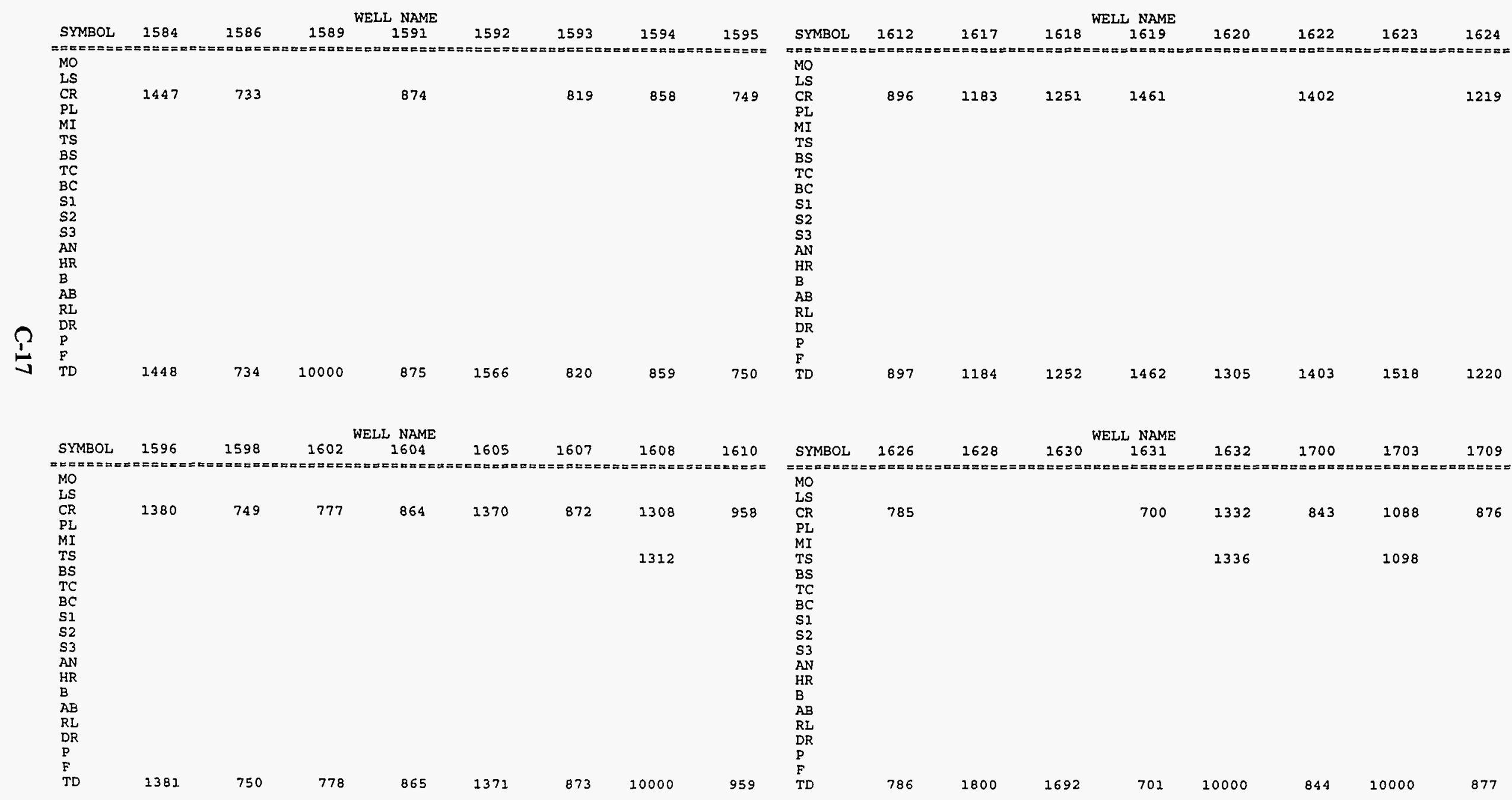




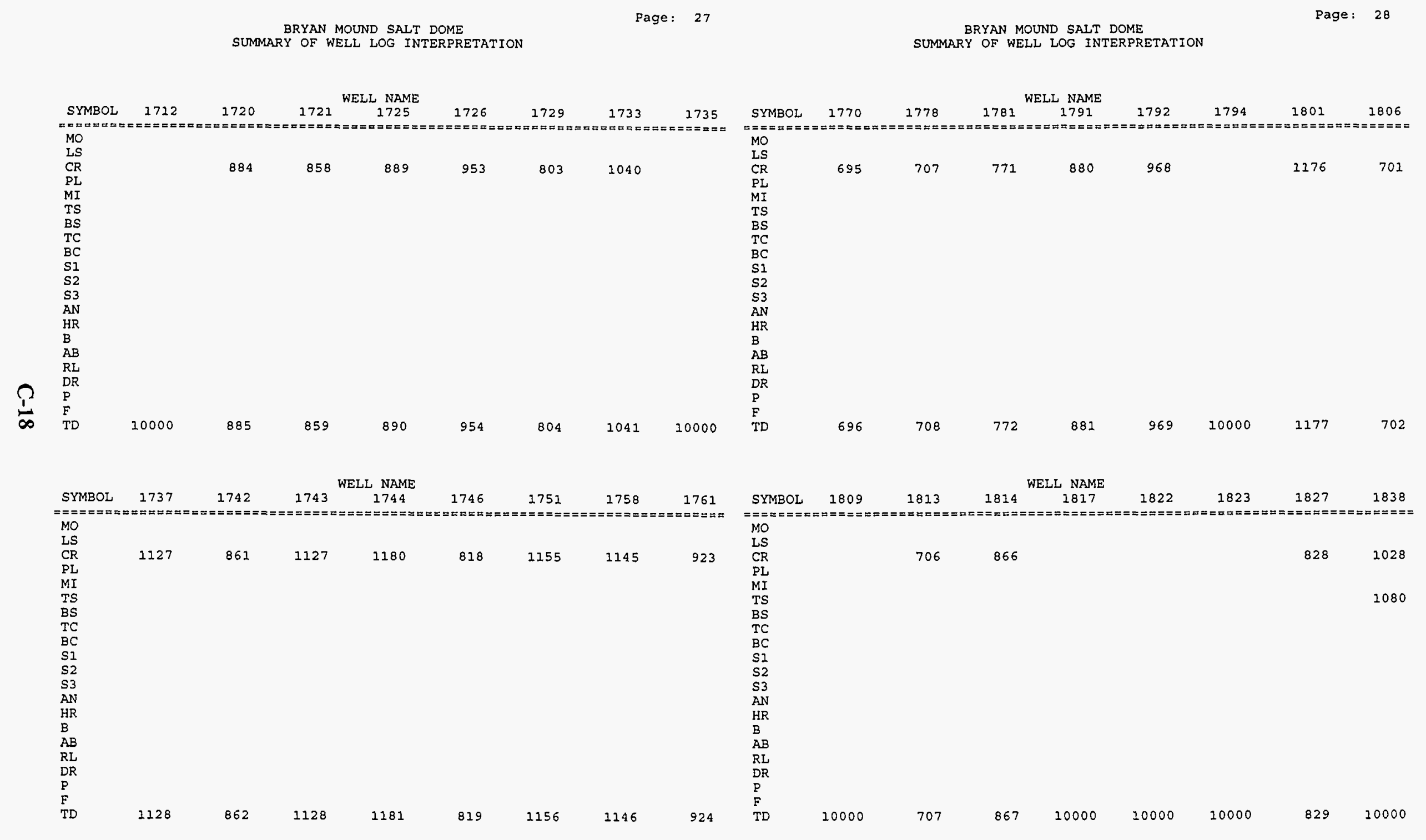




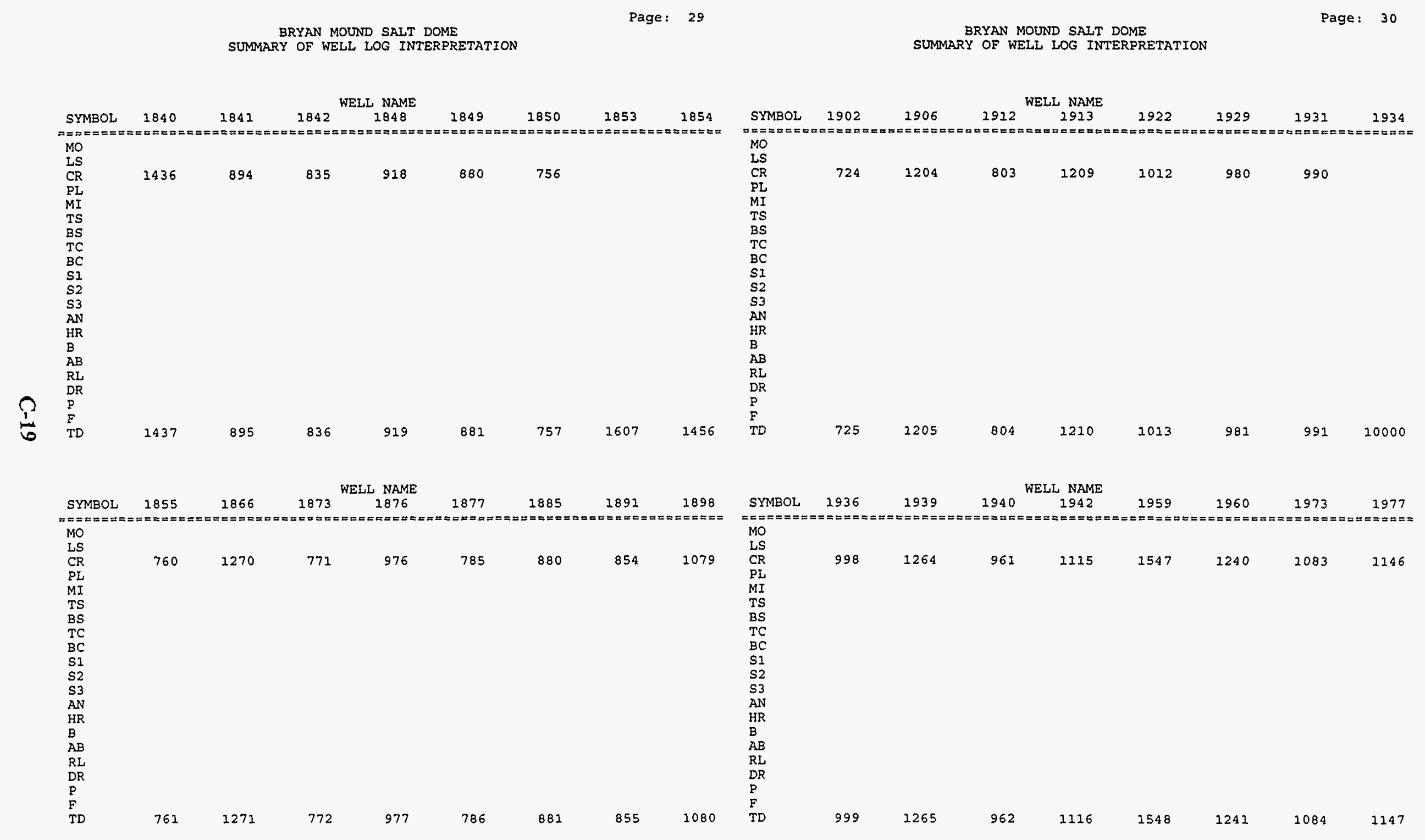


BRYAN MOUND SALT DOME

Page: 31
BRYAN MOUND SALT DOME

Page: 32

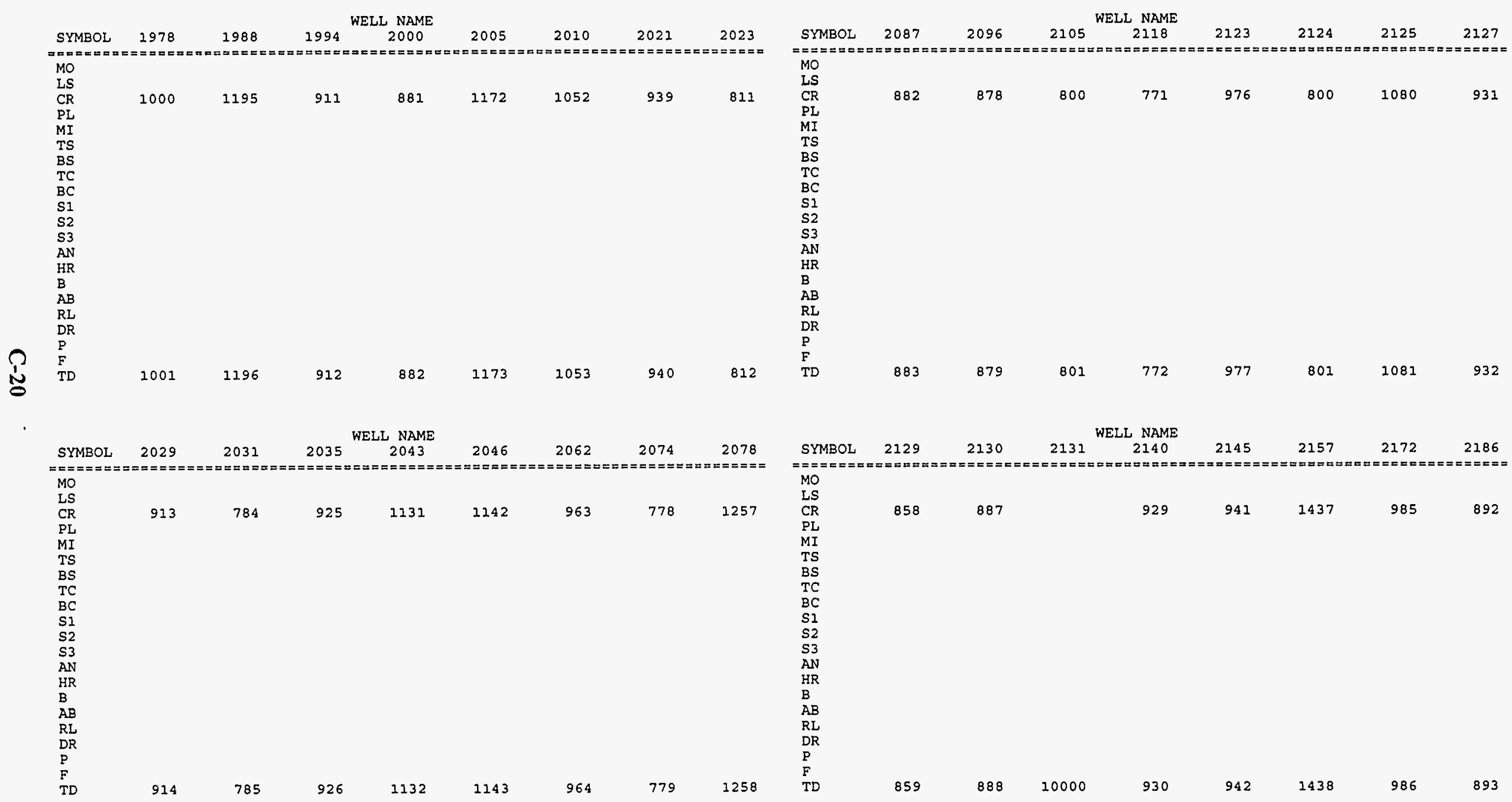




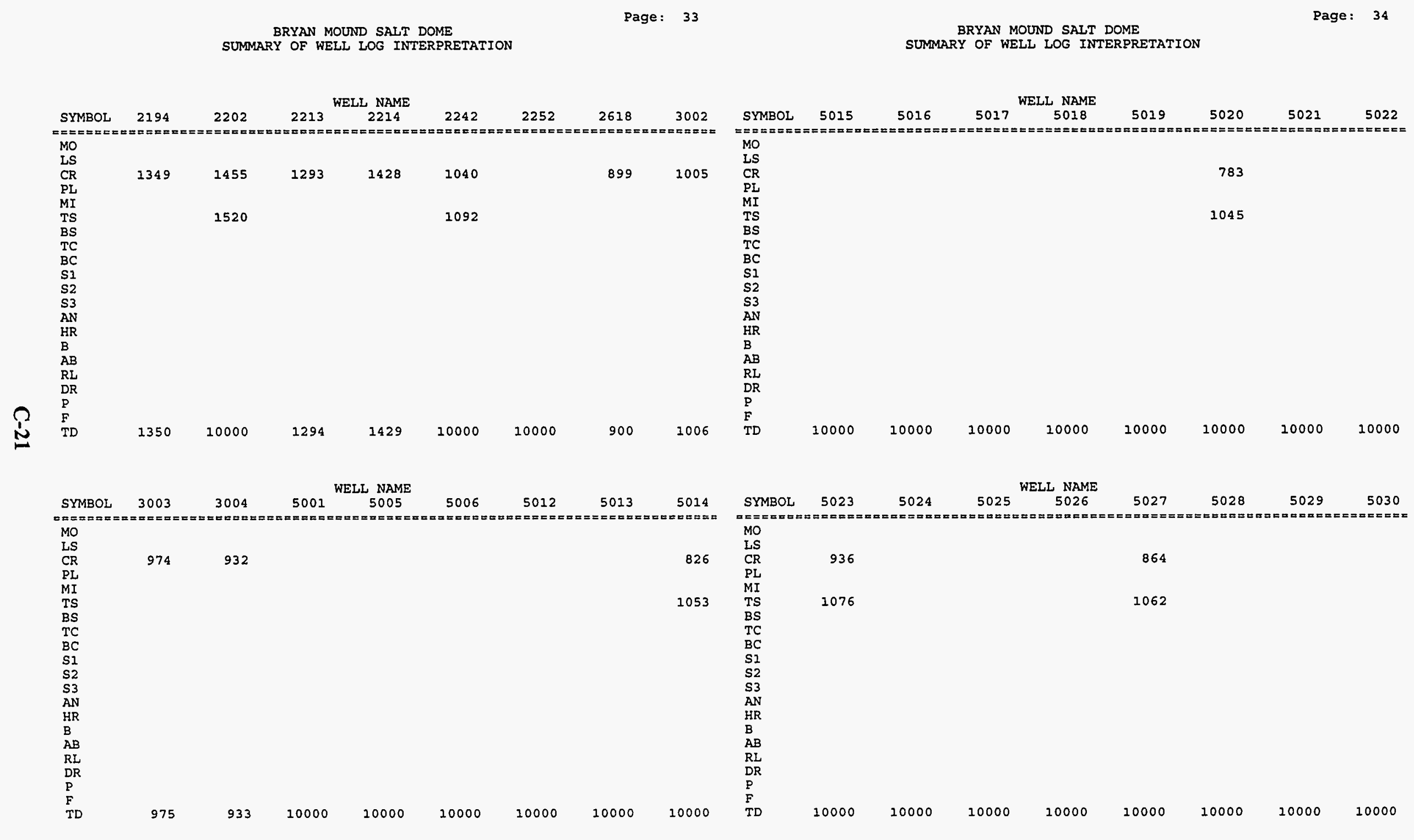


BRYAN MOUND SALT DOME

Page: 35 SUMMARY OF WELL LOG INTERPRETATION
BRYAN MOUND SALT DOME

SUMMARY OF WELL LOG INTERPRETATION

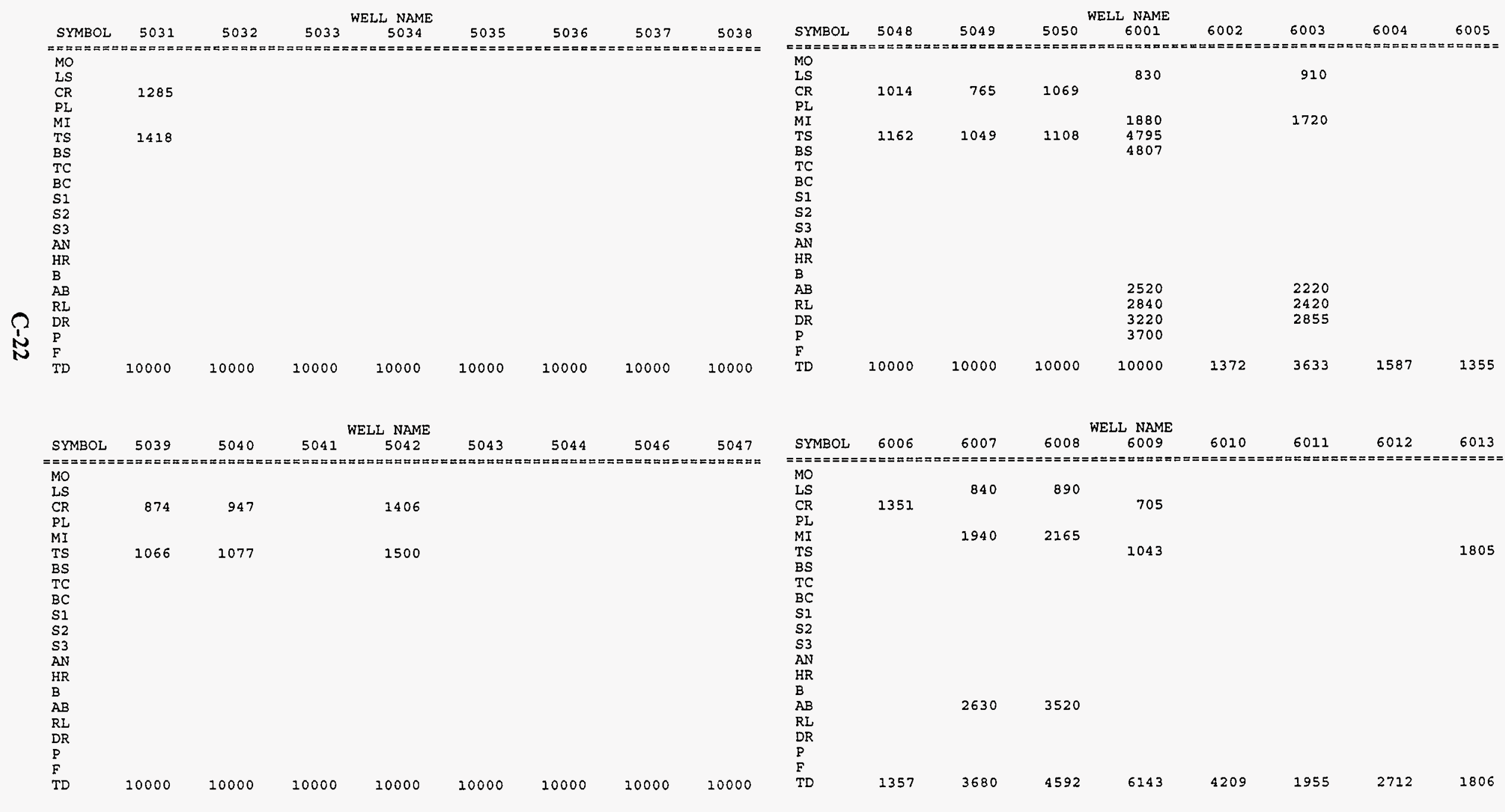




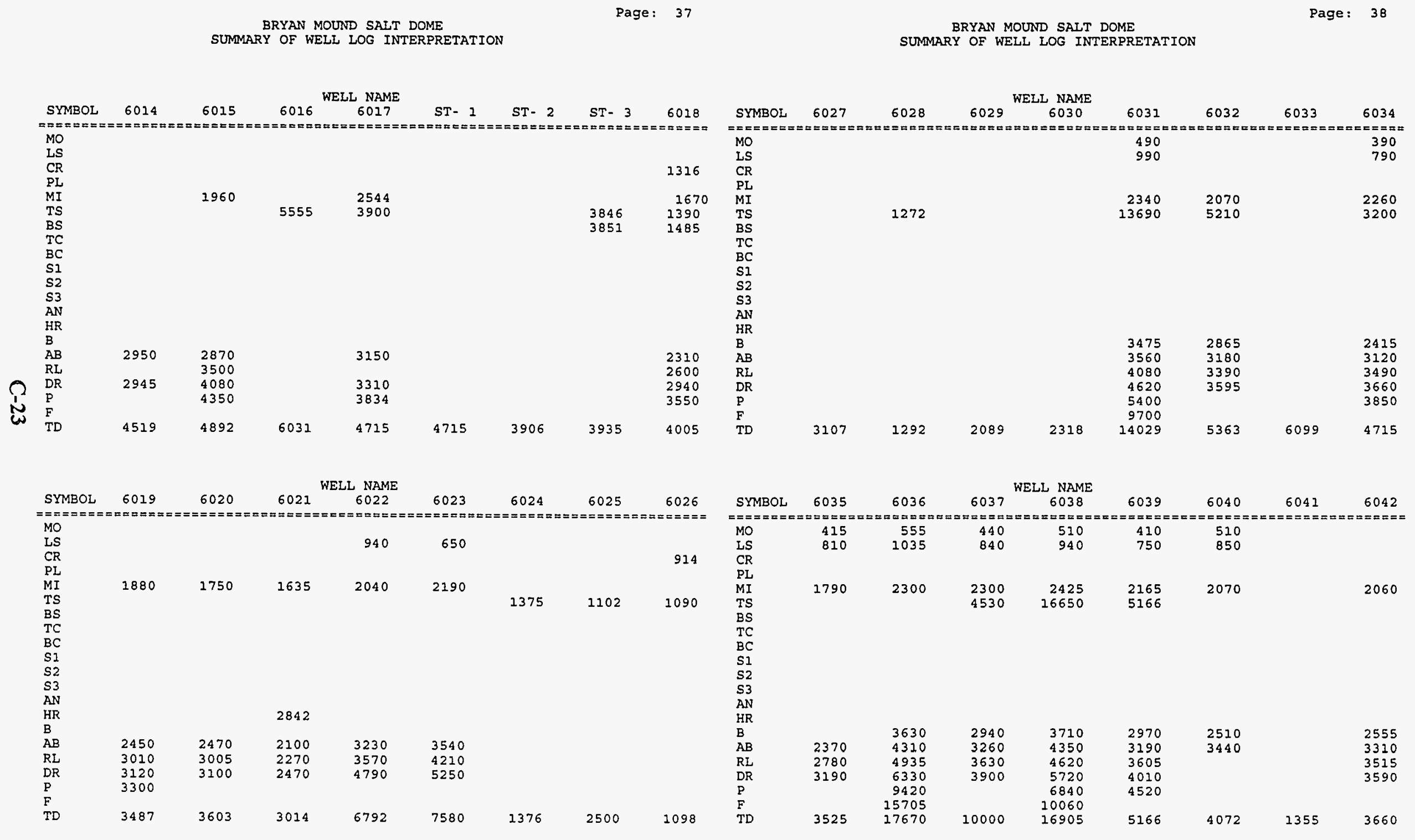


BRYAN MOUND SALT DOME

SUMMARY OF WELL LOG INTERPRETATION
Page: $\quad 39$

BRYAN MOURD SAIT DOME

SUMMARY OF WELL LOG INTERPRETATION
Page: 40

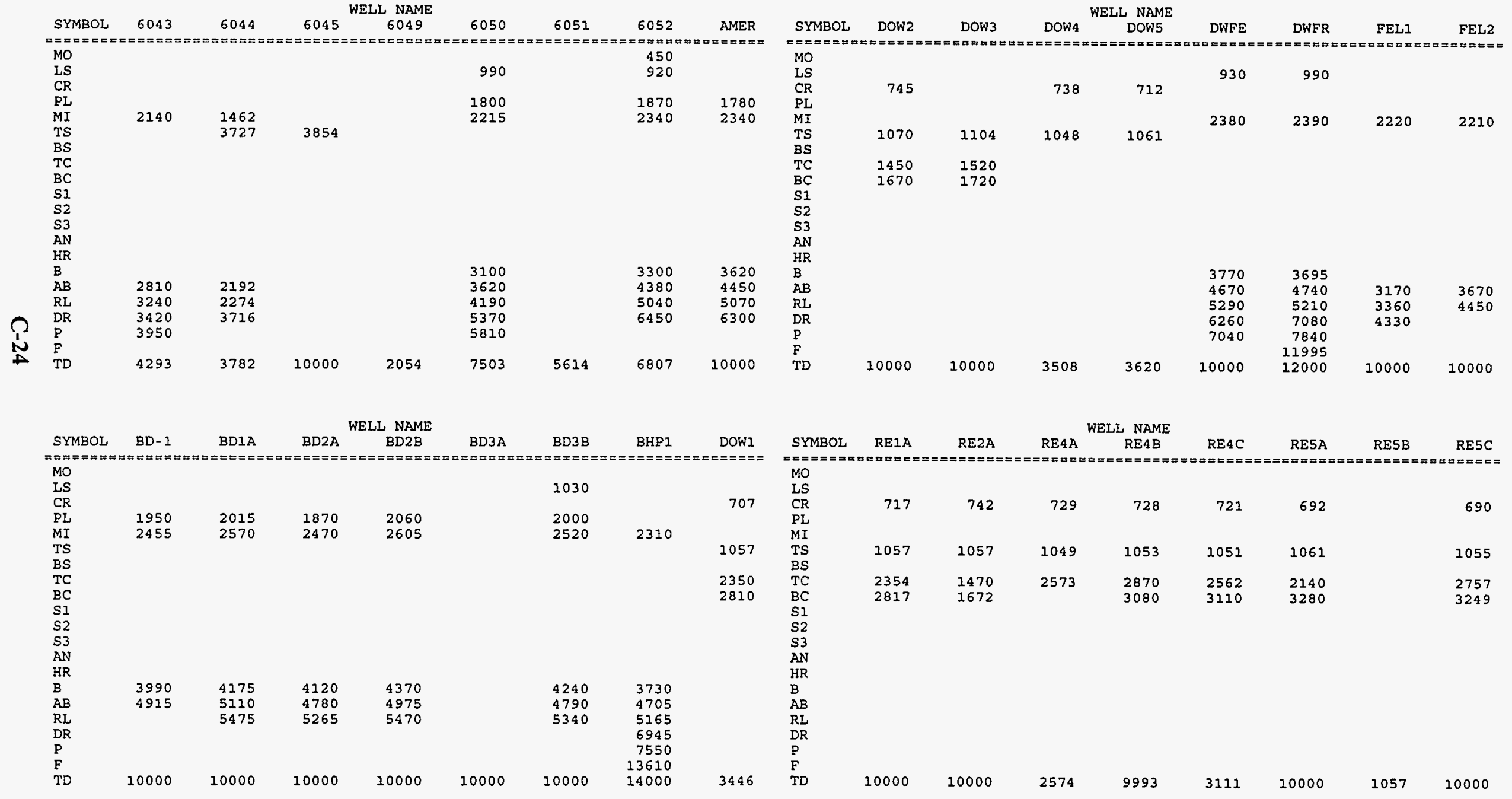




\section{APPENDIX D}

Selected Core and Thin Section Photographs

D-1 


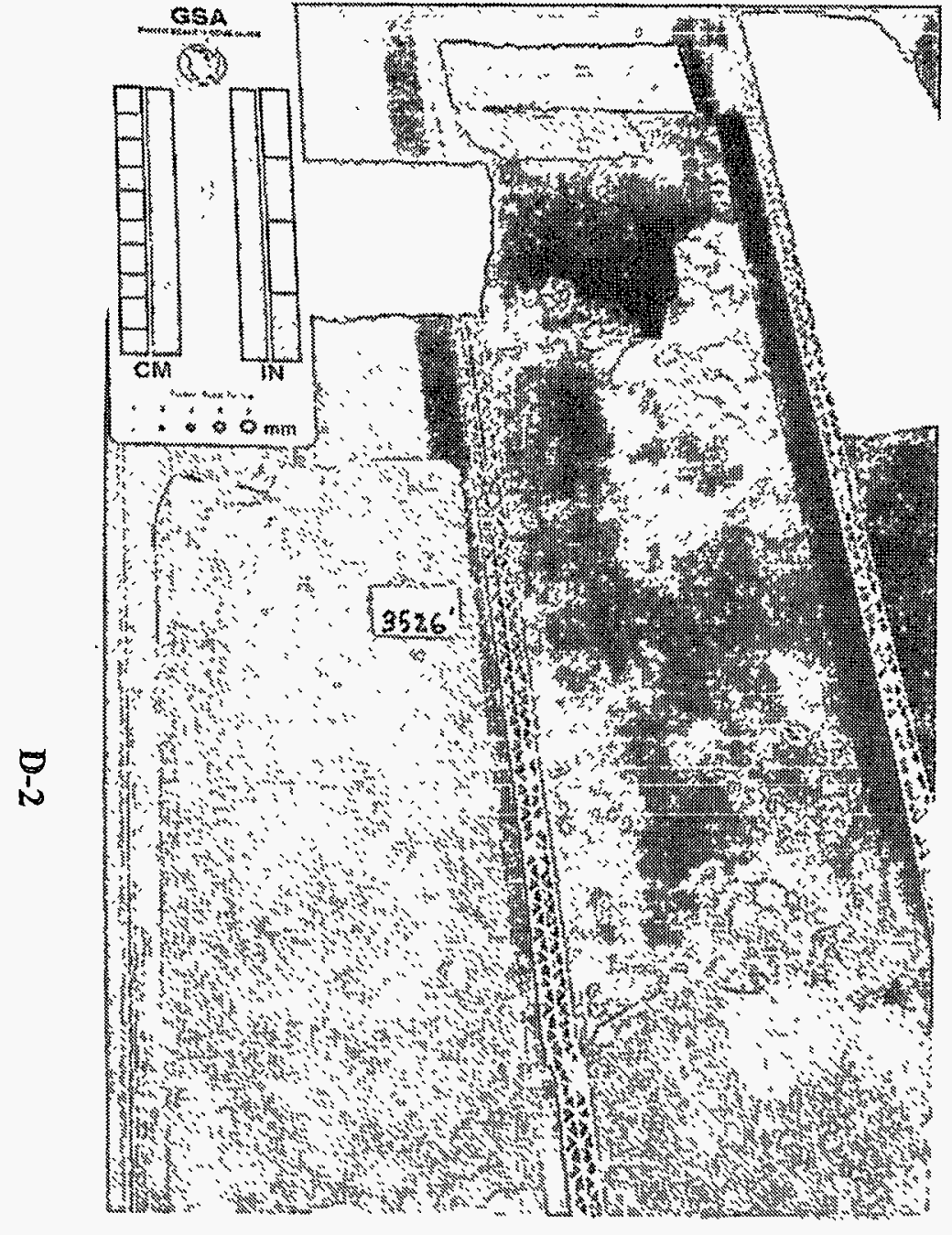

Figure D-1 A range of salt variations and crystallinity occurs within single caverns, e. g., 110 shown here in halved 4 " core specimens: $2663^{\prime}$ (u. right), black, and very finely $\left(\sim 0.25^{\prime \prime}\right)$ crystalline; 3526' (left), translucent "optical quality" single crystal; 4160' (1. right), equigranular uniform crystals, $\sim 0.5^{\prime \prime}$ average.
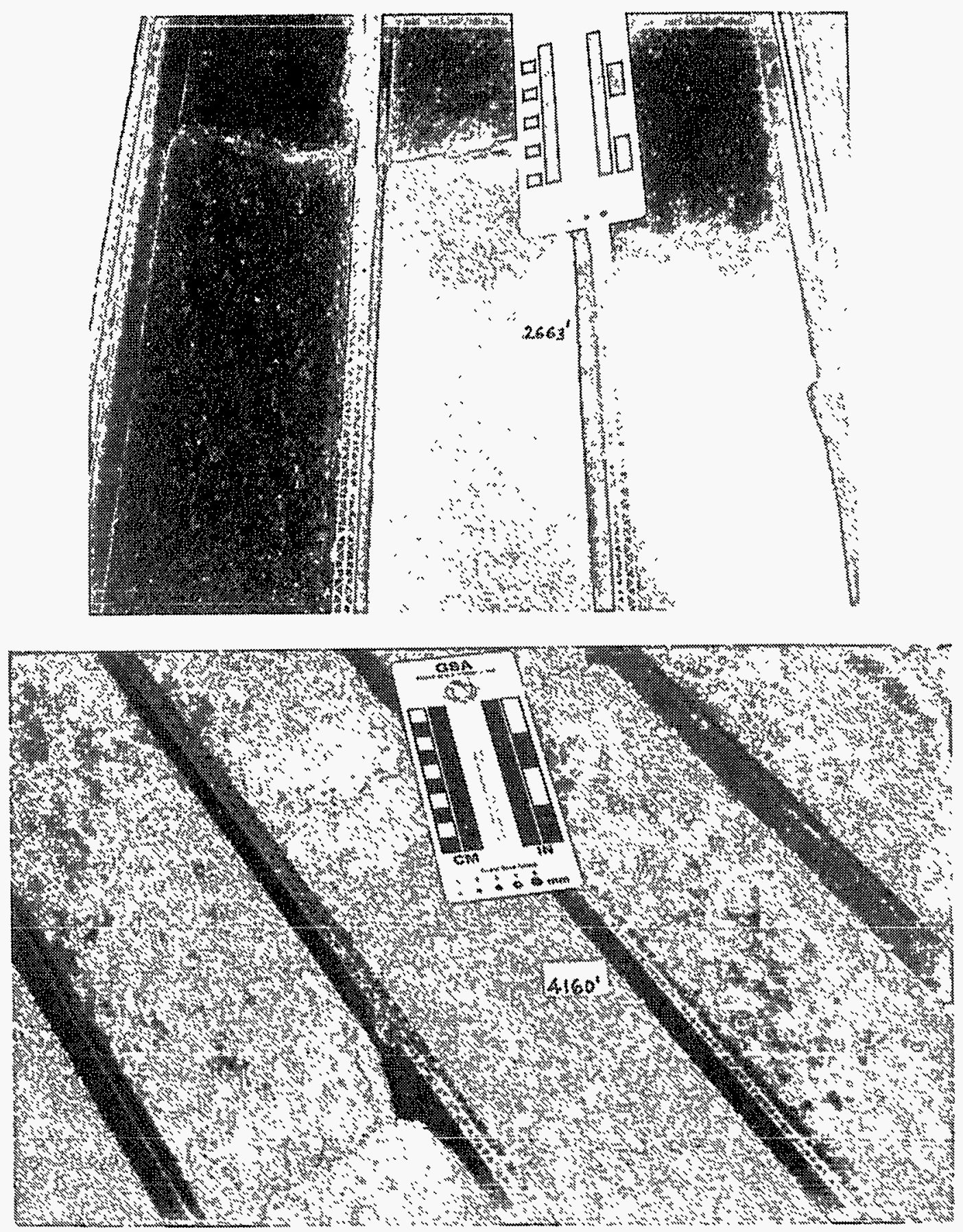


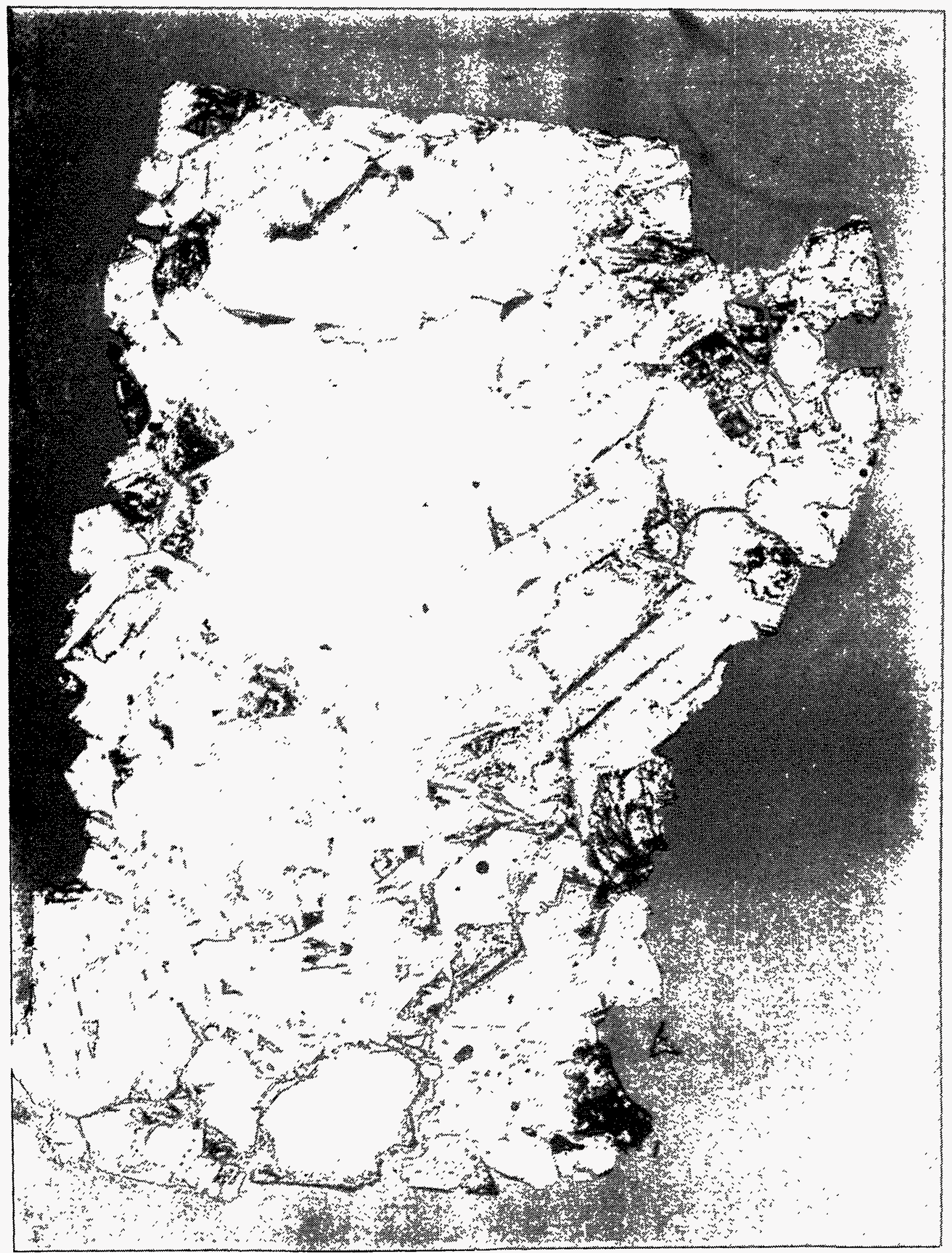

Figure D-2 Coarse-grained salt with black shale bands and minor anhydrite @3761', Cavern 110B. Magnification X 10.13 


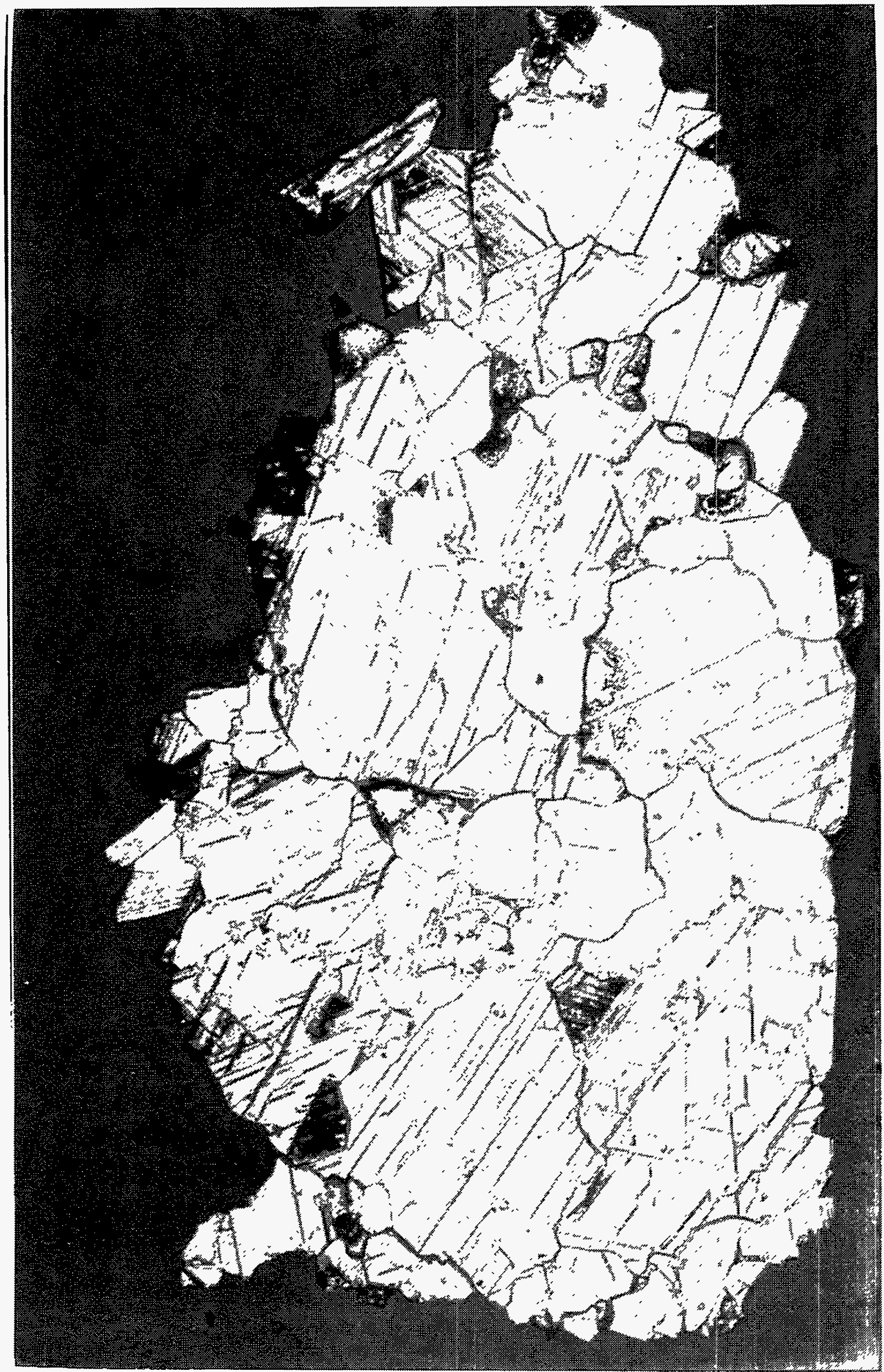

Figure D-3 Coarse-grained salt with minor black shale @3767', Cavern 110B. Magnification X 9.03 


\section{Distribution:}

U.S. DOE SPR PMO (10)

900 Commerce Road East

New Orleans, LA 70123

Attn: J. C. Kilroy, FE-443

J. Culbert, FE-4431

J. W. Kunkel, FE-4422

R. E. Myers, FE-4422 (3)

L. J. Rousseau, FE-433

M. W. Smith, FE-4441

TDCS (2)

U.S. Department of Energy (3)

Strategic Petroleum Reserve

1000 Independence Avenue SW

Washington, D.C. 20585

Attn: D. Johnson

D. Buck

H. Giles

DynMcDermott Petroleum Operations (5)

850 South Clearview Parkway

New Orleans, La 70123

Attn: K. Mills (3)

J. McHenry

J. Teerling

Bayou Choctaw SPR Site

60825 Hwy. 1148

Plaquemine, LA 70764

Attn: F. Tablada

Big Hill SPR Site

P. O. Box 1270

Winnie, TX 77665

Attn: Jim Perry

Bryan Mound SPR Site (5)

P.O. Box 2276

Freeport, TX 77541

Attn: C. Bellam (2)

H. Bakhtiari (2)

W. Denton

Wecks Island SPR Site

P.O. Box 434

New Iberia, LA 70560

Attn: M. Bertoldi
West Hackberry SPR Site

1450 Black Lake Road

Hackberry, LA 70645

Attn: P. Hetznecker

Joe L. Ratigan

$\mathrm{RE} / \mathrm{SPEC}$, Inc.

3824 Jet Drive

Rapid City, SD 57709

Rudy Begault

The MITRE Corporation

800 Commerce Road East, Suite 201

New Orleans, LA 70123

Richard Ginn

Underground Injection Control

Railroad Commission of Texas

Austin, TX 78711-2967

Ben Knape

Texas Water Commission

1700 N. Congress Ave.

P. O. Box 13087, Capitol Station

Austin, TX 79811

Injection and Mining Division (Bill Walter)

Louisiana Office of Conservation

P.O. Box 94275, Capitol Station

Baton Rouge, LA 70804-9275

Acres International Corporation (3)

140 John James Audubon Parkway

Amherst, NY 14228-1180

Attn: S. Thompson (2)

$$
\text { S. Ahmad }
$$

PB-KBB Inc. (2)

11767 Katy Freeway

P.O. Box 19672

Houston, TX 77224

Attn: Karl M. Looff

B. E. Russell

Texas Bureau of Economic Geology (3)

Univesity Station, Box X

Austin, TX 78713

Attn: W. L. Fisher

M.P.A. Jackson

S. J. Seni 
Howard W. Fiedelman

Solution Mining Research Institute

812 Muriel Street

Woodstock, IL 60098

Institute for Environmental Studies / Prof. W. Autin Louisiana State University

Baton Rouge, LA 70803

Louisiana Geological Survey(2)

University Station; Box G

Baton Rouge, LA 70893

Attn: C. G. Groat

Bridgid Jensen

Dr. Thomas R. Magorian (5)

133South Drive

Amherst, NY 14226-4119

R. L. Thoms (2)

AGM, Inc.

P.O. Box 10358

College Station, TX 77842
D. H. Kupfer

7324 Menlo Drive \#3

Baton Rouge, LA 70808

Joseph D. Martinez

3641 S. Lakeshore Drive

Baton Rouge, LA 70808

Sandia Internal:

6000 (MS 0724) D. L. Hartley

6100 (MS 0701) R. W. Lynch

6117 (MS 0751) W. R. Wawersik

6117 (MS 0751) D. S. Preece

6113 (MS 0706) J. K. Linn (10)

6113 (MS 0706) B. Eghartner

6113 (MS 0706) T. Hinkebein

6113 (MS 0706) P. Kuhlman

6113 (MS0706) J. L. Todd

6113 (MS 0706) S. J. Bauer

6113 (MS 0706) R.W. Ostensen

6113 (MS 0706) J. T. Neal (15)

7613-2 (MS 0100) Document Processing (for DOE/OSTI) (10)

8523-2 (MS 9018) Central Technical Files

13414 (MS 0899) Technical Library (5)

13416 (MS 0619) Technical Publications 